\title{
Household Energy \\ Conservation Attitudes and Behaviors in the Northwest: Tracking Changes Between 1983 and 1985
}
J. M. Fang
R. T. Nordi
M. P. Hattrup
S. A. Shankle
D. L. Ivey, Project Manager

May 1987

Prepared for the

Bonneville Power Administration

Office of Conservation

under a Related Services Agreement

with the U.S. Department of Energy

Contract DE-AC06-76RLO 1830

Pacific Northwest Laboratory

Operated for the U.S. Department of Energy

by Battelle Memorial Institute 


\title{
DISCLAIMER
}

This report was prepared as an account of work sponsored by an agency of the United States Government. Neither the United States Government nor any agency thereof, nor Battelle Memorial Institute, nor any of their employees, makes any warranty, expressed or implied, or assumes any legal liability or responsibility for the accuracy, completeness, or usefulness of any information, apparatus, product, or process disclosed, or represents that its use would not infringe privately owned rights. Reference herein to any specific commercial product, process, or service by trade name, trademark, manufacturer, or otherwise, does not necessarily constitute or imply its endorsement, recommendation, or favoring by the United States Government of any agency thereof, or Battelle Memorial Institute. The views and opinions of authors expressed herein do not necessarly state or reflect those of the United States Government or any agency thereof, or Battelle Memorial Institute.

\author{
PACIFIC NORTHWEST LABORATORY \\ operated by \\ BATTELLE MEMORIAL INSTITUTE \\ for the \\ UNITED STATES DEPARTMENT OF ENERGY \\ under Contract DE-AC06-76RLO 1830
}

Printed in the United States of America
Available from
National Technical Information Service
United States Department of Commerce
5285 Port Royal Road
Springfield, Virginia 22161
NTiS Price Codes
Microfiche A01
Printed Copy
Pages
$001-025$
$026-050$
$051-075$
$076-100$


HOUSEHOLD ENERGY CONSERVATION ATTITUDES

AND BEHAVIORS IN THE NORTHWEST: TRACKING

CHANGES BETWEEN 1983 and 1985
J. M. Fang
M. P. Hattrup
R. T. Nordi
S. A. Shankle
D. L. Ivey, Project Manager

May 1987

\author{
Prepared for the \\ Bonneville Power Administration \\ Office of Conservation \\ under a Related Services Agreement \\ with the U.S. Department of Energy \\ Contract DE-AC06-76RLO 1830
}

Pacific Northwest Laboratory

Richland, Washington 99352 


\section{PREFACE}

In October and November, 1985 a telephone survey of 1058 households in the Pacific Northwest was conducted as part of a project to analyze the marketing environment for conservation activities of the Bonneville Power Administration $(B P A)$. Analyses of the survey results are being published in a series of five reports:

- a tracking report analyzing the changes between 1983 and 1985

- a consumer characterization and segmentation report with detailed analyses of market segments

- a fuel switching report detailing the changes in primary and secondary fuel sources in home heating

- a financing report focusing on the financing aspects of household energy conservation investments

- a utility summary report presenting a summary of the above four reports with an emphasis on electrical utilities.

The work on this series of reports is conducted by Pacific Northwest Laboratory (PNL) in support of BPA's efforts to develop the capability in delivering conservation programs for use in the future when it becomes necessary to acquire conservation resources. BPA's technical monitor for the project has been Terry 0liver, Office of Conservation.

This report, entitled Household Energy Conservation Attitudes and Behaviors in the Northwest: Tracking Changes Between 1983 and 1985, PNL-5892, is the first report in the series. It covers aspects such as consumer perceptions of energy conservation, perceptions of institutions, energy conservation actions, and segmentation of consumers into three market prospect groups. The focus of the report is the comparison of the 1985 survey results with those of a similar survey conducted in late 1983. 
Comments and suggestions on this report are welcome. Please direct your correspondence to Pacific Northwest Laboratory, P.0. Box 999, Richland, Washington 99352.

D. L. Ivey

Project Manager 


\section{EXECUTIVE SUMMARY}

Pacific Northwest Laboratory (PNL) has analyzed the changes in consumer energy conservation attitudes and behaviors in the Pacific Northwest between 1983 and 1985. The information was collected through stratified random telephone surveys on 2,000 and 1,058 households, respectively, for 1983 and 1985 in the Bonneville Power Administration (BPA) service area in Idaho, Oregon, Washington and Western Montana. This information will be used by BPA to facilitate better conservation program planning, design, and marketing.

\section{COVERAGE AND HYPOTHESES}

This report covers four topic areas and tests two hypotheses. The topics are as follows:

- consumer perceptions and attitudes of energy use and conservation in the home

- consumer perceptions of energy institutions and other entities

- past and intended conservation actions and investments

- segmentation of homeowners into market prospect groups The hypotheses tested are as follows:

- There has been no change in the size and psychographic make-up of the original three market segments found in the 1983 survey analysis.

- Image profiles of institutions with respect to familiarity, overall impression, and believability as sources of energy conservation information remain unchanged since 1983.

In the following sections, major findings of the study are presented first. Some implications of the findings are then summarized. 


\section{PERCEPTIONS OF ENERGY CONSERVATION}

- Between 1983 and 1985, consumers in the Northwest have increasingly viewed energy conservation as using energy intelligently or effectively. In $1985,40 \%$ of the respondents defined energy conservation in such terms, compared with $8 \%$ in 1983.

- Psychographically, consumers were more likely in 1985 than in 1983 to agree with statements reflecting social responsibility, self interest, materialism, and lifestyle. Similarly, they were less likely in 1985 than in 1983 to agree with statements reflecting limits to energy conservation, cynicism or negative views on energy conservation.

The above results suggest that there was improved understanding of the nature of energy conservation over the two-year period. They also suggest that there was some internalization of energy conservation consciousness: consumers are becoming more energy conservation conscious.

- However, between 1983 and 1985, the intensity of concern about energy use in the home, cost of energy, and energy conservation declined, paralleling the declining trend in the intensity of concern about issues such as unemployment, inflation, and the environment. This may have been a result of changes in external conditions such as the power surplus increasingly being reported in the news media and the relatively more stable or declining energy prices.

- Although consumers in the Northwest were concerned about energy conservation and energy use in the home, the intensity of such concern was not as strong as that for other issues.

\section{PERCEPTIONS OF INSTITUTIONS}

- In 1985 as in 1983, the local electric utility stood out as the most familiar energy institution to consumers in the Northwest. When measured in terms of all consumers who were familiar with the energy institutions, energy extension service and the local electric utility were perceived to be the most concerned about the consumer. 
- In both years, the local electric utility was regarded as responsible for setting electricity prices, together with institutions such as BPA and the public utility commission.

- In terms of overall impressions, the energy extension service and the local electric utility were the two most favorably regarded energy institutions by consumers who were familiar with them. Radio and retail stores were the two most highly regarded nonenergy entities.

- The energy extension service, state energy office, the local electric utility, retail stores and the radio were the most credible sources of energy conservation information.

- Between 1983 and 1985, consumers familiarity with energy institutions generally increased; whereas favorability ratings of energy institutions remained relatively constant except for the Northwest Power Planning Council. For the latter, its favorability rating increased.

- In 1985 proportions of respondents who regarded the energy institutions, other entities and individuals as credible sources of energy conservation information were generally lower than in 1983, except for energy extension service, retail stores and news media. The believability rating of the latter three entities remained constant. It can be concluded from the above results that there have been significant changes between 1983 and 1985 in consumers' image profiles of energy institutions.

\section{ENERGY CONSERVATION BEHAVIORS}

- Only one significant change occurred in the proportions of consumers preferring a general approach to conserve energy in the home: the proportion of consumers who would both change their ways of living and spend money on improvements declined. 
- Most of the proportions for no/low cost energy conservation practices appeared to stay about the same or at a slightly lower level in 1985 than in 1983. The only action showing a significant increase was that of setting the thermostat at a lower level during the heating season.

- Five energy conservation measures (ECMs) showed increases in the proportion of homes equipped with them:

- roof/ceiling insulation

- wall insulation

- weatherproofing

- storm windows

- clock or setback thermostat.

- The proportions of homes equipped with following two ECMs stayed relatively unchanged during 1983-85:

- floor/basement/crawl space insulation

- heat pump furnaces.

- Showing declines in the proportions of homes equipped were the following two ECMs:

- storm doors

- wood stoves.

- It appeared that the proportions of homeowners who claimed to have actually installed specific ECMs during 1983-85 closely matched the proportions of those who indicated in 1983 that they were likely to invest in the ECMs in the next one or two years.

- Average investment per household in energy conservation amounted to about $\$ 1,570$ during 1983-85. This is slightly higher than the amount of $\$ 1,200$ during $1981-83$.(a)

(a) The average investment in the 1983 survey was about $\$ 1,800$. However, the figure was calculated for a period of three years. For comparison purposes, the figure shown in the text has been converted into a corresponding 2-year figure by multiplying the original figure by the ratio of $2 / 3$. 
- In 1985, homeowners who had made investments in ECMs speculated that the value of their home would increase by $110 \%$ of their investments compared with the 160\% increase derived in the 1983 survey.

- Perceived average savings in monthly electrical bills was estimated at $\$ 55$ in the 1985 survey, compared with $\$ 32$ in the 1983 survey.

- Current income, savings, bank and utility loans, and utility payments, in that order, were the most important sources of financing energy conservation investments in 1985, as in 1983.

- The proportion of homes not equipped with a specific ECM but whose owners indicated that they were likely to install the ECMs into the next two years ranged from 3 to 15\% in 1985, compared with 6 to $13 \%$ in 1983. (a)

\section{MARKET PROSPECT GROUPS}

As in the 1983 survey, homeowners were segmented into three prospect groups likely to invest in ECMs based on past investment behaviors and expressed intent to invest:

- The size distribution of the prospect groups in 1985 remained relatively unchanged from that in 1983.

- First-tier prospects, including those who were considered to be most likely to invest in ECMs, accounted for about 1 in 10 households in the region.

- Second-tier prospects, covering those who were considered to be somewhat likely to invest in ECMs, amounted to be about 1 in 3 households.

- Nonprospects, those who are unlikely to invest in ECMs on their own were estimated to be about 1 in 3 households.

- About 1 in 4 of the region's households were renters and were

- not included in the above prospect groups.

(a) As a proportion of total homeowners. 
- In 1985, there were some changes in the psychographic profiles of prospect groups in the sense that significantly larger proportions of respondents agreed with the following statements, compared to those observed in 1983:

Statements Reflecting Social Responsibility "Conserving energy is the best way to protect the environment." Statements Reflecting Self Interest/Materialism/Lifestyle "Most people who conserve electricity do so to save money." "Conserving energy is the best way to maintaining my lifestyle."

Statements Reflecting Cynicism/Negative Views on Energy Conservation "The amount of energy I use is really my own affair and no one else's."

In contrast, the proportion decreased regarding respondents who agreed with the statement that "my conservation efforts won't have much effect one way or the other on the availability of electricity" (a statement reflecting cynicism/negative views on energy conservation).

The proportions of respondents who agreed with the other statements remain unchanged.

\section{IMPL ICATIONS}

- With improved understanding of energy conservation and heightened level of energy conservation consciousness on the part of the consumers in the region, it would be useful to explore the ways to tap them. This can be included as part of the overall effort in building the capability to deliver conservation programs. This capability would be used to acquire conservation resources at the time when they are needed.

- The lower level of concern for energy conservation and related issues in 1985 reflected mainly the impact of changed external conditions. In addition, the intensity of concern for energy conservation and energy use was lower than that for other issues such as crime, unemployment, inflation, and the environment. These results suggest 
that public awareness and information programs should continue to play an important role in the effort to promote energy conservation.

- Given the high favorability and credibility ratings of the energy extension service, the local electric utility, the news media and the retail stores, as well as the high credibility of the state energy office in terms of energy conservation information, efforts to reach consumers should include as intermediaries, the energy extension service, the electric utility, the state energy office, the news media, and the retail stores.

- It is well known that a period of power surplus currently exists in the Northwest. Therefore, the general strategy is to build the capability to acquire conservation resources for application when the need arises, rather than actually acquire them at this time. This strategy would require different approaches for different prospect groups:

- For the First-tier and Second-tier prospects, the approach should be one of maintenance through promotional efforts such as public information programs, especially by providing information about the benefits of specific ECMs. Few subsidies or none at all would be used for the duration of the power surplus.

- For the Nonprospects, the approach should be to actively develop this group into Second-tier and eventually first-tier prospect groups. The goal of this approach would be to increase awareness and interest in specific ECMs and to persuade consumers to invest in their ECMs, at least at a minimal level. Because Nonprospects are likely to be low income households, some subsidies may be necessary, even during the period of power surplus. 


\section{CONTENTS}

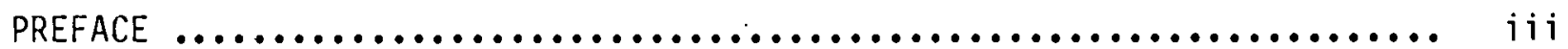

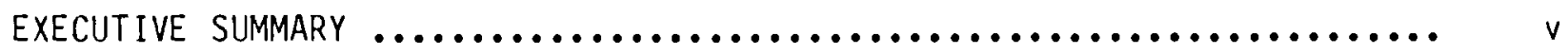

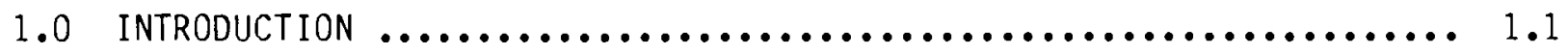

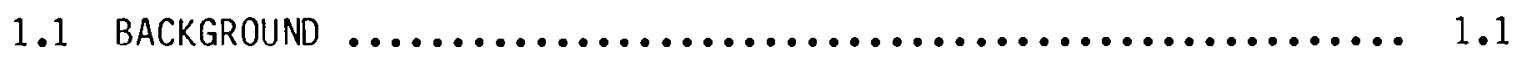

1.2 SURVEY AND SAMPLE DESCRIPTIONS $\ldots \ldots \ldots \ldots \ldots \ldots \ldots \ldots \ldots \ldots . . \ldots \ldots$

1.3 SCOPE AND LIMITATIONS OF THE REPORT $\ldots \ldots \ldots \ldots \ldots \ldots \ldots \ldots, 1.5$

1.4 REPORT CONTENTS $\ldots \ldots \ldots \ldots \ldots \ldots \ldots \ldots \ldots \ldots \ldots \ldots \ldots \ldots \ldots, 1.6$

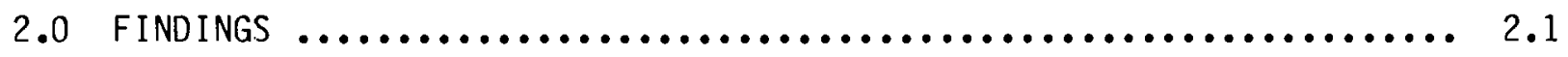

2.1 CONSUMER PERCEPTIONS OF ENERGY CONSERVATION $\ldots \ldots \ldots \ldots \ldots \ldots . . . .1$

2.2 PERCEPTiONS OF InStitutions $\ldots \ldots \ldots \ldots \ldots \ldots \ldots \ldots \ldots \ldots \ldots \ldots \ldots \ldots \ldots$

2.3 ENERGY CONSERVATION ACTIONS $\ldots \ldots \ldots \ldots \ldots \ldots \ldots \ldots \ldots \ldots \ldots \ldots \ldots \ldots \ldots$

2.4 MARKET PROSPECT GROUPS $\ldots \ldots \ldots \ldots \ldots \ldots \ldots \ldots \ldots \ldots \ldots \ldots \ldots \ldots, 2.9$

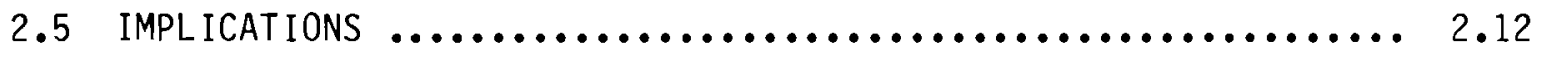

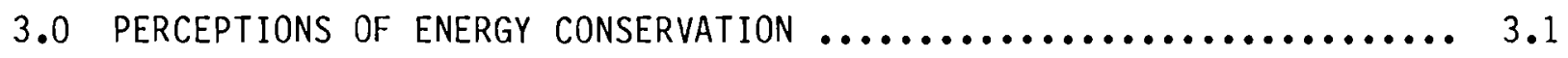

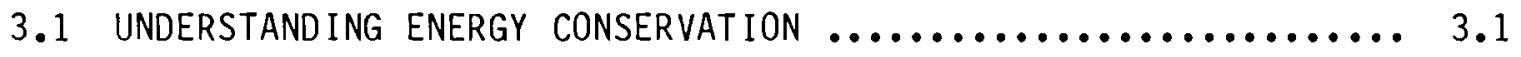

3.2 CONCERN ABOUt ENERGY CONSERVATION AND OTHER ISSUES $\ldots \ldots \ldots \ldots .3 .4$

3.3 ATTITUDES TOWARD ENERGY USE AND CONSERVATION $\ldots \ldots \ldots \ldots \ldots \ldots . .7$

4.0 PERCEPTIONS OF INSTITUTIONS $\ldots \ldots \ldots \ldots \ldots \ldots \ldots \ldots \ldots \ldots \ldots \ldots \ldots . \ldots . \ldots \ldots$

4.1 FAMILIARITY WITH ENERGY INSTITUTIONS $\ldots \ldots \ldots \ldots \ldots \ldots \ldots \ldots . . . . . .1$

4.2 CONCERN FOR THE CONSUMER $\ldots \ldots \ldots \ldots \ldots \ldots \ldots \ldots \ldots \ldots \ldots \ldots . . .2$

4.3 RESPONSIBILITY FOR ELECTRICITY PRICES $\ldots \ldots \ldots \ldots \ldots \ldots \ldots \ldots . .3$

4.4 OVERALL IMPRESSIONS $\ldots \ldots \ldots \ldots \ldots \ldots \ldots \ldots \ldots \ldots \ldots \ldots \ldots \ldots \ldots, 4.4$

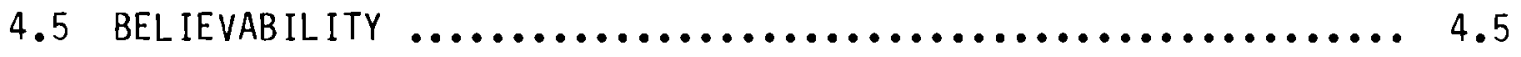

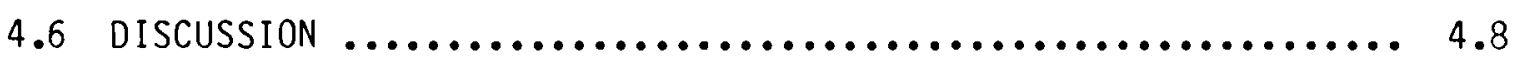


5.0 ENERGY CONSERVATION ACTIONS $\ldots \ldots \ldots \ldots \ldots \ldots \ldots \ldots \ldots \ldots \ldots \ldots \ldots . . . \ldots \ldots$

5.1 PREFERRED METHODS FOR CONSERVING ENERGY $\ldots \ldots \ldots \ldots \ldots \ldots \ldots \ldots . . \ldots \ldots$

5.2 NO/LOW COST CONSERVATION PRACTICES $\ldots \ldots \ldots \ldots \ldots \ldots \ldots \ldots \ldots . .2$

5.3 ENERgy CONSERVATION INVESTMEnTS $\ldots \ldots \ldots \ldots \ldots \ldots \ldots \ldots \ldots \ldots . .4$

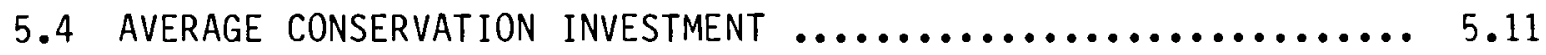

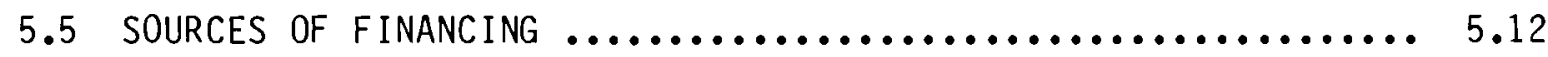

5.6 LiKely futURE CONSERVATION INVESTMENT $\ldots \ldots \ldots \ldots \ldots \ldots \ldots \ldots . \ldots \ldots$

5.7 IMPACTS OF CONSERVATION INVESTMENT $\ldots \ldots \ldots \ldots \ldots \ldots \ldots \ldots \ldots . \ldots . \ldots . \ldots . \ldots$

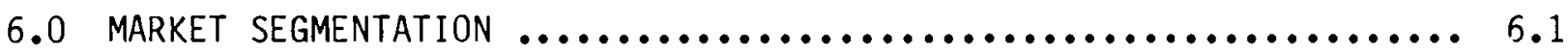

6.1 DEFINING MARKET SEGMENTS AND PROSPECT GROUPS $\ldots \ldots \ldots \ldots \ldots \ldots . . \ldots .1$

6.2 DEMOGRAPHICS AND ENERGY USE CHARACTERISTICS $\ldots \ldots \ldots \ldots \ldots \ldots . . .4$

6.3 ATTITUDES TOWARDS ENERGY CONSERVATION OF PROSPECT GROUPS $\ldots . . .6 .7$

6.3.1 Concern About Various Issues $. . \ldots \ldots \ldots \ldots \ldots \ldots . . .6 .6$

6.3.2 Psychographic Profiles ........................ 6.9

6.4 PERCEPTIONS OF INSTITUTIONS OF PROSPECT GROUPS $\ldots \ldots \ldots \ldots \ldots \ldots . \ldots \ldots$

6.4 .1 0verall Impressions $\ldots \ldots \ldots \ldots \ldots \ldots \ldots \ldots \ldots \ldots \ldots, 6.13$

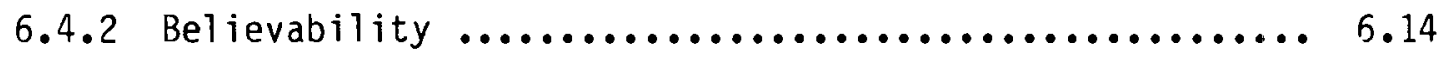

6.5 ENERGY CONSERVATION ACTIONS OF PROSPECT GROUPS $\ldots \ldots \ldots \ldots \ldots . .6 .17$

6.5.1 Preferred Methods for Conserving Energy $\ldots \ldots \ldots \ldots \ldots .6 .17$

6.5.2 No/Low Cost Energy Conservation Actions ............ 6.18

6.5.3 Investment-Type Energy Conservation Measures ........ 6.19

6.6 FINANCING SOURCES OF PROSPECT GROUPS $\ldots \ldots \ldots \ldots \ldots \ldots \ldots \ldots . . \ldots .23$

6.7 LIKELY FUTURE ACTIONS OF PROSPECT GROUPS $\ldots \ldots \ldots \ldots \ldots \ldots \ldots, 6.23$

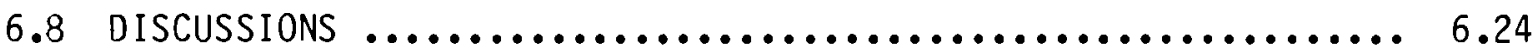


REFERENCES $\ldots \ldots \ldots \ldots \ldots \ldots \ldots \ldots \ldots \ldots \ldots \ldots \ldots \ldots \ldots \ldots \ldots \ldots \ldots \ldots \ldots \ldots \ldots \ldots \ldots$

APPENDIX A--TESTING THE SIGNIFICANCE OF DIFFERENCES BETWEEN TWO

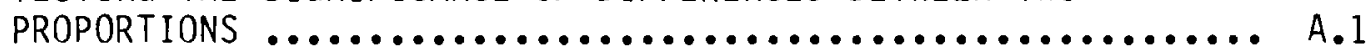

APPENDIX B--DETAILED 1985 DATA AND DISCUSSIONS $\ldots \ldots \ldots \ldots \ldots \ldots \ldots \ldots \ldots \ldots$ 


\section{FIGURES}

2.1 Segmentation of the Residential Energy Conservation Market ....... 2.10

6.1 Segmentation of the Residential Energy Conservation Market ....... 6.2

$\underline{\text { TABLES }}$

2.1 Psychographic Profile: Agreement. and Disagreement with

Statements, 1985 versus 1983 ............................ 2.4

3.1 Meaning of the Term "Energy Conservation" by Category,

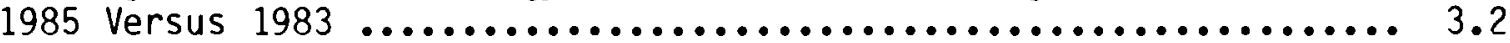

3.2 Specific Mentions in the Category of Conserve/Save Energy,

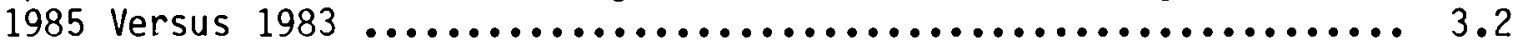

3.3 Concern About Specific Issues, 1985 Versus 1983 ............... 3.5

3.4 Psychographic Profiles: Agreement and Disagreement with Statements, 1985 ................................... 3.10

3.5 Psychographic Profile: Agreement and Disagreement with

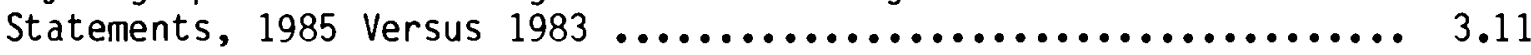

4.1 Proportions of Respondents Who Are Not Familiar with Energy Institutions, 1983 Versus $1985 \ldots \ldots \ldots \ldots \ldots \ldots \ldots \ldots \ldots \ldots \ldots \ldots \ldots \ldots . \ldots . \ldots . \ldots$

4.2 Perceptions of Energy Institutions' Concern for the Consumer, 1985 ....................................... 4.3

4.3 Overall Impressions of Energy Institutions, 1985 Versus 1983 ..... 4.4

4.4 Overall Impression of Other Entities and Individuals, $1985 \ldots \ldots . . .4 .5$

4.5 Believability of Institutions and Entities as Sources of Information About Energy Conservation, 1985 Versus 1983 ........ 4.6

5.1 Preferred Method of Conserving Energy, 1985 Versus 1983 ......... 5.1

5.2 Low Cost Energy Conservation Measures Regularly Used,

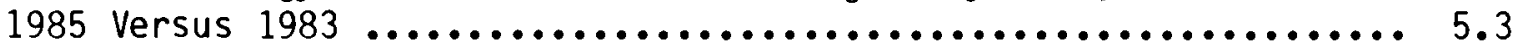

5.3 Proportions of Owner-Occupied Homes with Specific Energy Conservation Measures According to Time of Installation, 1985 
5.4 Proportions of Owner-Occupied Homes Currently Equipped with Specific Energy Conservation Measures, 1985 Versus 1983 ......... 5.7

5.5 Proportions of Owner-Occupied Homes for Which Specific ECMS are Installed Since Respondents Moved In, 1985 ............... 5.8

5.6 Proportions of Homeowners Installing Specific Energy Conservation Measures--Comparison Between Intention and Claimed Installation .......................................... 5.9

5.7 Average Conservation Investment, 1985 Versus 1983 ............. 5.11

5.8 Financing Sources for Energy Conservation Investment, 1985 Versus 1983

5.9 Likelihood of Installing Specific ECMs During the Next Two to Three Years, 1985 Versus 1983

5.10 Average Increases in Home Values Due to Energy Conservation Investment, 1985 Versus 1983

6.1 Distribution of Prospect Groups, 1985 Versus 1983 6.3

6.2 Concern About Various Issues by Prospect Groups, 1985 Versus 1983

6.3 Psychographical Images, 1985 Versus 1983

6.4 Overall Impression of Energy Institutions by Prospect Group: Comparison with 1983 Results

6.5 Believability of Energy Institutions as Sources of Energy Conservation Information by Prospect Group, 1985 Versus 1983

6.6 Believability of Other Entities and Individuals as Source of Energy Conservation Information by Prospect Group, 1985 Versus 1983

6.7 Preferred Methods for Conserving Energy by Prospect Group, 1985 Versus 1983

6.8 No/Low Cost Energy Conservation Actions by Prospect Group, 1985 Versus 1983

6.9 Proportions of Homes Equipped with Specific ECMs by Prospect Group, 1985 Versus 1983 
6.10 Sources of Financing Conservation Investment by Prospect

Group, 1985 Versus 1983 ................................. 6.23

6.11 Likely Installation of Energy Conservation Measures by Prospect Group, 1985 Versus 1983 


\section{$1.0 \quad$ INTRODUCTION}

This report presents information and analyses to track the changes, if any, in the energy conservation attitudes and behaviors of consumers in the Pacific Northwest between 1983 and 1985. The information was collected through random telephone surveys of households in Idaho, Oregon, Washington, and Western Montana. Pacific Northwest Laboratory (PNL) conducted analyses of the survey results for the Bonneville Power Administration (BPA) to obtain a better understanding of consumer attitudes and behaviors and to facilitate conservation program planning, design, and marketing.

\subsection{BACKGROUND}

During 1983-84, PNL conducted the Phase I study of consumer energy conservation attitudes for the BPA. The study was part of an overall project designed to assess the marketing environment for BPA's energy conservation programs and activities. It was the first comprehensive regional study of its kind and established a baseline for future tracking.

In the baseline study, a telephone survey of 2000 residents of the Northwest was conducted.(a) The sample was drawn to be a representative crosssection of consumers in the Northwest and was composed of 500 respondents from each of the four geographic divisions: Western Washington; Western Oregon; Eastern Oregon and Southern Idaho; Eastern Washington, Northern Idaho, and Western Montana. The respondents were adult heads of households. Only one respondent per household was interviewed. Eighty percent of the interviews were conducted during evening and weekend hours between october 30 and November 13, 1983. Seventy-five percent of the interviews lasted approximately 20 minutes. Interviews with the remaining respondents lasted approximately 30 minutes longer because of additional questions relating specifically to heat pump and solar water heaters.

The respondents were asked questions regarding their attitudes, perceptions, and awareness of energy conservation; their conservation actions and

(a) The survey was conducted by RMH Research Inc. of River Edge, New Jersey. 
measures to date; their methods of financing past conservation investments; their perceptions of energy institutions; their behaviors with respect to public communication media such as newspapers, radio and television; and their willingness to invest in energy conservation and its relationship to perceived rates of returns. Based upon their past investment in energy conservation measures, and excluding renters who accounted for about $24 \%$ of the region's households, three market prospect groups were identified:

- First-Tier Prospects were those homeowners who had previously installed eight or more specific energy conservation measures (ECMs). Homeowners in this group indicated an interest in investing in additional ECM requiring substantial capital. This group represented approximately $18 \%$ of the region's households.

- Second-Tier Prospects were those homeowners who had previously installed 2 to 7 ECMs. They were willing to invest in full weatherization of their homes. This market group accounted for about $22 \%$ of the region's households.

- Nonprospects were homeowners who had undertaken only one conservation measure or none at all. They showed little interest in adopting additional energy conservation measures. This segment represented $36 \%$ of the region's households.

The results of the baseline study (RHM Research, Inc. 1984a) were published and compared with results from other studies (Fang 1985). A companion survey on the marketing environment for solar and heat pump water heaters was al so conducted (RMH Research, Inc. 1984b).

In July 1985, PNL undertook Phase II of the project to analyze the marketing environment for BPA conservation activities with the following three objectives:

1. to track changes in consumer attitudes, interests and opinions between 1983 and 1985

2. to identify more refined segments of the residential conservation market in terms of attitudes, interests, and opinions 


\section{3. to test hypotheses concerning consumer conservation actions and}

investment behaviors.

To achieve these objectives, a second survey of Northwest consumers was conducted in late 1985. This report provides the data, information, and analyses to achieve Objective 1 and part of Objective 3 relating to tracking changes in attitudes. Specifically, it describes the 1985 attitudes, perceptions, and behaviors of the consumers and compares them with the 1983 survey results to identify the changes that are statistically significant. It also tests the following two hypotheses: a) There has been no change in the size and psychographic make-up of the original three market prospect groups from the 1983 survey described above; and b) the familiarity, overall impression, and believability as a source of energy information of energy institutions and other entities remained unchanged since 1983.

\subsection{SURVEY AND SAMPLE DESCRIPTIONS}

In the 1985 survey, 1058 telephone interviews were completed. The sample was drawn from Idaho, Oregon, Washington and Western Montana, with about equa 1 number of respondents from each of the same four geographical divisions as in the 1983 sample. Interviews were conducted from October 15 through November 8, 1985. Calls were made from $4 \mathrm{p} . \mathrm{m}$. to $9 \mathrm{p} . \mathrm{m}$. on weekdays and from 10:30 a.m. to 7 p.m. on Saturdays and Sundays. Each interview took between 35 and 45 minutes to complete. The refusal rate was $13 \%$ and the termination rate was $10 \%$ (a)

The data presented in this report have been weighted to approximate population values in the BPA service area. The populations of counties within each of the four geographic divisions in the BPA service area were determined and summed. This yielded a total population count for each geographic division. The total counts for the four geographic divisions were then summed to arrive at a total population for the BPA service area. The populations of each division were then expressed as a percentage of the total population of the

(a) For detailed description of sampling design, survey procedure, and survey instrument, see Columbia Research Center, 1985 Marketing Environment for BPA Conservation Activities: Phase II, Draft report submitted to Pacific Northwest Laboratory, December 6, 1985, Portland, Oregon. 
region. The weights were derived by comparing the sample observations for the geographic divisions with their respective divisional populations. All population values were approximated by using the 1980 Census data.(a)

The main focus of this report is the comparison of the conservation attitudes, actions, and perceptions exhibited in the two samples. However, there are differences in the demography of the two samples, which may affect the reliability of the comparison of attitudes, actions, and perceptions. These differences are noted below: (b)

- Compared with the 1983 sample, the 1985 sample is composed of a larger proportion of female respondents (62\% versus $54 \%$ ). This higher proportion of females in the 1985 sample may have affected the occupational characteristic of the sample, noted below.

- The 1985 sample has a significantly larger group of respondents whose occupation is in the "clerical-sales-technician" category ( $17 \%$ in the 1985 sample versus 7\% in the 1983 sample) and a smaller group in the "crafts-foreman" category (7\% versus $15 \%$ ).

(a) Total number of households in the Pacific Northwest for 1980 is $3,022,490$. The details of the weights by geographic division are as follows:

\begin{tabular}{|c|c|c|c|c|c|}
\hline $\begin{array}{c}\text { Geographic } \\
\text { Division }\end{array}$ & $\begin{array}{l}\text { Relative } \\
\text { Weight }\end{array}$ & $\begin{array}{l}\% \text { of Total } \\
\text { Households } \\
\end{array}$ & $\begin{array}{l}\text { Households } \\
\text { in Division }\end{array}$ & $\begin{array}{l}\text { Households } \\
\text { in Sample }\end{array}$ & $\begin{array}{c}\text { Weight for } \\
\text { Division } \\
\end{array}$ \\
\hline $\begin{array}{l}\text { W. Washington } \\
\text { W. Oregon } \\
\text { E. Washington, } \\
\text { N. Idaho, \& } \\
\text { W. Montana }\end{array}$ & $\begin{array}{l}1.58 \\
1.12 \\
0.73\end{array}$ & $\begin{array}{l}39.50 \\
20.80 \\
18.25\end{array}$ & $\begin{array}{r}1,193,884 \\
846,297 \\
551,604\end{array}$ & $\begin{array}{l}258 \\
270 \\
274\end{array}$ & $\begin{array}{l}4,627.5 \\
3,134.4 \\
2,013.2\end{array}$ \\
\hline $\begin{array}{l}\text { E. Oregon \& } \\
\text { S. Idaho }\end{array}$ & 0.57 & 14.25 & 430,705 & 256 & $1,682.4$ \\
\hline Total & 4.00 & 100.00 & $3,022,490$ & 1,058 & -- \\
\hline
\end{tabular}

(b) See Appendix Table B.1 for the detailed statistics of the comparison. 
- The 1985 sample has a larger group of single-person households (19\% versus $15 \%$ in 1983 ).

- The 1985 sample has twice as many respondents who have moved within the past year compared with those in the 1983 sample (23\% versus $10 \%)$.

- In the 1985 sample, fewer respondents have remained at their current addresses from one to four years (22\% versus $31 \%$ ).

- The 1985 sample has a larger group of higher income (over $\$ 30,000$ ) respondents than the 1983 sample (32\% versus $24 \%$ ).

- The proportion of renters in the 1985 sample is higher than that in the 1983 sample (29\% versus $24 \%$ ).

The two samples had no significant differences in other characteristics of education, age distribution, types of dwelling units, primary heating fuel, and number of persons in the household.

\subsection{SCOPE AND LIMITATIONS OF THE REPORT}

This report includes only those aspects of the 1985 survey that permit comparison with the 1983 survey results. It does not include all aspects covered in the 1985 survey; much of the information collected in the 1985 survey are being used for other analyses and will be presented in a series of separate reports on consumer characterization and segmentation, fuel switching, and financing.

To the extent possible, the comparisons between the two surveys are conducted in terms of standard statistical test of significance of differences between two proportions at the $95 \%$ confidence level. In the tables, values that are significantly greater than others are marked with an asterisk (*) and those which are significantly lower than others are marked with a tilde $(\sim)$ (a)

The proportions presented in this report are computed by including those respondents who indicated "don't know" or refused to answer a specific question in the total number of respondents. Therefore, it is different from the

(a) See Appendix A for a detailed description of the significance testing and explanation of the convention to denote the results of the test. 
proportions presented in the other reports in this series. This was done to ensure that the 1985 data would be comparable to the 1983 data. Exceptions are those associated with Chapter 4 on perceptions of energy institutions, in which the proportions are computed in terms of those who are familiar with the institutions only.

\subsection{REPORT CONTENTS}

Chapter 2 presents an overview of the findings and conclusions derived in the analyses detailed in Chapters 3 through 6 . Chapter 3 discusses consumer perceptions of energy conservation and related issues. Chapter 4 explains consumer perceptions of energy institutions, other entities, or individuals. Chapter 5 covers the past and potential future conservation actions, including sources of conservation financing and the impact of past conservation actions. Chapter 6 deals with the segmentation of the residential energy conservation market into prospect groups, and discusses the perceptions, attitudes, and actions of the prospect groups.

Appendix A explains the statistical significance tests for the difference between proportions and means. Appendix $B$ presents the detailed supporting information for the discussions and tables in the text. 


\subsection{F INDINGS}

Chapters 3.0 through 6.0 present detailed analyses and discussions of data and information derived from comparing the 1983 and 1985 surveys of Northwest consumer attitudes toward energy conservation. This chapter presents an overview of the findings and conclusions relating to consumer perceptions of energy conservation, perceptions of energy institutions and other entities, past and probable future conservation actions, and three market prospect groups. Some implications are also discussed.

\subsection{CONSUMER PERCEPTIONS OF ENERGY CONSERVATION}

Between 1983 and 1985, the Northwest consumers' understanding of the term "energy conservation" has progressed to the more general definition of "conserve or save energy." In 1983, when multiple definitions of the term were allowed, $74 \%$ percent of respondents gave mentions belonging in this category. In 1985, when multiple mentions were not allowed, the corresponding proportion was $86 \%$. (a) Consumers were less likely in 1985 to associate the term "energy conservation" directly with specific actions, saving money, or social responsibility. The proportion of respondents who defined energy conservation in terms of specific actions fell from $37 \%$ to $1 \%$. Those respondents who expressed energy conservation in terms of saving money decreased from $19 \%$ to zero. Energy conservation expressed in terms of social responsibility was lowered from $8 \%$ of the respondents to zero.

Within the general category of "conserve or save energy", a much larger proportion of respondents in 1985 than in 1983 defined energy conservation as "to use energy intelligently or efficiently" (40\% versus $8 \%$ ). (b) It appears that more people in the Northwest understand energy conservation to be the

\footnotetext{
(a) The magnitude of the change in perception between 1983 and 1985 should be viewed as larger than directly suggested by the difference between $74 \%$ and $86 \%$. This is because the $86 \%$ in 1983 is derived without multiple mentions while the $74 \%$ in 1986 was with multiple mentions.

(b) The essence of the note (a) above applies here.
} 
efficient use of energy, rather than simply as less use of energy or going without use of energy. This suggests that consumers' understanding of energy conservation has improved over the two year period.

Seven of the nine issues included in the 1985 survey were also included in the 1983 survey: energy conservation, inflation, unemployment, cost of energy, the environment, crime, and energy use in the home. The other two issues not included in the 1983 survey were cost of groceries and wildlife preservation. The intensity of consumers' concern about issues decreased from 1983 to 1985 as measured by the proportion of respondents who were very concerned about an issue. Of the seven issues, concern about the cost of energy decreased most. The proportion of respondents who are very concerned dropped 19 percentage points, from 70\% in 1983 to $51 \%$ in 1985. For the four issues of inflation, unemployment, energy use in the home, and energy conservation, the proportions of respondents who were very concerned about these specific issues decreased by more than 10 percentage points. Specifically, the proportion for inflation fell from 64 to 53\%; that for unemployment fell from $63 \%$ to $48 \%$; that for energy use in the home fell from $48 \%$ to $35 \%$; and that for energy conservation fell from $48 \%$ to $33 \%$.

Among the seven common issues in the two surveys, the two issues of energy conservation and energy use in the home had the lowest proportions of respondents who indicated that they were "very concerned." In 1985, these two issues had lower proportions of respondents who were very concerned than the two new issues introduced into the survey: cost of groceries and wildlife preservation. These results suggest that, although people in the Northwest are concerned about energy conservation and energy use in the home, the intensity of these concerns is not as high as those of other issues included in the survey. Therefore, it can be concluded that, if promoting energy conservation is a desirable societal objective, continued public awareness and information dissemination programs are needed to maintain public interest.

The 1985 survey included 15 statements concerning energy use and conservation, which are presented in detail in Section 3.3. The respondents were asked as to whether they agreed or disagreed with the statements. These statements 
were classified into four categories: social responsibility, self-interest/ materialism/lifestyle, limits to energy conservation, and cynicism/negative view toward energy conservation. Table 2.1 presents the results for the 10 statements that were common to both the 1983 and 1985 surveys. Three general conclusions can be made of the psychographic profiles of consumers in the Northwest from the information detailed in Section 3.3.

- Consumers generally agreed more with statements in the categories of "social responsibility" and "self-interest/materialism/lifestyle" than in the other two categories. Conversely, they disagreed more with the statements concerning the "limits to energy conservation" and "cynicism/negative views on energy conservation."

- The patterns of agreement and disagreement with individual statements appear to be parallel to between the two surveys.

- In 1985, the proportions of those agreeing are higher than those in 1983 for the statements in the categories of the social responsibility and self interest/materialism/lifestyle. One exception is the statement that "I would only make conservation investments which would enhance the value of my home." The proportion of those agreeing with the cynic view that "the amount of energy I use is really my own affair and no one else's" was also higher in 1985 than in 1983.

It appears that there was some internalization of energy conservation consciousness; i.e., consumers were becoming more energy conservation conscious. Thus, in 1985, most consumers in the Northwest (9 out of 10) disagreed with the statement that, with the current power surplus in the region, there is no need to conserve electricity. Similarly, a large majority ( 8 out of 10) disagreed with the statement that utilities should stop offering a variety of programs to encourage energy conservation.

\subsection{PERCEPTIONS OF INSTITUTIONS}

Among the seven energy institutions, the local electric utility was the most familiar to consumers in the Northwest. In 1985, only 4\% of the respondents indicated that they were not familiar with their local electric utility, 
TABLE 2.1. Psychographic Profile: Agreement and Disagreement with Statements, 1985 Versus 1983

\section{Social Responsibility \\ It's our responsibility to conserve elec- tricity for future generations \\ Conserving energy is the best way to protect the environment \\ Sel f-Interest/Material ism/Lifestyle}

Most people who conserve electricity do so to save money

I would only make conservation investments whlch would enhance the value of my home

Conserving energy is the best way to maintalning my I itestyle

\section{Limits to Energy Conservation}

I only use electrlcity when it's really

needed; there is no way I can cut down

I have already done everything I can to conserve energy

\section{Cynicism/Negative Views on Energy Conservation}

The amount of energy I use is really my own aftair and no one else's

It's silly to conserve electricity, because the electric utility just turns around and charges more for what you do use

My conservation efforts won't have much effect one way or the other on the avallabllity of electriclty

(a) A - Highest three scores $(10,9,8)$

B - Highest four scores $(10,9,8,7)$

C - Lowest three scores $(2,1,0)$

D - Lowest four scores $(3,2,1,0)$

(b) An asterisk (*) indicates that the value is significantly greater than the other values at $5 \%$ significance level.

(c) A tilde $(\sim)$ Indicates the value is significantly lower than the other values at 5\% significance level.

\begin{tabular}{|c|c|c|c|c|c|}
\hline \multicolumn{3}{|c|}{ Agreement $^{(a)}$} & \multicolumn{3}{|c|}{ Disagreement $(a)$} \\
\hline & & & \multirow{2}{*}{1985} & \multicolumn{2}{|c|}{1983} \\
\hline & $\bar{A}$ & $\bar{B}$ & & $\mathrm{C}$ & D \\
\hline \multicolumn{6}{|c|}{8} \\
\hline $85^{*(b)}$ & 71 & 77 & $10^{*}$ & $8(c)$ & 9 \\
\hline $73 *$ & 41 & 51 & $17^{*}$ & 9 & 15 \\
\hline $92^{*}$ & 75 & 83 & 6 & 4 & 5 \\
\hline $25^{*}$ & 19 & 24 & $70^{*}$ & 35 & 46 \\
\hline $62^{*}$ & 36 & 46 & $28^{*}$ & 13 & 19 \\
\hline $47 *$ & 42 & 50 & $49 *$ & 12 & 18 \\
\hline 34 * & 19 & 40 & $60^{*}$ & 19 & 27 \\
\hline
\end{tabular}

$\begin{array}{llllll}46^{*} & 26 & 32 & 49^{*} & 31 & 40 \\ 31 & 28 & 34 & 63^{*} & 34 & 41 \\ 2 น & 22 & 27^{*} & 74^{*} & 34 & 44\end{array}$


down from $12 \%$ in 1983. The energy extension service and the Northwest Power Planning Council were least familiar to the region's consumers, with about half or more of the respondents in the 1985 survey indicating they were not familiar with these two institutions. In between these extremes and in terms of increasing familiarity were state energy offices, Washington Public Power Supply System (WPPSS), the public utility commission, and BPA. Data also suggested that familiarity with energy institutions in general increased from 1983 to 1985.

With the consumers' perception of energy institution's concern for the consumer, the energy extension service received the highest rating. Eight out of ten respondents $(80 \%)$ in 1985 who were familiar with energy extension service regarded it as very concerned and concerned about the consumer. It is followed by the local electric utility $(65 \%)$, state energy office $(64 \%)$, public utility commission (60\%), and Northwest Power Planning Council (60\%). BPA was next with $48 \%$ and WPPSS was lowest with $32 \%$. (There were no corresponding data for 1983.)

Although the survey data regarding the responsibility for setting electricity prices were not directly comparable, they did suggest that consumers in the Northwest regarded the local electric utility, BPA and the public utility commission as most responsible for setting electricity prices.

In terms of overall impressions, the favorability ratings of energy institutions remained relatively constant between 1983 and 1985, except for the Northwest Power Planning Council. Among respondents who were familiar with the Northwest Power Planning Council, the proportion who viewed it very favorably and favorably rose from $47 \%$ to $65 \%$. The energy extension service and the local electric utility were the most favorably regarded energy institutions in 1985 with $82 \%$ and $74 \%$, respectively. In 1985, WPPSS was the least favorably regarded among the energy institutions, with on ly $22 \%$ of respondents familiar with its functions regarding it favorably.

Among the entities and individuals not directly related to energy matters, favorability ratings of radio and retail stores were the highest (over $80 \%$ ) in 1985. They were followed by banks and credit unions (71\%), television (71\%), 
newspapers (64\%), local elected officials (62\%), and building contractors $(57 \%)$. Realtors had the lowest rating with only one-half of the respondents (48\%) perceiving them very favorably or favorably. Among the three mass communication media, radio had the highest favorability rating; it was ahead of television by 13 points and newspapers by 20 points. There were no comparable 1983 data on the favorability of nonenergy entities and individuals.

From 1983 to 1985, the believability ratings of energy institutions, other entities and individuals, generally decreased except for the energy extension service, retail stores and the news media. The ratings for these latter entities remained relatively constant. Potential contributing factors to the lower believability ratings of institutions, entities, and individuals may include decline or relative stability of energy prices, less intense concern about energy cost, energy use in the home, and energy conservation.

The energy extension service, state energy office, the local electric utility, the news media, and retail stores appeared to be the most credible to consumers as sources of energy conservation information. Therefore, the design and implementation of strategies to reach consumers with messages about energy conservation might be more effective if coordinated with these entities.

In summary, familiarity and believability as sources of energy conservation information of energy institutions have significantly changed between 1983 and 1985. In 1985, the consumers were more familiar with energy institutions than they were in 1983. However, they were not as likely to regard the institutions, entities, and individuals as credible sources of energy conservation information in 1985 as in 1983. The favorability ratings of energy institutions remained relatively constant except for the Northwest Power Planning Council, which enjoyed an increase in the favorability rating.

\subsection{ENERGY CONSERVATION ACTIONS}

There was no significant difference between 1983 and 1985 in the proportion of respondents who picked "changing way of living" as the preferred method of conserving energy in the home $(50 \%$ to $54 \%)$. The proportion favoring spending money on improvements stayed in the $31 \%$ to $33 \%$ range. The proportion of respondents who were willing to do both fell significantly from $16 \%$ to $9 \%$. 
In 1985, most no/low cost energy conservation practices by Northwest consumers appeared to stayed at about the same level, or at a lower level of activity than in 1983. The use of shades and drapes for heating and cooling and the lowering of the thermostat setting during the heating season remained the two most frequently practiced measures; 8 or 9 out of 10 respondents stated that these measures were used on a regular basis. Among the 8 measures considered, 5 showed no significant changes in the proportions of respondents who regularly practiced them: using shades and drapes for heating and cooling (88\% to $90 \%$ ), wrapping the water heater (about $62 \%$ ), controlling lights with dimmer switches or timers (about $45 \%$ ), using water flow restrictors in showers (about $35 \%$ ), and receiving an energy audit (about 27\%). Two other measures showed decreases in the proportion who regularly practiced them: selecting energyefficient appliances when purchasing new ones (from $71 \%$ to $59 \%$ ), and putting plastic over windows (from $60 \%$ to $33 \%$ ). The only measure showing a significant increase in the proportion of respondents practicing it (from $81 \%$ to $85 \%$ ) was that of lowering the thermostat setting during the heating season.

For investment-type energy conservation measures (ECMs), 5 of the 9 measures common in the two surveys showed significant increases in the proportions of homes equipped with specific ECMs from 1983 to 1985: roof/ceiling insulation (from $77 \%$ to $92 \%$ ), outside wall insulation (64\% to $80 \%$ ), weatherproofing ( $71 \%$ to $80 \%)$, storm windows $(67 \%$ to $76 \%$ ), and clock or setback thermostat $(29 \%$ to 44\%). The proportions stayed relatively unchanged from 1983 to 1985 for two ECMs: floor, basement or crawl space insulation (54\% to 56\%), and heat pump furnace $(9 \%$ to $11 \%)$. The wood stove/furnace and storm doors were exceptions; they showed significant decreases in the proportion of homes so equipped (65\% to $41 \%$ for wood stove, and $63 \%$ to $57 \%$ for storm doors). However, the reduction in the proportion of wood stoves can be attributed to the addition of "fireplace insert" as a separate item in the 1985 survey. Many respondents in 1983 might have included fireplace insert in their responses to the question on wood stove and thus led to a higher proportion of homes equipped with wood stove/furnace for that year. There is no obvious explanation for the decline in the proportion of homes equipped with storm doors. 
Comparison of claimed installation of ECMs during 1984-85 with the intention to install ECMs from the 1983 survey revealed that the announced intention far exceeded the installations claimed in the 1985 survey in only two cases: clock or setback thermostat and heat pump furnace. In the other seven cases, claimed installations during the last two years either matched or exceeded the respondents intentions from the 1983 survey. This suggests that the responses to the question as to how likely the consumers are to install specific ECMs in the next two years can be useful for planning purposes.

During 1983-85, the average investment to install energy conservation measures by homeowners who had made some investments was about $\$ 1570$, compared to the average investment of about $\$ 1800$ for the 1981-83 period. Note that the 1983 figure was considered to be for three years. If the average amount from the 1983 survey were converted to cover a two year period, then the average investment can be said to rise from about $\$ 1200$ to $\$ 1570$ for a two-year period.

The 1985 and the 1983 results on conservation investment financing are consistent in that current income, savings, bank and utility loans, and utility payments were the primary sources of financing. Delaying or cutting back on other purchases and federal tax credits were important supplementary sources of conservation investment financing.

In 1985, the proportions of owner-occupied homes not currently equipped with specific ECMs but whose owners are likely to install ECMs in the next two or three years stayed in the range of $3 \%$ to $15 \%$, compared to the range of $6 \%$ to 13\% in the 1983 survey. Therefore, substantial potential in the near future for conservation investment is possible in the region. This potential increases with the inclusion of the following groups: those who indicated they were very likely or likely to install more of the ECMs such as weatherproofing, insulation over the ceiling and under the roof, in the walls, and under the floor, in the basement or in the crawl space.

Homeowners who had invested in ECMs during 1983-85 speculated that the value of their home had increased, on the average, by $110 \%$ of their investment. This is much less than the $160 \%$ increase from the 1983 survey. Homeowners also 
claimed that these investments lowered their monthly electric bills by $\$ 55$ in 1985, compared with an average reduction of $\$ 32$ per month in the 1983 survey.

\subsection{MARKET PROSPECT GROUPS}

In a slightly modified scheme from the 1983 survey, and using two segmentation criteria the homeowners in the region were grouped into three prospect groups. One segmentation criterion is past investment in ECMs: "1imited" past investment for 0 or 1 item, "moderate" past investment for 2 to 7 items, and "heavy" past investment for 8 or more items. The other segmentation criterion is possible future investment in the next 2 to 3 years: "minimal" future investment for zero ECM, "moderate" future investment for 1 or 2 ECMs, and "high" future investment for 3 or more ECMS. Applying these two criteria creates nine market segments. The first-tier prospect group is defined to include the three market segments of heavy-high, moderate-high, and heavy-moderate. (a) The second-tier prospect group covers the three market segments of heavy-minimal, moderate-moderate, and limited-high. The nonprospect group includes the other three segments of "limited-minimal, moderate-minimal, and limited-moderate (see Figure 2.1).

- In 1985, the size distribution of the three prospect groups remained relatively unchanged from that in 1983. First-tier prospects accounted for about 10 to $12 \%$ of the region's households. Secondtier prospects made up about one-third of the region's households $(32 \%)$. The nonprospects amounted to $29 \%$ to $31 \%$. The rest were renters $(25 \%$ to $28 \%)$.

(a) In each of the nine segments, the first of the segment designation term refers to past investment behavior while the second of the term refers likely future installation of ECMs. For example, the segment "moderatehigh" means those respondents who had installed 2 to 7 items (moderate past investment) and who also indicated that they are likely to install 3 or more ECMs in the future (high future investment). Other segments indicated in this discussion can be interpreted in a similar manner. 


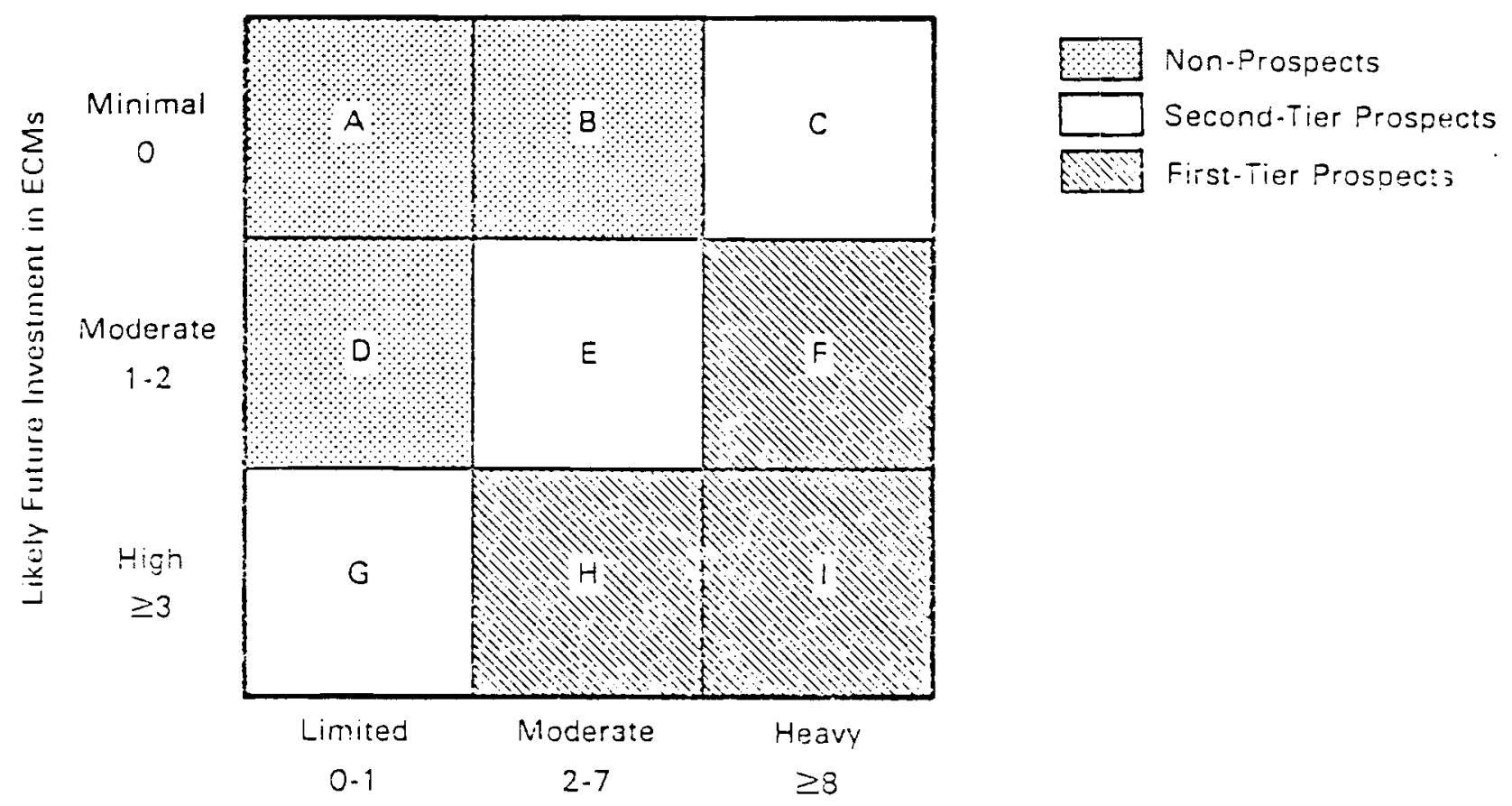

Number of Past investment in ECMs

FIGURE 2.1. Segmentation of the Residential Energy Conservation Market (excluding renters)

- In 1985, there were some changes in the psychographic profiles of prospect groups in the sense that significantly larger proportions of respondents agreed with the following 4 statements, compared with 1983 results:

Statement Reflecting Social Responsibility "Conserving energy is the best way to protect the environment." Statements Reflecting Self-Interest/Materiali sm/Lifestyle "Most people who conserve electricity do so to save money." "Conserving energy is the best way to maintain my lifestyle." Statement Reflecting Cynicism/Negative Views on Energy Conservation "The amount of energy I use is Really my own affair and no one else's."

The proportion of respondents who agreed with the statement "my conservation efforts won't have much effect one way or the other on the 
availability of electricity," decreased for first-tier and secondtier prospect groups. The proportions of respondents who agreed with the other statements remained unchanged.

- The first-tier prospect group was more likely to be very concerned about energy use in the home and energy conservation than the nonprospect group. The same was also true for issues such as inflation, crime, and the environment.

- Among those respondents who were familiar with energy institutions, the overall impressions of the Northwest Power Planning Council improved from 1983 to 1985 for all three prospect groups and that for BPA also rose for the first-tier prospect group. Otherwise, the favorability ratings of other energy institutions stayed relatively constant.

- However, the believability ratings for the local electric utility and the BPA as sources of energy conservation information fell. For other entities and individuals not directly dealing with energy matters, a decrease in the believability rating between 1983 and 1985 was observed except for retail stores and news media. Retail stores showed an increase in the believability rating for the nonprospect group. News media showed no changes for all three prospect groups.

- Compared to the first- and second-tier prospects, nonprospects were more likely to prefer changing their ways of living and less likely to prefer spending money on improvements.

- Nonprospects were less likely than first-and second-tier prospects to regularly practice no/low cost conservation actions, except for putting plastic over windows.

- By definition, the nonprospects were less likely than respondents in the two prospect groups to have their homes equipped with specific ECMs. 


\subsection{IMPLICATIONS}

With the above findings, the following implications are briefly noted.

First, with improved understanding of energy conservation and heightened level of energy conservation consciousness on the part of the consumers in the region, it would be useful to explore the ways to tap them. This can be included as part of the overall effort in building the capability to deliver conservation programs. This capability would be used to acquire conservation resources at the time when they are needed.

Second, the lower concern for energy conservation and related issues in 1985 reflected mainly the impact of changed external conditions. In addition, the intensity of concern for energy conservation and energy use was lower than that for other issues such as crime, unemployment, inflation, and the environment. These results suggest that public awareness and information programs should continue to play an important part in the effort to promote energy conservation.

Third, given the high favorability and credibility ratings of the energy extension service, the local electric utility, the news media and retail stores as sources of energy conservation information, as well as the high credibility of state energy offices, efforts to reach consumers should include them as intermediaries.

Finally, it is well known that the Northwest is currently in period of power surplus. Under the power surplus situation, the general strategy is building the capability to acquire conservation resources for application when the need arises, rather than actually acquire them at this time. This overall strategy would require different approaches for different prospect groups. For the first-tier and second-tier prospect group, the approach should be one of maintenance through promotional efforts such as public information programs, especially by providing information about the benefits of specific ECMs. Few subsidies or none at all need to be used for the duration of the power surplus. For the nonprospects, the approach should be to actively develop this group into second-tier prospect group and eventually first-tier prospect group. The goal of the approach would be to increase awareness and interest in 
specific ECMs and to persuade consumers to invest in them, at least at a minimal level. Since nonprospects are likely to be low-income households, some subsidies may be necessary, even during the period of power surplus. 


\subsection{PERCEPTIONS OF ENERGY CONSERVATION}

This chapter explains the results comparing the two surveys on consumers' perceptions and attitudes on energy conservation. First, consumer understanding of the term "energy conservation" is discussed. Concern for energy conservation and other issues is treated next. Psychographic profiles are then described in terms of agreement or disagreement with specific statements.

\subsection{UNDERSTANDING ENERGY CONSERVATION}

At the beginning of the telephone interview and after the preliminary questions pertaining to owner/renter status and electric utility bill payments, the respondents were asked the following question: "We hear a lot nowadays about 'energy conservation'. What does that phrase mean to you?" Exactly the same question was asked in both 1983 and 1985 surveys. Verbatim responses were recorded by the interviewers.

Table 3.1 provides a comparison of the two survey results by general category of the definitions given. Table 3.2 compares the results of the two surveys by the specific mentions for the general category of "conserve/save energy". The following observations can be noted: (a)

- In 1985, a large majority of respondents in the region interpreted the term "energy conservation" in a general manner. Of those interviewed, $86 \%$ responded to the above question by giving definitions that could be grouped into the general category of conserving or saving energy. This represented an increase from $74 \%$ in 1983.

- Within the category of "conserve or save energy," a much larger proportion of the respondents in 1985 defined energy conservation to mean "use energy intelligently or efficiently" than in 1983 ( $40 \%$ versus). The proportion of respondents who defined the term as

(a) However, note that the data for 1983 allows multiple mentions by a respondent while the proportions for 19851 imit the respondents to only one mention. For this reason, statistical test of significance was not conducted. 
TABLE 3.1: Meaning of the Term "Energy Conservation" by Category, 1985 Versus 1983

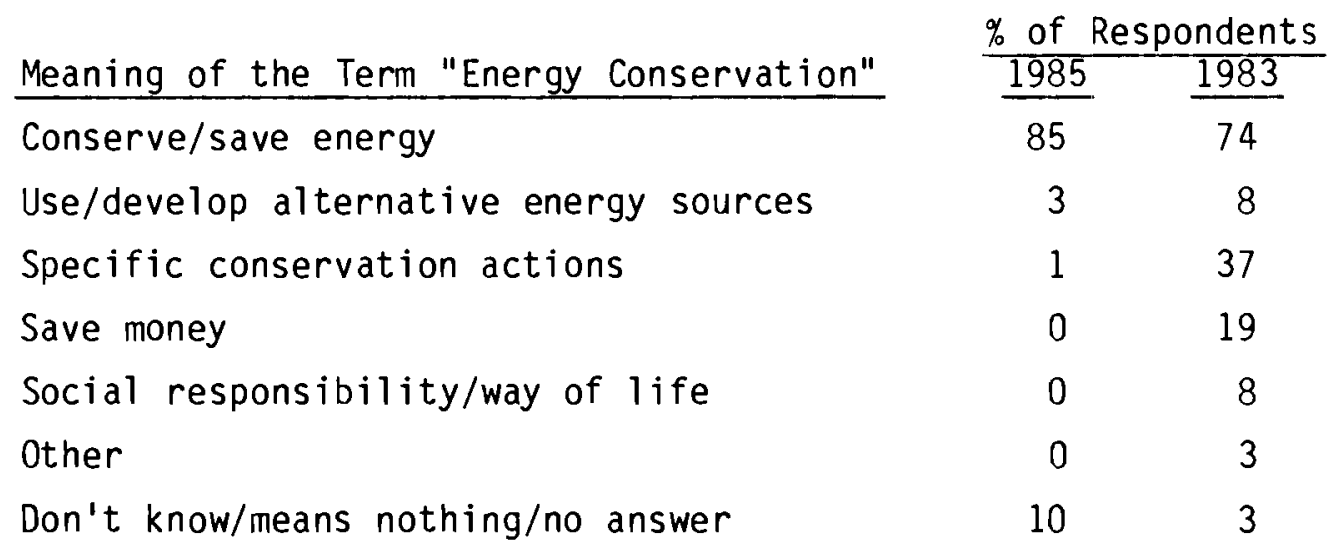

TABLE 3.2. Specific Mentions in the Category of Conserve/Save Energy, 1985 Versus 1983

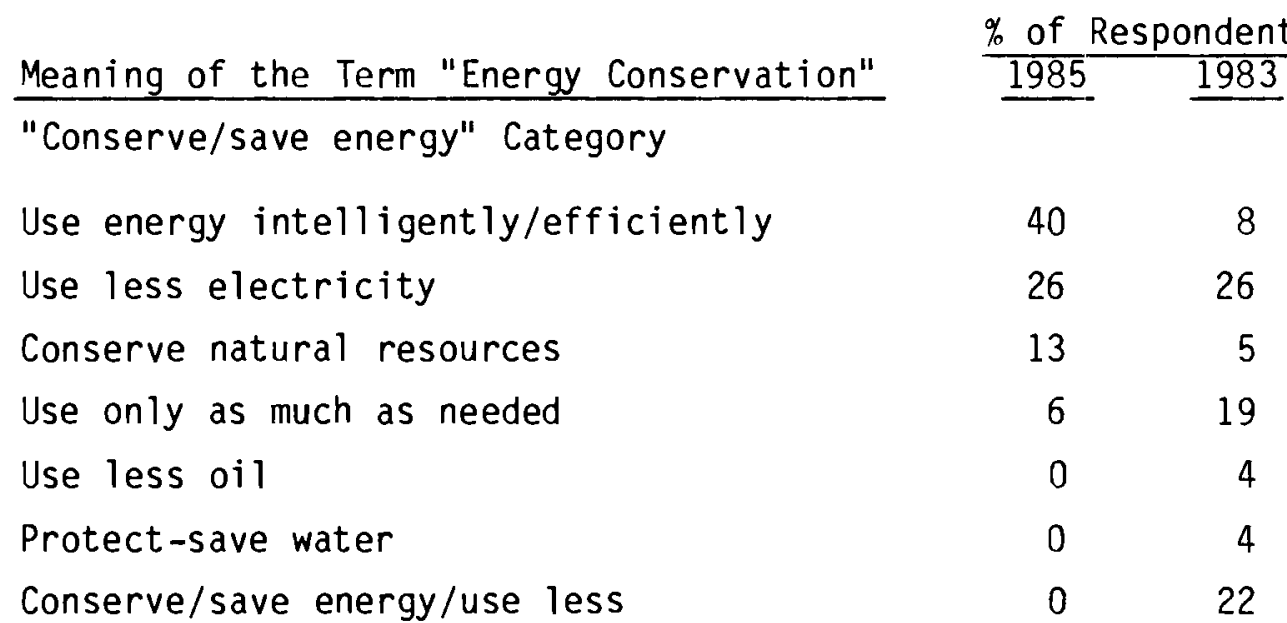

"conserve natural resources" also showed increases from 5\% in 1983 to $13 \%$ in 1985. In contrast, the proportion of those who took the term "energy conservation" to mean "use only as much as needed" declined from about $19 \%$ to $6 \%$.

- In 1983, there was a relatively large group (about 22\%) who simply gave the definition as "conserve energy," "save energy," or "use less energy." In 1985, most of such responses were further classified by 
the interviewer through additional probing and eventually led to other definitions.(a)

- The proportion of those who defined the term energy conservation as meaning "use less electricity" stayed unchanged from 1983 to 1985, at about one fourth of the respondents (26\%).

- The proportion of those who gave the definition in the categories of "specific conservation actions" or "save money" had become $1 \%$ or less in 1985 than in 1983.

- In 1983, $8 \%$ of the respondents defined energy conservation as a social responsibility or a way of 1 ife. No such response was given in the 1985 survey.

- In 1985, about $10 \%$ said it meant nothing, don't know, or refused to answer. This is compared with $3 \%$ in 1983.

Detailed data for the 1985 survey are shown in Appendix Tables B.2

and B.3. In 1985 age and sex did not appear to affect definitions given by the respondents (Appendix Table B.2). In contrast, the 1983 data showed that the older group was less likely to give definition in the category of "conserve/ save energy" and more likely to give definitions in the category of "specific actions." In 1985, income and education did impact the understanding of the term "energy conservation:" The higher income and more educated groups appeared more likely to interpret energy conservation as "using energy intelligently or efficiently", and are less likely to define it as "using less electricity" (Appendix Table B.3). One possible explanation is that the more educated and higher income respondents may be better able to perceive that "energy" covers a broader spectrum than just electricity.

To summarize, it appears that, between 1983 and 1985, the Northwest consumers' understanding of the term "energy conservation" has moved toward more mentions of definitions falling into the general category of "conserve/save

(a) This was brought to light during the debriefing meeting held in CRC office on January 10, 1985. 
energy." They were less likely to directly associate the term "energy conservation" with specific actions, saving money, or social responsibility in 1985 than they did in 1983. (a) The fact that, in 1985, 4 of 10 respondents directly associated energy conservation with the phrase "using energy intelligently or efficiently" is important. In 1983, the corresponding proportion was less than 1 of 10 . This seems to imply that more people are understanding energy conservation as efficient use of energy, rather than as simply using less energy. It can therefore be concluded that there is improved understanding of the nature of energy conservation in the residential sector of the Northwest.

\subsection{CONCERN ABOUT ENERGY CONSERVATION AND OTHER ISSUES}

Respondents were asked how concerned they were about issues such as energy conservation, inflation, unemployment, cost of energy, the environment, crime, cost of groceries, energy usage in the home, and wildlife preservation. For energy conservation, the specific question was as follows:

"Now I'm going to read you a short list of topics that some people are concerned about. Please tell me how you personally feel about each of these topics - would you say you are very concerned, somewhat concerned, not very concerned, or not at all concerned about energy conservation?"

Table 3.3 compares the results of the two surveys on these issues. It indicates that the proportions of those who were very concerned about seven issues in 1985 were significantly lower than the corresponding proportions for 1983. Two issues, cost of groceries and wildlife preservation, were added in the 1985 survey. Several observations can be noted:

- The proportion of those who indicated that they were very concerned about the cost of energy encountered the largest drop, about 19 percentage points, from $70 \%$ to $51 \%$. Relative stability of electricity price, cost of natural gas as well as falling oil prices probably caused this decrease in concern.

(a) However, see Section 3.3 for discussion on agreement with the statement that energy conservation is a social responsibility. 
TABLE 3.3. Concern About Specific Issues, 1985 Versus 1983

\begin{tabular}{l} 
Issue \\
\hline Crime \\
Inflation \\
Cost of Energy \\
Environment \\
Unemployment \\
Energy use in the home \\
Energy conservation \\
Wildlife preservation \\
Cost of groceries
\end{tabular}

\begin{tabular}{lrc}
$\%$ of Respondents & "Very Concerned" \\
\hline $\begin{array}{l}1985 \\
67 \sim(a)\end{array}$ & $\frac{1983}{74}$ & $\frac{\text { Difference }}{-7}$ \\
$53 \sim$ & 64 & -11 \\
$51 \sim$ & 70 & -19 \\
$50 \sim$ & 55 & -5 \\
$48 \sim$ & 63 & -15 \\
$35 \sim$ & 48 & -13 \\
$33 \sim$ & 48 & -15 \\
$44 \sim$ & - & - \\
$43 \sim$ & - & -
\end{tabular}

(a) A tilde ( ) indicates that the value is significantly lower than the other value at $5 \%$ significance level.

- For inflation, unemployment, energy use in the home, and energy conservation the respective proportions with "very concerned" rating also decreased by more than 10 percentage points from the 1983 levels. Relative energy price stability, lower inflation rates, and continued economic recovery probably contributed to the decrease in concern on these issues.

- Among the issues, crime remained the one issue with the highest proportion of "very concerned" responses. In 1985, two-thirds of the respondents indicated that they were very concerned, whereas threefourths indicated concern in 1983.

- In both 1985 and 1983, the two issues of energy conservation and energy use in the home had the lowest proportions of respondents who indicated they were very concerned. This suggests that, al though people in the Northwest were concerned about energy conservation and energy use in the home, the intensity of this concern was not as high as that of concerns for crime, inflation, cost of energy, the environment, unemployment, wildlife preservation, and cost of groceries. 
- For the two new issues introduced in the 1985 survey, wildlife preservation and cost of groceries, the proportions of respondents with very concerned responses were about $8 \%$ to $10 \%$ higher than those for energy conservation in the home and energy conservation.

Detailed 1985 results are summarized in Appendix Tables B.4 and B.5. Review of these two tables and the 1983 results led to the following observations:

- In 1985, the proportion of the respondents indicating they were very concerned about energy conservation was not dependent on age, sex, income and education. In contrast, in 1983, concern about energy conservation was affected by age, sex and education: female, younger (under 34), and less educated respondents were less likely than their respective counterparts to indicate that they were very concerned.

- In 1985, the proportion of people very concerned about energy use in the home was not dependent on age or sex, but was affected by income and education. The higher income and more educated groups were less likely to be very concerned about this issue. In 1983, female, younger (under 34), and more educated respondents had lower proportions of respondents who were very concerned about energy use in the home than their respective counterparts.

- In 1985, concern about the cost of energy was influenced by age, sex, income and education. The younger (under 34) group was not as likely to be concerned about the cost of energy as those in the 35 to 54 age group. Female respondents, the lower income group, and those who had a high school education or less were more likely than their respective counterparts to be very concerned about the cost of energy. The results in 1983 were the same, except income was not a factor then.

- In 1985, the older (over 55) group, female respondents, the lower income group, and the less educated appeared more likely than their respective counterparts to be very concerned about crime, inflation, unemployment. This is comparable to the situation in 1983. 
- In 1985, male, high income, and more educated respondents were less likely to be very concerned about the cost of groceries.

- In 1985, a larger proportion of the younger respondents were very concerned about the issue of wildlife preservation.

In summary, the intensity of concern on various issues surveyed decreased in 1985 compared with 1983. Among the seven issues, the largest drop in the proportion of respondents who were very concerned about a specific issue occurred in the cost of energy (19 percentage points). Probable causes for this drop were the lower oil prices and relatively stable prices of electricity and natural gas. The proportions of respondents who were very concerned about inflation, unemployment, energy use in the home, and energy conservation were also lowered by more than 10 percentage points. In both 1985 and 1983, the intensity of Northwest consumers' concern about the twin issues of energy conservation and energy use in the home was not as high as that of concern about other issues such as crime, inflation, cost of energy, the environment, and unemployment. In 1985, the intensity of concern for energy use and energy conservation was also lower than the intensity of concern for wildlife preservation and cost of groceries. This suggests that there is a need for continued public awareness and information dissemination programs to maintain and to promote public interest in energy conservation.

\subsection{ATTITUDES TOWARD ENERGY USE AND CONSERVATION}

In the 1985 survey, respondents were asked whether they agreed or disagreed with 15 statements concerning energy use and conservation. (a) The questions were posed in this manner: "I'm going to read a list of statements about how some people feel about various issues. With a response range from strongly disagree, disagree, neutral, agree, and strongly agree, please tell me how you feel about each of the following statements." Based upon the results from the 1983 survey as well as implications of the specific statements in question, these 15 statements can be grouped into four categories: social

(a) Other statements not directly related to energy use and conservation were also asked. However, they are not included in the 15 statements discussed here. 
responsibility, self-interest/materialism/lifestyle, limits to energy conservation, and cynicism/negative view on energy conservation. These fifteen statements are shown below.

Social Responsibility:

- It's our responsibility to conserve electricity for future generations.

- Conserving energy is the best way to protect the environment. Self-Interest/Materialism/Lifestyle:

- Most people who conserve electricity do so to save money.

- I would only make conservation investments which would enhance the value of my home.

- I would invest in energy conservation because it increases the comfort of my home.

- Conserving energy is the best way to maintain my lifestyle.

Limits to Energy Conservation:

- I only use electricity when it's really needed; there is no way I can cut down.

- I have already done everything I can to conserve energy.

Cynicism/Negative Views on Energy Conservation:

- The amount of energy I use is really my own affair and no one else's.

- It's silly to conserve electricity, because the electric utility just turns around and charges more for what you do use.

- My conservation efforts won't have much effect one way or the other on the availability of electricity.

- Utilities should stop offering a variety of programs to encourage energy conservation. 
- I will invest in the efficiency of my home only if there are rebates to me from the utility.

- Electricity prices in the Northwest are not high enough to necessitate conservation activities.

- With the current power surplus in the Northwest, there is no need to conserve electricity.

These four categories are used below in discussing the imagery on energy use and conservation of the consumers in the Northwest. Table 3.4 depicts that in 1985 consumers generally tended to agree more with statements in the categories of "social responsibility" and "self-interest, materialism and lifestyle" than in the other two categories. It also suggests that, in general, people disagreed more with statements in the "limits to energy conservation" and "cynicism/negative view on energy conservation" categories than with statements in the other two categories. One exception to the above generalization is the statement "I would only make conservation investments which would enhance the value of my home" in the self-interest, materialism and lifestyle category. There were more respondents who disagreed with the statement (about $70 \%)$ than those who agreed with it $(25 \%)$.

Table 3.5 presents the data for comparing the results of the two surveys. Because the 1983 survey used an 11-point scale to measure respondents' agreement with individual statements, with 10 indicating strong agreement and 0 indicating strong disagreement, two ways to group the responses in the 1983 data are used: those who agreed with the statements are assumed to have given a rating of the top three scores $(10,9,8)$ or the top four scores $(10,9$, 8, 7). (These are shown in Table 3.5 as column $A$ and column $B$, respectively.) Similarly, those who disagreed are assumed to have given a rating of the lowest three scores $(2,1$, and 0 ) or the lowest four scores $(3,2,1$, and 0 ). (These are shown in Table 3.5 column $C$ and column D.)

The patterns of agreement and disagreement with individual statements appear to be parallel between the two years. However, the proportions of those agreeing with the statements in 1985 appear to be somewhat higher than those for 1983 for the statements in the social responsibility category and those in 
TABLE 3.4. Psychographic Profiles: Agreement and Disagreement with Statements, 1985

Social Responsibility

It's our responsibility to conserve electricity for future generations

Conserving energy is the best way to protect the environment

\section{Self Interest/Material ism/Lifestyle}

Most people who conserve electricity do so to save money

I would only make conservation investments which would enhance the value of my home

I would invest in energy conservation because it increases the comfort of my. home

Conserving energy is the best way to maintaining my lifestyle

\section{Limits to Energy Conservation}

I only use electricity when it's really needed; there is no way I can cut down

I have al ready done everything I can to conserve energy

Cynicism/Negative Views on Energy Conservation

The amount of energy I use is really my own affair and no one else's

It's silly to conserve electricity, because the electric utility just turns around and charges more for what you do use

My conservation efforts won't have much effect one way or the other on the availability of electricity

Utilities should stop offering a variety of programs to encourage energy conservation

I will invest in the efficiency of iny home only if there are rebates to me from the utility

Electricity prices in the Northwest are not high enough to necessitate conservation activities

With the current power surplus in the Northwest, there is no need to conserve electricity

\begin{tabular}{lcc}
\multicolumn{2}{c}{ Percent of All Respondents } \\
\hline $\begin{array}{c}\text { Strongly } \\
\text { Agree }\end{array}$ \\
$\begin{array}{c}\text { Disagree } \\
\text { or Agree Non't } \\
\text { Neutral or Disagree Know }\end{array}$
\end{tabular}

85$$
2
$$

10

2

73

5

17

5

92

25

90

62

47

3

49

1

37

3

60

0

46

31

21

12

12

8

2

86

4

4

2

93

1 
TABLE 3.5. Psychographic Profile: Agreement and Disagreement with Statements, 1985 Versus 1983

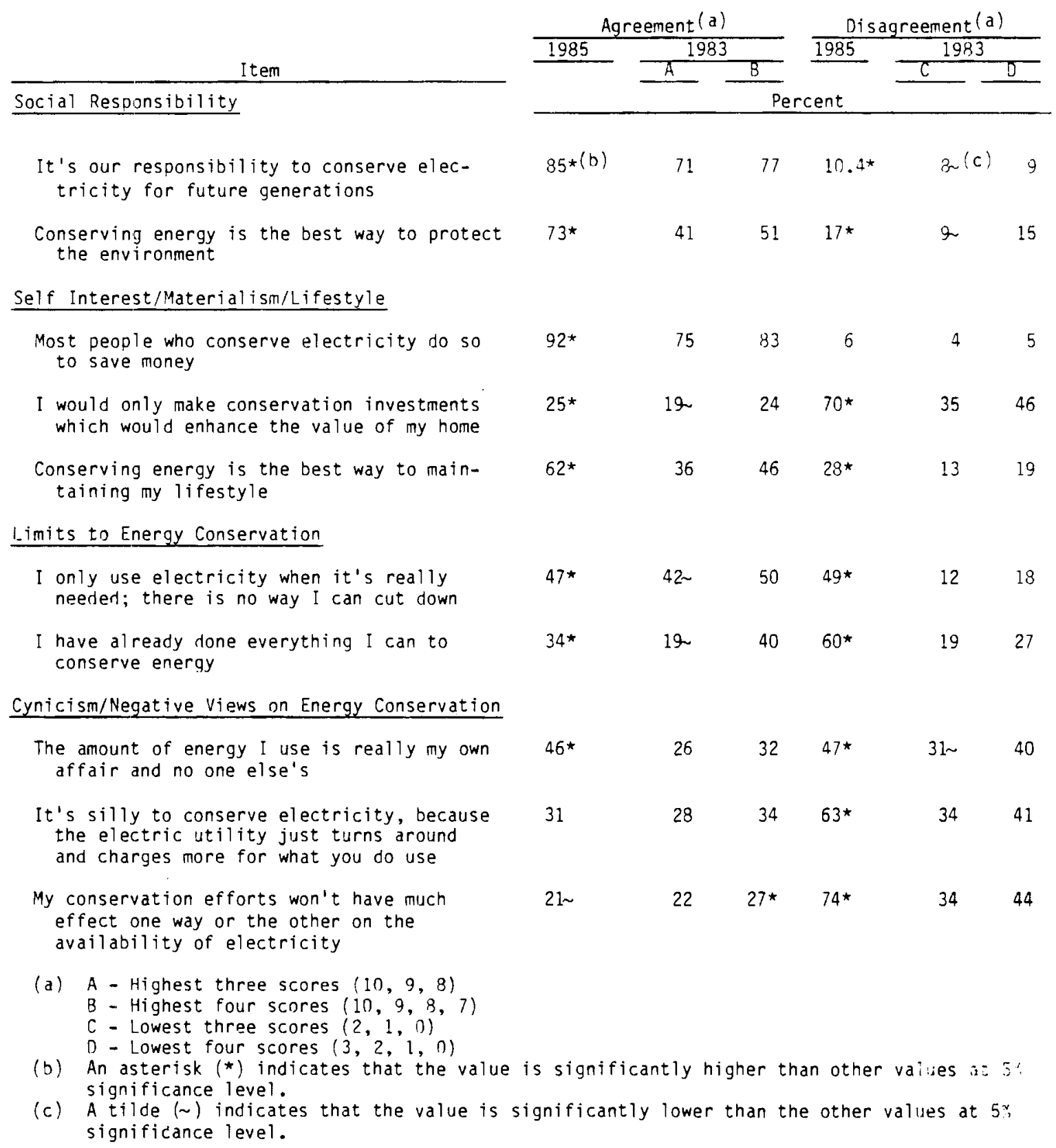

the "self-interest/materialism/lifestyle" category, except for the statement that "I would only make conservation investments which would enhance the value of my home." The proportion of those agreeing with the cynic view that "the amount of energy I use is really my own affair and no one else's" was also 
higher in 1985 than in 1983. (a) The following provides a detailed discussion by each of the four categories.

Social Responsibility

In both 1983 and 1985, a large majority of the respondents agreed with statements reflecting social responsibility. In 1985 almost 9 of 10 respondents (85\%) agreed that "it is our responsibility to conserve electricity for future generations." This can be compared with less than $77 \%$ in 1983 . The proportion agreeing with the statement that conserving energy is the best way to protect the environment was $73 \%$ in 1985 ; it was less than $51 \%$ in 1983 .

Self-Interest/Materialism/Lifestyle

In both years, agreement with statements reflecting self-interest/materialism/lifestyle was also high, except for the statement that "I would only make energy conservation investments which would enhance the value of my home." In 1985, 9 of 10 people (92\%) agreed that most people conserve electricity to save money, compared with $83 \%$ in 1983.

It is interesting to note that, when asked to explain the meaning of the term "energy conservation," less than $1 \%$ of respondents explicitly mentioned saving money. In contrast, over $90 \%$ agreed that most people conserve electricity to save money. This may be interpreted to mean that saving money is one of the objectives or expected benefits of conserving electricity, but not inherent to the meaning of energy conservation.

In 1985,6 of $10(62 \%)$ agreed that conserving energy is the best way to maintain a lifestyle. Less than half of the respondents did so in 1983 . In contrast, only a quarter of the respondents agreed, in 1985, with the statement that "I would only make energy conservation investments that would enhance the value of my home." The proportion agreeing with this statement in 1983 was about the same (column B of Table 3.5) or slightly lower (column A).

In 1985, a new statement was added to the self-interest/materialism/lifestyle category: "I would invest in energy conservation because it increases

(a) Note that some of the differences may be due to differences in the way the scales were grouped in the two surveys. 
the comfort of my home." There was overwhelming agreement with this statement (90\%) (Table 3.4). Comparing this result with that concerning the statement of investing to increase the value of the home, it appears, at first glance, paradoxical that two statements which are nearly identical in construction and which both pertain to the self-interest would produce almost opposite results. The statements refer to perceived benefits of conservation investment:

Statement

I would only make conservation investments which would enhance the value of my home.

I would invest in energy conservation

because it increases the comfort of my home.

$\%$ of A11 Respondents
Agreement

25

70

90

Closer examination reveals that the word "only" appears in one statement and not in the other. While enhancing the value of one's home is a desired benefit of installing energy conservation measures, it is not the only benefit sought. In contrast, the second statement relates a willingness to invest in order to increase the comfort level of the home. Most people can agree with such a statement.

Limits to Energy Conservation

In 1985 there were more respondents who disagreed with statements reflecting limits to energy conservation than those who agreed. Respondents were almost fairly evenly split between agreement and disagreement (46\% versus $49 \%$ Table 3.5) with the statement "I only use electricity when it's really needed; there is no way I can cut down." In 1983, agreement with the statement was about $50 \%$, but disagreement was only $18 \%$ or less.

In 1985, out of 10 respondents, about 6 disagreed and 3 agreed that "I have already done everything I can to conserve energy." In 1983, 40\% agreed and less than $27 \%$ disagreed with this statement. 
Cynicism/Negative Views on Energy Conservation

Among the seven statements in the category of cynicism/negative views on energy conservation, only one showed about the same level of agreement and disagreement in 1985. All other statements were dominated by disagreement. In 1983, there were only three statements in this category and there were more respondents who disagreed than who agreed with them.

- In 1985, $46 \%$ agreed and $49 \%$ disagreed with the statement that "the amount of energy I use is really my own affair and no one else's." In 1983 , the corresponding proportions were less than $32 \%$ in agreement and less than $40 \%$ in disagreement with it.

- Out of 10 respondents in 1985, two agreed and seven disagreed with the statement that "my conservation efforts won't have much effect one way or the other on the availability of electricity." The comparable proportions in 1983 were 27\% agreed and 43\% disagreed.

- Twice as many people disagreed $(63 \%)$ in 1985 as those who agreed with the statement $(31 \%)$ that "it's silly to conserve electricity because the electric utility just turns around and charges more for what you do use." The corresponding proportions in 1983 were $41 \%$ for disagreement and $34 \%$ for agreement.

The 1985 data also show the following results. Even with the current power surplus in the region, 9 of 10 disagreed with the view that there is no need to conserve electricity. Almost 9 of 10 disagreed with the view that electricity prices in the Northwest are not high enough to necessitate conservation activities. A large majority (more than $80 \%$ ) disagreed with the statements "utilities should stop offering a variety of programs to encourage energy conservation" and "I will invest in the efficiency of my home only if there are rebates to me from the utility" (Table 3.4). 


\subsection{PERCEPTIONS OF INSTITUTIONS}

This chapter discusses the survey results of consumers' perceptions of various energy institutions and other entities in the Pacific Northwest. Institutions dealing directly with energy matters include the respondents' local electric utility, Bonneville Power Administration, state energy offices, Public Utility Commission, energy extension service, Northwest Power Planning Council, and Washington Public Power Supply System (WPPSS). Other entities and individuals include local elected officials, banks/credit unions, realtors, building contractors, retail stores, and the mass communication media of newspaper, radio, and television. These entities and individuals were included because they may either become sources of energy conservation information to the consumers or influence their opinions and attitudes.

The respondents' familiarity with energy institutions is explained first. Perceptions of the institution's concern for the consumer and the responsibility of some of the institutions in setting electricity prices are then treated in sequence. The overall impression of the institutions and entities by the respondents is also described. Finally, the believability of these organizations and individuals as a source of energy conservation information is described. Note that the proportions shown in this chapter, except those shown in Section 4.1, are in terms of only those respondents who were familiar with the individual institutions only.

\subsection{FAMILIARITY WITH ENERGY INSTITUTIONS}

Table 4.1 presents the proportions of respondents who were not familiar with specific energy institutions. Among the seven institutions directly involved in energy matters, the energy extension service and the Northwest Power Planning Council were the least familiar to the region's population. In 1985, over half of the respondents did not know about the functions of these two institutions. For the Northwest Power Planning Council, this unfamiliarity index dropped from $60 \%$ in 1983 to $50 \%$ in 1985. In contrast, the local electric utility was the most well known. In 1985, less than $4 \%$ of the respondents 
TABLE 4.1. Proportions of Respondents Who Are Not Familiar with Energy Institutions, 1983 Versus 1985

\begin{tabular}{|c|c|c|}
\hline Institution & \multirow{2}{*}{\multicolumn{2}{|c|}{$\begin{array}{lr}\% \text { Not familiar } \\
1985 & 1983 \\
\end{array}$}} \\
\hline & & \\
\hline Local electric utility & $4 \sim$ & 12 \\
\hline Bonneville Power Administration & $26 \sim$ & 35 \\
\hline Public utility commission & 30 & -- \\
\hline WPPSS & 32 & -- \\
\hline State energy office & $43 \sim$ & 57 \\
\hline Northwest Power Planning Council & $50 \sim$ & 60 \\
\hline Energy extension service & 59 & -- \\
\hline
\end{tabular}

said they were not familiar with the local utility, showing a decline from about 12\% in 1983. In between these extremes and in terms of increasing familiarity are state energy offices, WPPSS, public utility commission, and BPA. The proportions of respondents not familiar with both BPA and state energy office have shown significant decreases, dropping from $35 \%$ to $26 \%$ for BPA and from $57 \%$ to $43 \%$ for state energy office.

In other words, familiarity with energy institutions had increased over the two-year period. This trend may be due largely to increased exposure of consumers to the activities of the institutions during the 1983-85 period.

\subsection{CONCERN FOR THE CONSUMER}

In 1985, respondents were asked questions similar to the following one for the local electric utility: "Please tell me how you feel about your electric utility in terms of their concern for the consumer. Would you say they are very concerned, concerned, not very concerned, or not at all concerned?" The respondents had the option to respond they were neutral, or to refuse to answer. There was no corresponding question in the 1983 survey.

Table 4.2 summarizes the 1985 results. Among the seven energy institutions, consumers who were familiar with the institutions regarded the energy extension service as the most concerned about the consumer in 1985. About 8 in 
TABLE 4.2. Perceptions of Energy Institutions' Concern for the Consumer, 1985

\begin{tabular}{|c|c|c|}
\hline Institution & $\begin{array}{c}\text { Households } \\
\text { Familiar With } \\
\text { Institution (1000) }\end{array}$ & $\begin{array}{l}\% \text { Very Concerned } \\
\text { or Concerned } \\
\end{array}$ \\
\hline Energy extension service & 548 & 80 \\
\hline Local electric utility & 1066 & 65 \\
\hline State energy office & 630 & 64 \\
\hline Northwest Power Planning Council & 556 & 60 \\
\hline Public utility commission & 779 & 60 \\
\hline Bonneville Power Administration & 816 & 48 \\
\hline WPPSS & 751 & 32 \\
\hline
\end{tabular}

10 respondents felt that the energy extension service was "very concerned" or "concerned" for the consumer. Local electric utility, state energy office, the public utility commission and Northwest Power Planning Council were second; about 6 in 10 respondents indicated that these institutions were concerned about the consumer. At the other extreme, Washington Public Power Supply System (WPPSS) was lowest with only about $32 \%$ of respondents believing that there was concern for the consumer. BPA was above that with $48 \%$.

\subsection{RESPONSIBILITY FOR ELECTRICITY PRICES}

Consumers were asked their perceptions of the energy institution's responsibility in setting electricity prices (Table B.10). Among those who were familiar with the energy institutions, about three-fourths of the respondents regarded the local electric utility (78\%), BPA (75\%), and Public utility commission (72\%) as "totally responsible" or "responsible". WPPSS received 69\%. Northwest Power Planning Council was lowest with $62 \%$.

The 1983 survey collected similar, but not identical, information. When asked to choose among the local utility, BPA, both, and "not sure" as the more responsible for setting the price for electricity, $41 \%$ of the respondents picked local utility; 35\% picked BPA; and 10\% picked both. Since the 1983 choices of institutions were mutually exclusive and those in 1985 were not, the proportions from the two surveys are not directly comparable. Nevertheless, 
the data suggest that consumers in the Northwest regarded the local electric utility, BPA, and the public utility commission as those most responsible for setting electricity prices.

\subsection{OVERALL IMPRESSIONS}

Respondents were asked questions similar to this one: "What is your overall impression of the BPA? Is it very unfavorable, unfavorable, favorable, or very favorable?" Table 4.3 summarizes the results for energy institutions in 1985 and compares them with the 1983 results.

In 1985, among the seven energy institutions, the energy extension service and the local utility had the highest favorability ratings in terms of overall consumer impression ( $82 \%$ and $74 \%$, respectively). Next highest ratings were in the 61 to $67 \%$ range for state energy office, Northwest Power Planning Council, and public utility commission. BPA was next with $55 \%$ and WPPSS was the lowest with only $22 \%$ of those respondents who are familiar with it regarded WPPSS very favorably or favorably.

The favorability rating of the Northwest Power Planning Council increased by 18 percentage points between 1983 and 1985, which is statistically significant.

TABLE 4.3. Overal1 Impressions of Energy Institutions, 1985 Versus 1983

\begin{tabular}{|c|c|c|c|c|}
\hline \multirow[b]{2}{*}{ Institution } & \multicolumn{2}{|c|}{$\begin{array}{c}\text { Households } \\
\text { Familiar With } \\
\text { Institution (1000) } \\
\end{array}$} & \multicolumn{2}{|c|}{$\begin{array}{l}\% \text { Very Favorable } \\
\text { or Favorable }\end{array}$} \\
\hline & 1985 & 1983 & 1985 & 1983 \\
\hline Energy extension service & 458 & -- & 82 & -- \\
\hline Local electric utility & 1066 & 2004 & 74 & 73 \\
\hline State energy office & 630 & 804 & 67 & 71 \\
\hline Northwest Power Planning Council & 556 & 578 & $65^{\star}$ & 47 \\
\hline Public utility commission & 779 & -- & 61 & -- \\
\hline Bonneville Power Administration & 816 & 980 & 55 & 49 \\
\hline WPPSS & 751 & -- & 22 & -- \\
\hline
\end{tabular}


The favorability rating in 1985 of the entities and individuals not directly related to energy are summarized in Table 4.4. Radio and retail stores had the highest favorability rating (over $80 \%$ ). They were followed by banks and credit unions, television, newspapers, local elected officials, building contractors, and realtors.

Note that, among the three mass communication media, radio had the highest favorability rating; it was ahead of the television by 13 points and of the newspaper by 20 points. The overall impression question was not asked of the nonenergy entities and individuals in the 1983 survey; hence, no comparison can be made.

\subsection{BELIEVABILITY}

A question similar to the following was asked of respondents: "Please tell me how you feel about the Northwest Power Planning Council in terms of believability as a source of information about energy conservation? Would you say it is very believable, believable, not very believable, or not at all believable?" Table 4.5 presents the results for 1985 and compares them with 1983 data. The following can be noted:

TABLE 4.4. Overall Impression of Other Entities and Individuals, 1985

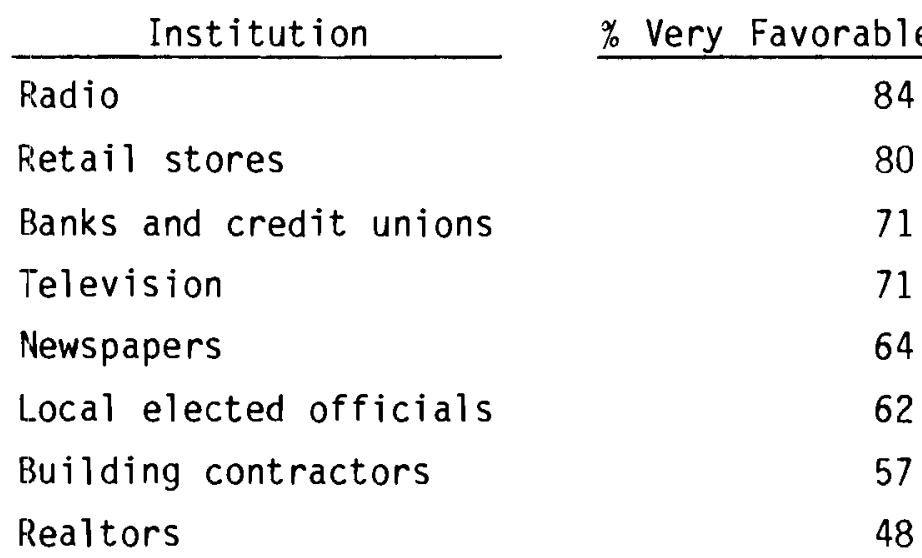


TABLE 4.5 Believability of Institutions and Entities as Sources of Information About Energy Conservation, 1985 Versus 1983

\begin{tabular}{|c|c|c|c|}
\hline Energy Institutions $(a)$ & & 1985 & 1983 \\
\hline \multirow[t]{2}{*}{ Respondents familiar with institution } & & (b) & (c) \\
\hline & $\%$ Very & Believable & and Believable \\
\hline Energy extension service & & 89 & 91 \\
\hline State energy office & & $75 \sim$ & 85 \\
\hline Local electric utility & & $73 \sim$ & 89 \\
\hline Northwest Power Planning Council & & $65 \sim$ & 77 \\
\hline Bonneville Power Administration & & 60 & 76 \\
\hline \multicolumn{4}{|l|}{ Other Entities and Individuals } \\
\hline \multirow[t]{2}{*}{ Number of Respondents } & & 686 & 2000 \\
\hline & $\%$ Very & Believable & and Believable \\
\hline Retail stores & & 70 & 66 \\
\hline News media & & $70^{(d)}$ & 74 \\
\hline Radio & & 77 & -- \\
\hline Television & & 68 & -- \\
\hline Newspapers & & 66 & -- \\
\hline Banks and credit unions & & $64 \sim$ & 76 \\
\hline Building contractors & & $55 \sim$ & 77 \\
\hline Local elected officials & & $39 \sim$ & 67 \\
\hline Realtors & & 40 & 50 \\
\hline
\end{tabular}

(a) The public utility commission and WPPSS are not included here because the believability question was not asked of respondents regarding these two institutions.

(b) For numbers of households who were familiar with the institutions in 1985, see Table 4.3.

(c) The number of households who were familiar with the institutions in 1983 (in thousands) are as follows: Energy extension service, 1,966; state energy office, 1,818; local electric utility, 2,711; Northwest Power Planning Council, 1,493; Bonneville Power Administration, 1,891.

(d) Simple average of radio, television, and newspaper. 
- In 1985, the energy extension service, state energy office, the local electric utility, the retail store, and the radio received the highest believability ranking; each received a rating of over $70 \%$ ("very believable" or "believable"). However, different trends occurred. The ratings for state energy office and the local electric utility fell while those for energy extension service, retail stores and new media(a) remained relatively constant.

- Among the five energy institutions, the energy extension service was the most credible to those who are familiar with its function, with a rating of $89 \%$ in 1985, which was about 14 percentage points higher than the state energy office, which had the next highest rating. The Northwest Power Planning Council and BPA had the lowest rating; only about 2 in 3 respondents viewed them as believable or very believable.

- Except for energy extension service, the proportions of respondents who regarded the energy institutions as either a very believable or believable source of energy conservation information had significantly declined from the 1983 levels for the other four energy institutions.

- Among other entities and individuals not directly associated with energy matters, radio and retail stores were highest in 1985 in terms of the proportion of respondents who regarded them as very believable or believable as energy information sources, $77 \%$ and $70 \%$, respectively. They were followed by the other two news media: television $(68 \%)$ and newspaper $(66 \%)$. Banks and credit unions, and building contractors were the next highest group, with $64 \%$ and $55 \%$ respectively. Local elected officials and realtors were lowest in terms of their believability rating with $39 \%$ and $40 \%$ respectively.

(a) There was only a single item of "news media" and no separate rating for the three individual media in 1983. Nevertheless, if the data for 1985 are combined to derive a group of "news media," the rating for these two years are comparable. 
- Except for retail stores and news media, the believability ratings of other entities and individuals, including banks and credit unions, building contractors, local elected officials, and realtors, were significantly lower in 1985 than in 1983.

- Among the three mass communications media, radio had the highest believability rating in 1985: $77 \%$ compared to $66 \%$ for television and $68 \%$ for newspapers. In a survey conducted for the Northwest Power Planning Council in February, 1982, the believability rating for the three media were virtually the same: $78 \%$ for television and newspaper, and $76 \%$ for radio (Fang 1985 , p. 4.4 ).

In summary, except for retail stores, energy extension service and news media, there was a general decline in 1985 in the believability ratings of the energy institutions and other entities. Potential contributing factors to the lower believability ratings may include decline or relative stability of energy prices, less intense concern about cost of energy, energy use in the home, and energy conservation. Among the entities and institutions, the energy extension service, state energy office, the local electric utility, the news media, and retail stores appeared to be the most credible as sources of energy conservation information. Hence, efforts to reach the consumers with messages about energy conservation might be more effective if coordinated with these five entities.

\subsection{DISCUSSION}

The specific tracking hypothesis for the consumers' perceptions of institutions, noted in Chapter 1.0, states that "image profiles of institutions with respect to familiarity, overall impressions, and believability as a source of energy information remain unchanged since 1983." Given the analyses presented above, the results of the tests conducted for this hypothesis can be summarized as follows:

- Familiarity with energy institutions increased between 1983 and 1985. The proportion of respondents who were unfamiliar with the local electric utility fell from $12 \%$ to $4 \%$; that for BPA dropped from $35 \%$ to $26 \%$; that for state energy office decreased from $57 \%$ to $43 \%$; 
and that for the Northwest Power Planning Council changed from $60 \%$ to $50 \%$. All these changes are statistically significant (Table 4.1).

- In terms of overall impressions, favorability ratings of energy institutions remained relatively constant, except for Northwest Power Planning Council. The proportion of respondents who were very favorably and favorably impressed with the Northwest Power Planning Council rose from $47 \%$ to $65 \%$ (Table 4.3 ).

- From 1983 to 1985, there was a general decline in the believability rating of energy institutions, and other entities and individuals, except for the energy extension service, retail stores and the news media. The ratings for these latter entities remained relatively constant (Table 4.5).

It can be concluded from the above results that significant changes occurred between 1983 and 1985 in the image profiles of energy institutions with respect to familiarity and believability as sources of energy conservation information. In 1985, consumers in the Northwest were more familiar with energy institutions than they were in 1983. However, they were less likely to regard the institutions, entities and individuals as very believable or believable as sources of energy conservation information. The favorability ratings of energy institutions remained relatively unchanged except for the Northwest Power Planning Council, which enjoyed an increase in the favorability rating. 


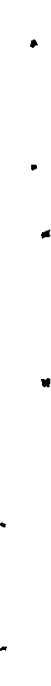




\subsection{ENERGY CONSERVATION ACTIONS}

This chapter explains the conservation actions taken by the respondents. Preferred methods for conserving energy are discussed first. Past conservation actions are then covered, including topics such as no/low cost conservation measures, investment-type energy conservation measures (ECMs), average amount of investment, and sources of financing. Possible future installations of ECMs are also explained. Finally, the impacts of past investments on the value of the home and on the average monthly utility bills are noted.

\subsection{PREFERRED METHODS FOR CONSERVING ENERGY}

To determine preferred methods of conserving energy at home, the respondents were asked the following question: "There are many ways to reduce your energy use at home. Some of these ways involve spending money on such things as solar water heating, insulation and heat pumps. Other ways require changes in the way you live, such as lowering the thermostat, using less hot water, wearing a sweater indoors in the winter, and so forth. Given a choice between the two--spending money on improvements or changing the way you live--which would you say you would rather do to save energy at home?" Table 5.1 summarizes the 1985 results and compares them with the 1983 data.

TABLE 5.1. Preferred Method of Conserving Energy, 1985 Versus 1983

\begin{tabular}{|c|c|c|}
\hline Item & 1985 & 1983 \\
\hline \multirow{2}{*}{$\begin{array}{l}\text { Number of Households } \\
(1,000)\end{array}$} & 3022 & 3117 \\
\hline & \multicolumn{2}{|c|}{ Percent } \\
\hline Changing way of living & 54 & 50 \\
\hline Spending on improvement & 33 & 31 \\
\hline Both & $\operatorname{gr}(a)$ & 16 \\
\hline Neither & 1 & 2 \\
\hline Don't know/not sure & 3 & $1 \sim$ \\
\hline
\end{tabular}

(a) A tilde $(\sim)$ indicates that the value is significantly lower than the other value at $5 \%$ significance level. 
In 1985 over half of the respondents (54\%) said that they preferred changing their way of living, which is roughly the same as in 1983 (50\%). About one in three respondents (33\%) preferred spending money on improvements in 1985 , compared with $31 \%$ in 1983. In 1985, about one-tenth (9\%) of the respondents said that they prefer to do "both"--change their way of living and also spend on improvements. This represented a significant decline from the $16 \%$ in 1983.

\subsection{NO/LOW COST CONSERVATION PRACTICES}

Past conservation actions include minor changes in ways of living, ECMs requiring little or no investment, and ECMs that require larger investments. Examples of no/low cost conservation practices are: reduce thermostat settings, dress warmer during the heating season, and put plastic over windows. Examples of investment-type ECMs are add more insulation over the ceiling, under the floor, or in the wall; weatherproof the house; and install storm doors, storm windows, or wood stoves. This section discusses the results on no/low cost conservation practices while the next section treats the investment-type ECMs.

Except for wording changes in one instance, the same eight no/low-cost energy conservation items were asked of the respondents in the 1985 survey as in the 1983 survey. The question asked in the 1985 survey is as follows: "I will read you a few specific energy conservation measures. Please tell me which of these conservation practices you have done or have regularly followed during the last two years (1983 until now). Control lights with dimmer switches or timers?" Table 5.2 presents the 1985 results and compares them with 1983 data. The results are as follows:

- In 1985 as in 1983, using shades and drapes for heating and cooling was the most frequently practiced conservation action. Approximately 9 out of 10 respondents indicated that they regularly followed the practice.

- The second most frequently followed practice in both 1985 and 1983 was lowering thermostat settings during the heating season. The 
TABLE 5.2. Low Cost Energy Conservation Measures Regularly Used, 1985 Versus 1983

\begin{tabular}{|c|c|c|}
\hline \multirow{3}{*}{$\frac{\text { Item }}{\text { Number of Households }(1,000)}$} & 1985 & $\underline{1983}$ \\
\hline & 3022 & 3117 \\
\hline & \multicolumn{2}{|c|}{ Percent } \\
\hline Use shades for heating and cooling & 90 & 88 \\
\hline $\begin{array}{l}\text { Lower thermostat settings in the } \\
\text { heating season }\end{array}$ & $85 *$ & 81 \\
\hline Wrap water heater & 63 & 62 \\
\hline $\begin{array}{l}\text { Select energy-efficient appliance } \\
\text { when purchasing a new one }\end{array}$ & $59 \sim$ & 71 \\
\hline $\begin{array}{l}\text { Control lights with dimmer switches } \\
\text { or timers }\end{array}$ & 44 & 45 \\
\hline Use water flow restrictors in showers & 36 & 35 \\
\hline Put plastic over windows & $31 \sim$ & 60 \\
\hline Receive energy audit & 27 & 27 \\
\hline
\end{tabular}

proportion of those who have done this or regularly followed the practice rose significantly by 4 percentage points from $81 \%$ in 1983 to $85 \%$ in 1985 .

- Wrapping the water heater was third on the 1ist. In either year, almost two-thirds (63\%) of the respondents indicated that their water heaters have been wrapped. Since the water heater needs to be wrapped only once, this suggests that there were relatively few cases of wrapping water heaters during 1984-85.

- The proportions of those who regularly practiced the actions for two no/low cost conservation practices decreased significantly from 1983 to 1985: selecting energy efficient appliances when purchasing new ones (from $71 \%$ to $59 \%$ ), and putting plastic over windows (from $60 \%$ to $31 \%$ ). It should be noted that a change in wording may have accounted for part of the decrease in the proportion of those who regularly put plastic over their windows. In the 1983 survey, the term "put up storm windows" was used. In answering the question phrased in this 
manner, respondents could have included the investment-type measure. (a) In other words, the 1983 figure might have been overstated.

- The proportions of households that controlled lights with dimmer switches or timers, that used water flow restrictors in showers, and that had received an energy analysis or audit had stayed relatively unchanged between 1983 and 1985: approximately 44\% for controlling lights with dimmer switches, $36 \%$ for using water flow restrictors and approximately $27 \%$ for receiving an energy audit.

Thus, comparison of 1985 data with 1983 data produces mixed results. In 1985, most no/low cost energy conservation practices by Northwest consumers appeared to be either at the same or at slightly lower levels of activity than in 1983. Use of shades and drapes for heating and cooling and lowering thermostat settings during the heating season remained the two most frequently practiced measures. The proportions of respondents who regularly used shades for heating and cooling, had wrapped their water heaters, controlled lights with dimmer switches or timers, had used water flow restrictors in their showers, or received an energy audit remained relatively unchanged between the two years. In contrast, the proportions of those respondents who regularly selected energy-efficient appliances when purchasing a new one, or put plastic over their windows had declined from 1983 to 1985. Finally, lowering thermostat settings during the heating season was the only practice that showed an increasing proportion of households that regularly practiced it.

\subsection{ENERGY CONSERVATION INVESTMENTS}

Whereas 11 investment-type energy conservation measures were included in the 1983 survey, 12 measures were included in the 1985 survey. Common to both surveys are the following 9 ECMs:

(a) In the 1983 survey, the term "put up storm windows" appeared under the question on no/low cost conservation measure and the term "storm windows/thermal window panes" was used in the question on investment-type ECMs. 
- Weatherproofing

- Storm windows (thermal window panes)

- Roof or attic insulation

- Floor, basement or crawl space insulation

- Wall insulation

- Storm or insulated doors

- Heat purnp (furnace)

- Wood stove or furnace

- Clock or setback thermostat.

The 1985 survey included 3 new items: fireplace inserts, solar panels for water heating, and heat pump water heaters. Fireplace insert was added to the 1985 survey to distinguish from the free standing wood stove. The 1983 survey included two items which were not repeated: solar panels for space heating, and sun space or passive solar.

Table 5.3 presents, according to time of installation, the 1985 results of past investments in ECMs in owner-occupied homes. Table 5.4 presents a comparison of the proportion of homes equipped with specific ECMs between 1983 and 1985. Some of the important results are noted below:

- According the respondents in the 1985 survey, nine of ten homes (92\%) had roof or attic insulation, up from $77 \%$ in 1983. In 1985, eight of ten owner-occupied homes had weatherproofing, wall insulation, or storm/thermal pane windows. All three measures showed significant increases in the proportion of homes currently equipped with the ECM in question. The proportion of homes with wall insulation rose from $64 \%$ in 1983 to $80 \%$ in 1985. Similarly, the proportion for weatherproofing increased from $71 \%$ to $80 \%$ and that for storm/thermal pane windows rose from $67 \%$ to $76 \%$.

- The proportion of owner-occupied homes with insulation in the floor, basement or crawl space had stayed relatively the same between 1983 and 1985: $54 \%$ to $55 \%$ 
TABLE 5.3. Proportions of Owner-Occupied Homes (a) with Specific Energy Conservation Measures According to Time of Installation, 1985 (Percent)

\begin{tabular}{|c|c|c|c|c|}
\hline Item & $\begin{array}{l}\text { Currently } \\
\text { Equipped } \\
\end{array}$ & $\begin{array}{l}\text { Installed } \\
\text { Within } \\
\text { the Last } \\
2 \text { Years } \\
\end{array}$ & 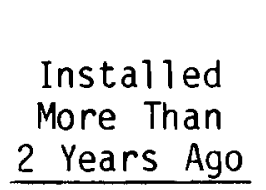 & $\begin{array}{c}\text { There } \\
\text { When } \\
\text { Moved in } \\
\end{array}$ \\
\hline Roof or attic insulation & $92 \%$ & $13 \%$ & $28 \%$ & $51 \%$ \\
\hline Wall insulation & 80 & 6 & 19 & 55 \\
\hline Weatherproof ing & 80 & 31 & 27 & 21 \\
\hline Storm windows & 76 & 15 & 27 & 35 \\
\hline Storm or insulated doors & 57 & 10 & 21 & 26 \\
\hline $\begin{array}{l}\text { Floor, basement or crawl space } \\
\text { insulation }\end{array}$ & 55 & 10 & 19 & 26 \\
\hline Clock or setback thermostat & 43 & 6 & 14 & 22 \\
\hline Wood stove/furnace & 39 & 8 & 23 & 9 \\
\hline Fireplace insert & 20 & 3 & 13 & 4 \\
\hline Heat pump (furnace) & 9 & 1 & 4 & 4 \\
\hline Heat pump water heater & 3 & 0 & 1 & 2 \\
\hline Solar panels for water heating & 2 & 1 & 1 & 0 \\
\hline
\end{tabular}

(a) Total number of owner-occupied homes was about 2,150 in thousands.

- In 1983, less than 3 in 10 owner-occupied homes (29\%) was equipped with a clock or setback thermostat. In 1985, the corresponding ratio rose to over 4 in 10 , or $43 \%$.

- The cases of storm doors and wood stoves proved to be major exceptions: the proportions declined. In 1983, 65\% of the respondents occupying their own homes indicated that the house was equipped with a wood stove/furnace. In 1985, this proportion was significantly lower, at $39 \%$. This lower percentage can be partially attributed to the inclusion of fireplace insert as a separate item in the list of investment-type ECMs in the 1985 survey. In the 1983 survey, fireplace insert was not listed separately and some 
TABLE 5.4. Proportions of Owner-Occupied Homes Currently Equipped with Specific Energy Conservation Measures, 1985 Versus 1983

\begin{tabular}{|c|c|c|}
\hline \multirow{3}{*}{$\begin{array}{l}\text { Number of owner-occupied } \\
\text { homes }(1000)\end{array}$} & 1985 & 1983 \\
\hline & 2150 & 2356 \\
\hline & \multicolumn{2}{|c|}{ Percent } \\
\hline Roof or attic insulation & $92^{\star}$ & 77 \\
\hline Wall insulation & $80^{\star}$ & 64 \\
\hline Weatherproofing & $80^{*}$ & 71 \\
\hline Storm windows & $76^{*}$ & 67 \\
\hline Storm or insulated doors & $57 \sim$ & $63 \sim$ \\
\hline $\begin{array}{l}\text { Floor basement or crawl space } \\
\text { insulation }\end{array}$ & 55 & 54 \\
\hline Clock or setback thermostat & $43^{*}$ & 29 \\
\hline Wood stove/furnace & 39 & 65 \\
\hline Fireplace insert & 20 & -- \\
\hline Heat pump furnace & 9 & 11 \\
\hline
\end{tabular}

respondents might have included fireplace insert in their responses to the "wood stove/furnace" question. (a) In contrast, there is no obvious explanation for the decline of the proportions of homes equipped with storm doors from 63\% in 1983 to $57 \%$ in 1985.

- The proportion of homes equipped with heat pump furnaces remained relatively constant at $9 \%$ to $11 \%$ between 1983 and 1985 .

- In 1985, the proportion of owner-occupied homes equipped with heat pump water heaters was about $3 \%$, and that with solar panels for water heating was about $2 \%$.

In summary, among the nine ECMs with comparable data from both the 1985 and 1983 surveys, five show statistically significant increases in the proportions of homes equipped with the specific ECMs: roof/ceiling insulation, weatherproofing, storm windows, wall insulation, and clock or setback

(a) Note, however, that even if the 1985 figure on fireplace insert (20\%) were added to that of wood stove/furnace, the combined proportion would be $60 \%$ in 1985. This is still significantly lower than the $65 \%$ for 1983. 
thermostat. Three ECMs had shown no significant changes either way: storm or insulated doors, floor-basement-and crawl space insulation, and heat pump furnaces. Wood stove/furnace was a major exception because it showed a significant decrease in the proportion of homes so equipped. A large part of the reduction in the proportion can be accounted for by the separate listing of fireplace insert in the 1985 survey.

Although there are no comparable data from the 1983 survey, the following results from the 1985 survey are also important.

- More than half of the owner-occupied homes currently equipped with roof/ceiling insulation, wall insulation or clock thermostat control were pre-existing; i.e., so equipped when the respondents moved into the home. Similarly, close to half of those homes occupied by the owner and equipped with storm doors, storm windows, and insulated crawl space were pre-existing (Table 5.3). In contrast, the proportions of homes in which the ECMs were installed since the respondents moved into the homes are shown in Table 5.5 .

TABLE 5.5. Proportions of Owner-Occupied Hornes for Which Specific ECMS are Installed Since Respondents Moved In, 1985

\section{ECM}

Weatherproofing

Roof or attic insulation

Storm windows

Storm doors

Wood stove

Floor, basement or crawl space insulation

Wall insulation

Clock or setback thermostat

Fireplace insert

Heat pump (furnace)

Solar panels for water heating

Heat pump water heater
$\%$ Installed Since Moved In

58

41

41

31

30

29

25

20

16

5

2

1 
- About one in three homeowners claimed that they had weatherproofed their home during 1983-85. About one in ten homeowners said that they had added roof insulation, storm windows, or added insulation to the basement or crawl space (Table 5.3).

In addition, the 1983 survey asked homeowners who had not installed specific ECMs if they intended to install them in the next 2 or 3 years. The 1985 survey collected data on specific ECMs installed during the 1983-85 period. It is thus possible to compare the intentions with the installations in an aggregate sense. Table 5.6 provides some interesting insights:

TABLE 5.6. Proportions of Homeowners Installing Specific Energy Conservation Measures--Comparison Between Intention and $\mathrm{Cl}$ aimed Installation

\begin{tabular}{|c|c|c|}
\hline Item & $\begin{array}{c}\text { Installed } \\
\text { During } \\
1984-85 \\
\end{array}$ & $\begin{array}{l}\text { Indicated } \\
\text { "Very Likely" } \\
\text { and "Likely" } \\
\text { in the } 1983 \\
\text { Survey } \\
\end{array}$ \\
\hline \multirow[t]{2}{*}{ Number of Homeowners (1000) } & 2150 & 2356 \\
\hline & \multicolumn{2}{|c|}{ Percent } \\
\hline Weatherproofing & $31^{\star}$ & 10 \\
\hline Storm windows & 15 & 11 \\
\hline Roof/attic insulation & $13^{\star}$ & 6 \\
\hline Storm or insulated doors & 10 & 13 \\
\hline Wood stove/furnace & 8 & 8 \\
\hline Wall insulation & 6 & 6 \\
\hline $\begin{array}{l}\text { Floor, basement or crawl space } \\
\text { insulation }\end{array}$ & 10 & 9 \\
\hline Clock or setback thermostat & $6 \sim$ & 11 \\
\hline Fireplace insert & 3 & -- \\
\hline Heat pump (furnace) & $1 \sim$ & 12 \\
\hline
\end{tabular}

- Compared to the intention expressed in $1983(10 \%)$, the proportion of owner-occupied homes that were weatherproofed during 1984-85 was significantly higher (31\%). The proportion of homes that added insulation to under the roof or above the ceiling during the last two 
years was also higher (13\% versus $6 \%)$. The proportion for storm windows rose from $11 \%$ to $15 \%$. Note, however, that two of these three ECMs are among the four items that even if homes are currently equipped with them, more can be added (see discussion in Section 5.6, relating to Table 5.9 ).

- The proportions of actual installation of clock or setback thermostat or heat pump furnaces were much lower than the proportions of those who indicated intentions to do so. The proportion of intended installation was $11 \%$, while actual installation was only $6 \%$ for clock thermostat setback. Similarly, for heat pump furnace, intended installation proportion was about $12 \%$ while actually installation claimed was less than $1 \%$.

- There was agreement between the expressed intentions and the installations claimed for 1983-85 period for wood stoves (about 8\%), wall insulation $(6 \%)$, storm doors ( $11 \%$ to $13 \%)$, and floor, basement or crawl space insulation ( $9 \%$ to $10 \%$ ). However, the case of wood stoves needs to be noted. As explained above, it is possible the 1983 data for wood stove included fireplace inserts. For this reason, the data for fireplace insert and wood stove for 1985 may be combined to become $11 \%$, which is higher than the $8 \%$ for 1983 .

The above comparison between the intentions to install specific ECMs revealed in the 1983 survey and the actual installations of ECMs claimed in the 1985 survey reveals that in only two cases, clock or setback thermostat and heat pump furnace, the intention expressed in the 1983 survey far exceeded actual installation claimed in the 1985 survey. In the other seven cases claimed installations during the last two years either exceeded or matched the announced intentions in the 1983 survey. These results suggest that the responses to the question as to how likely the consumers are to install specific ECM in the next two years, with appropriate allowances for specific circumstances, can be useful for planning purposes. 


\subsection{AVERAGE CONSERVATION INVESTMENT}

During 1983-85, the average investment by homeowners in installing energy conservation measures was about $\$ 1570$. This appeared to be lower than $\$ 1800$ average investment for the 1981-83 period (Table 5.7). However, the 1985 results covered only two years (1983-85), while the 1983 result covered three

TABLE 5.7. Average Conservation Investment, 1985 Versus 1983

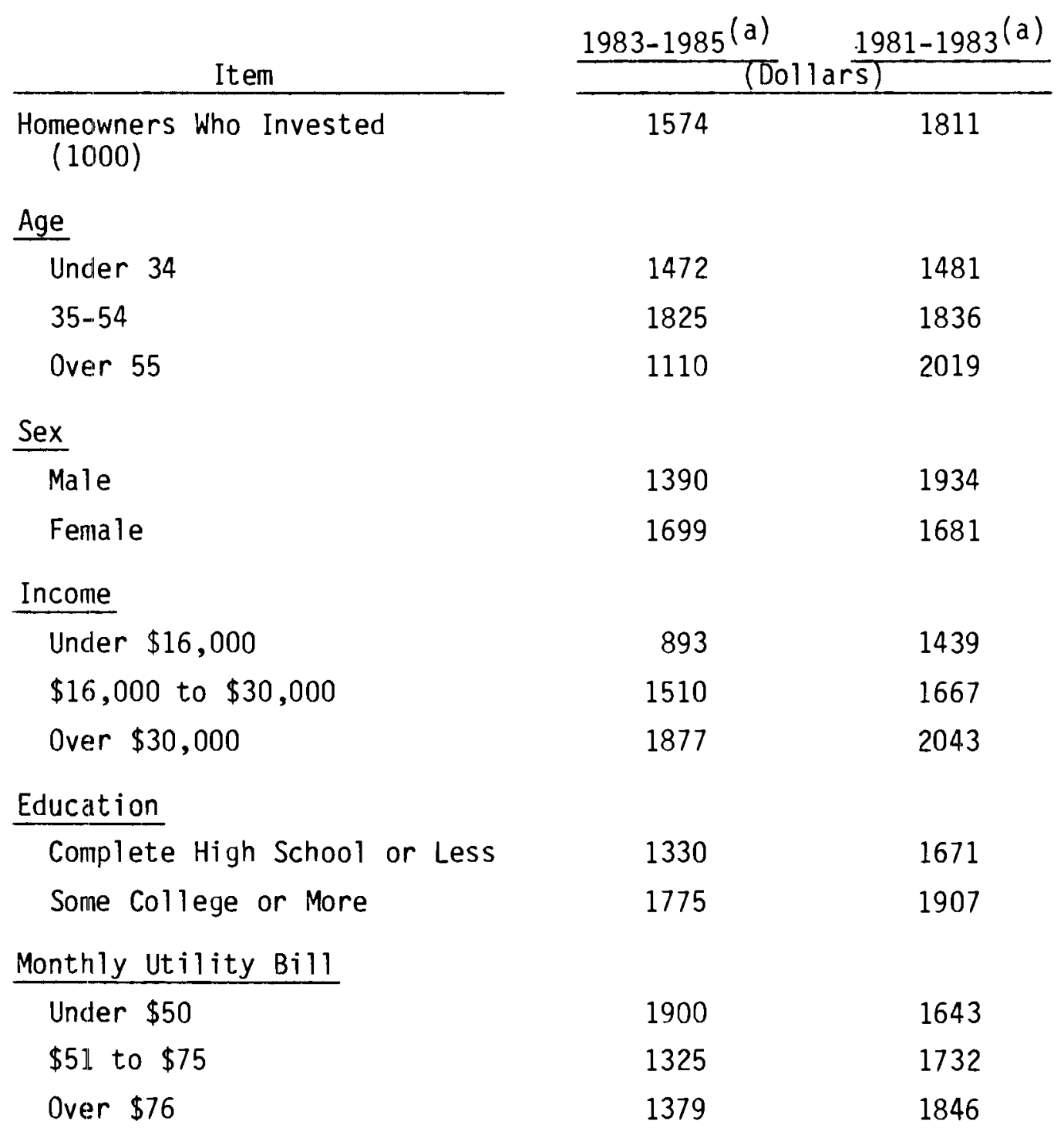

(a) Note that data from the 1985 survey covers the two year period of 1983-85, while data from the 1983 survey covers the three years of 1981-83. 
years (1981-83). Converting to the same basis of two years, the 1983 results are close to $\$ 1200$, which is somewhat lower than the 1985 average. Thus, the adjusted overall average investment rose from $\$ 1200$ to $\$ 1570$ for two years, between 1983 and 1985.

In the 1985 survey, the average investment for those homeowners in the middle age group (35 through 54) was higher than that for the younger group (under 34 years of age), about $\$ 1800$ versus $\$ 1100$. In contrast, the 1983 results showed that the older group (over 55) had the highest average investment.

The average investment for the 1983-85 period was lowest for the lower income group. This is consistent with the results from the 1981-83 period, which showed that the lower income group has the lowest average investment.

\subsection{SOURCES OF FINANCING}

In the 1985 survey, the respondents were asked the question: "Of everything spent on energy conservation for your home, where did the biggest proportion of money come from?" In the 1983 survey, the question was asked: "How did you pay for the energy conservation improvements you made in your home in the past 2 or 3 years--did you (Read List; Multiple Record) use money from current income (Yes; No)? Delay other purchases (Yes; No)? .." Thus, the 1983 survey permitted and recorded substantial number of multiple mentions. Although the 1985 survey also allowed multiple responses, the number was small; and most have been included in a separate category of "combination of two or more sources." With these considerations in mind, Table 5.8 presents the 1985 results and compares them with the 1983 results.

Money from current income was the most important source of conservation investment financing in both surveys. In 1985, six of ten homeowners who had invested in energy conservation measures over the 1983-85 period (63\%) indicated that money from current income was the most important source in financing their investment. In 1983, 3 of 4 homeowners (75\%) said that they had used current income in financing their investment. Although the proportion in 1985 appeared to be lower than that for 1983, part of the difference might be due to the possibility that, for some respondents in 1983, money from current income 
TABLE 5.8. Financing Sources for Energy Conservation Investment, 1985 Versus 1983

\begin{tabular}{lccc}
\multicolumn{1}{c}{ Item } & & $\frac{1985}{\text { Percent }}$ of Homeowners \\
Current income & 63 & $1983^{(a)}$ \\
Savings & 19 & 38 \\
Delay or cut back other purchases & 2 & 47 \\
Bank loans and credits & 8 & 13 \\
Utility loans & 2 & 8 \\
Payments by utility & 3 & 9 \\
Paid by others & 1 & -- \\
Federal tax credits & 1 & 23 \\
Combined sources & 2 & -- \\
Other & 0 & 0
\end{tabular}

(a) 1983 data include multiple mentions.

was a supplementary, instead of the primary, source of financing. This possibility arose because the construction of the 1983 question on financing sources allowed multiple mentions of potential sources. Thus, even if a homeowner used primarily savings, utility payments, or other sources to finance the installation of ECMs and supplemented with money from current income, he could still mention current income as a financing source. In contrast, under the question for the 1985 survey, he would not have been able to mention current income as the source of biggest proportion of money for financing the investment.

Money from savings was the second most often mentioned source of financing. In 1985, almost 1 of 5 respondents (19\%) said that savings were the largest sources of financing. In 1983, almost 2 of $5(38 \%)$ indicated savings as one of the financing sources. (a)

(a) In 1983, the combined category of "delay or cut back other purchases" was larger with $47 \%$. However, when separated, each of them was lower than the savings category at $21 \%$ or $27 \%$. See more discussion on this category below. 
For $10 \%$ of the respondents, combined bank loans and utility loans, were the third most important financing source in 1983-85. Allowing for multiple mentions, loans from banks, credit unions, and the local utility combined were mentioned by $21 \%$ of respondents who were homeowners in the 1983 survey.

In 1985, the investment was largely paid by the utility or others for about $4 \%$ of the responding homeowners. In 1983, utility payments was mentioned by about $9 \%$ of homeowner respondents.

The other financing sources mentioned included cutting back or delaying other purchases, federal tax credits, combination of two or more sources, and others. In 1985, these sources combined to account for less than $5 \%$ of the number of homeowners. However, in 1983 when multiple responses were allowed, the combination of these sources was mentioned by $70 \%$ of the relevant respondents in 1983. Nearly half (47\%) of the respondents mentioned that they paid for the investment by delaying or cutting back on other purchases. When the question was 1 imited to one mention of the "biggest portion of money" in 1985, delaying and cutting back on other purchases were mentioned by only about 2 percent of the respondents. Similarly, in 1983 about 1 of 4 respondents said that they paid for conservation investment through federal tax credits. In 1985, the proportion was less than $1 \%$. These results suggest that delaying or cutting back on other purchases and federal tax credits are important supplementary sources of financing conservation investment, but not the primary sources. Another factor could have contributed to the smaller role of federal tax credit in financing the installation of ECMs in 1985. This factor could be the limitation on federal residential weatherization credits; it was available to only those houses constructed before Apri1, 1977. Perhaps by the end of 1983, most of the homes eligible for federal income tax credits had been substantially weatherized.

In short, the 1985 results on conservation investment financing discussed above are consistent with the 1983 results in the sense that current income, savings, bank and utility loans, and utility payments were the most frequently mentioned or primary financing sources. The above results also suggest that delaying or cutting back on other purchases and federal tax credits are important supplementary or secondary source of financing conservation investment. 


\subsection{LIKELY FUTURE CONSERVATION INVESTMENT}

For each of the 12 ECMs included in the 1985 survey, respondents whose homes were not currently equipped with a specific ECM were asked a question similar to this one: "How likely is it that you will spend money to install weatherproofing (caulking-weatherstripping) within the next 2 or 3 years? Would you say it is very likely, somewhat likely, not very likely, or not at all likely?" Respondents whose homes were equipped with four specific ECMs (including weatherproofing, insulation in the floor/basement/crawl space, insulation in outside walls, and insulation in the roof or attic), were also asked a question similar to this one: "How likely is it that you will spend money to install more outside wall insulation in your current residence within the next 2 or 3 years? Would you say it is very likely, somewhat likely, not very likely, or not at all likely?" Table 5.9 presents the results for 1985 and compares them with 1983 data. Some of the more salient aspects can be noted below:

- For weatherproofing, insulation in the floor/basement/crawl space, insulation in outside walls, and insulation under the roof or in the attic, the 1985 proportions of homes likely to install or add more of these (including those currently equipped with the specific ECM in question) more than doubled the proportions of homes currently not equipped and likely to install in the next 2 or 3 years. Weatherproofing was the most dramatic, with its proportion increasing by 30 percentage points from about $7 \%$ to $41 \%$. Roof or attic insulation would increase from $3 \%$ to $21 \%$. Floor/basement or crawl space insulation would increase from about $9 \%$ to $16 \%$. The proportion of homes likely to install wall insulation would go up to $11 \%$ from $4 \%$ (a)

- Excluding homes currently equipped with the ECMs in question, the proportion of homes likely to install in the next 2 or 3 years ranged from $3 \%$ for installing ceiling insulation to $15 \%$ for storm doors. This is comparable to the range of $6 \%$ to $13 \%$ in the 1983 survey.

(a) In the 1983 survey, data were collected only from homes currently not equipped with the specific ECM. 
TABLE 5.9. Likelihood of Installing Specific ECMs During the Next Two to Three Years, 1985 Versus 1983

Item

Number of homeowners (1000)

Weatherproofing $(A)$

Roof or attic insulation (A)

Floor/basement/crawlspace insulation (A)

(B)

Storm or insulated doors

Insulated outside walls (A)

Wood stove/furnace

storm/thermal pane windows

Fireplace insert

Clock or setback thermostat

Heat pump (furnace)

$$
\frac{1985}{2150} \quad \frac{1983}{2356}
$$

Percent ${ }^{(a)}$ Very Likely or Somewhat Likely
$41 \sim \overline{10}$

$21 \quad--$

16

99

$15 \quad 13$

$11 \quad-$

56

98

9 11

$9 \quad--$

$7 \sim \quad 11$

$7 \sim \quad 12$

(a) Computed as proportions of all homeowners.

(A) Includes all owner-occupied homes whether or not they are currently equipped with specific ECM but are "very likely" or "somewhat likely to install more insulation."

(B) Including only owner-occupied homes currently not equipped with the specific ECM in question.

Thus, the proportion of households likely to install in the next two or three years appeared to stay in the same order of magnitude in 1985 as in 1983: floor/basement/crawl space insulation (about 9\%), outside wall insulation (about $5-6 \%$ ), storm doors (13\% to 15\%), and wood stoves ( $8 \%$ to $9 \%$ ).

- The proportions of owner-occupied homes not currently equipped with specific ECMs but likely to install such ECMs in the next 2 or 3 years appeared to have declined for weatherproofing (from $10 \%$ to $7 \%$ ), roof attic insulation (from 6\% to 3\%) storm windows (from 11\% in 1983 
to $9 \%$ in 1985), clock or setback thermostat (from $11 \%$ to $7 \%$ ), and heat purnp furnaces (from $12 \%$ to $7 \%$ ).

- If fireplace insert were combined with wood stove, the proportion of homes indicating they were likely to install this measure would show an increase from $8 \%$ to about $18 \%$.

In summary, the proportions of owner-occupied homes not currently equipped with specific ECMs but likely to install the relevant ECMs in the next two or three years (in the total number of owner-occupied homes) stayed in the range of $3 \%$ to $15 \%$ in 1985 . These proportions are more or less consistent with those in the range of $6 \%$ to $13 \%$ in the 1983 survey. Thus, it appears that there is still substantial potential in the near future for conservation investment in the Northwest. This potential is even higher with the inclusion of those homes currently equipped with some of the ECMs and whose owners also indicated very likely or likely to install more of the measures. Four measures are in this category: weatherproofing, insulation over the ceiling and under the roof, in the walls, and under the floor, in the basement or in the crawl space.

\subsection{IMPACTS OF CONSERVATION INVESTMENT}

Two specific impacts of energy conservation investments perceived by the respondents were measured in both surveys: increased value of the home and difference in the average monthly heating bill. This section briefly explains the results of the comparison of the two surveys.

In 1985, about $45 \%$ of the homeowners answered "yes" to the question of whether they felt that their investment in energy conservation measures made a difference in the value of their homes. However, only about $25 \%$ of the homeowners were able or willing to speculate on the amount of increase in that value. The average increase in the value of homes claimed by those who were willing to speculate was $\$ 1797$ in 1985 , compared with $\$ 2908$ in 1983 . Since the average investment made during $1983-85$ was $\$ 1574$, the ratio of perceived increases in home values to conservation investment made is 1.1 , compared with the 1.6 ratio computed from 1983 survey results (Table 5.10). 
TABLE 5.10. Average Increases in Home Values Due to Energy Conservation Investment, 1985 Versus 1983

\begin{tabular}{llrrr} 
Item & & 1985 & & 1983 \\
\cline { 1 - 1 } & & $\$ 1787$ & & $\$ 2908$ \\
Average Conservation Investment & & $\$ 1574$ & & $\$ 1811$ \\
Ratio of Perceived Average Increases in & & 1.14 & & 1.61 \\
$\quad$ Home Value Due to Average Conservation & & \\
Investment & & &
\end{tabular}

This result suggests that, on the average, respondents who had invested in energy conservation measures in the 1985 sample speculated that the value of their home would increase by about $110 \%$ of the value of the investment made. In comparison, homeowners in 1983 speculated that the value of their homes would increase on the average by $160 \%$ of the investment made. One possible explanation of this phenomenon is that there may be a heightened realism in 1985, compared to 1983. Northwest consumers may have become more realistic in 1985 in estimating how investments in ECMs can be translated into the resale value of their homes. An alternative explanation is that homeowners were more pessimistic in 1985 than in 1983 regarding the rate of increase in home values.

With respect to the impact on utility bills, respondents claimed that, in 1985, the energy efficiency improvements made in their homes led to reductions of $\$ 59$ in their average monthly utility bills. This is about $80 \%$ higher than that claimed by the respondents in the 1983 sample (\$32). Two factors might have contributed to the greater amount of savings claimed in 1985 than in 1983. First, the rates charged for electricity in 1985 could have been higher in 1985 than in 1983. Second, the 1983 survey asked for estimates by respondents in terms of total annual saving whereas the 1985 survey asked for average monthly saving. Since the average monthly figure is smaller than the annual figure, there could be a tendency to give a value that tended to bias upward. 


\subsection{MARKET SEGMENTATION}

This chapter categorizes consumers in the Northwest, excluding renters, into three prospect groups based on a slightly modified scheme from that used in the 1983 survey analysis. The attitudes, perceptions, and conservation actions are compared among the three prospect groups and between 1983 and 1985. The definitions of the market segments and prospect groups are discussed first. This is followed by explanations of the demographic and energy use characteristics of the two samples by prospect group. The attitudes, perceptions, past and likely future conservation actions, and sources of financing are then explored in turn, with emphasis on identifying trends and changes between 1983 and 1985. The final section discusses the results of testing on the tracking hypothesis concerning prospect groups noted in Chapter 1.0 .

\subsection{DEFINING MARKET SEGMENTS AND PROSPECT GROUPS}

For the purpose of this report, consumer segments for energy conservation action in the Northwest can be defined by past behaviors and expressed intentions. Past investment categories include "limited" (1 or zero ECM installed), "moderate" (2 to 7 ECMs installed), and "heavy" ( 8 or more ECMs installed). Future intention categories are "minimal" (no ECM to be installed), "moderate" ( 1 or 2 ECMs to be installed), and "high" ( 3 or more ECMs to be installed). Nine market segments are created by combining the two segmentation criteria. They are depicted in Figure 6.1 and 1 isted below:

\begin{tabular}{|c|c|c|}
\hline Segment & Past Investment & Future Investment \\
\hline$A$ & limited & minimal \\
\hline B & moderate & minimal \\
\hline C & heavy & minimal \\
\hline $\mathrm{D}$ & limited & moderate \\
\hline$E$ & moderate & moderate \\
\hline$F$ & heavy & moderate \\
\hline G & limited & high \\
\hline$H$ & moderate & high \\
\hline $\mathrm{I}$ & heavy & high \\
\hline
\end{tabular}




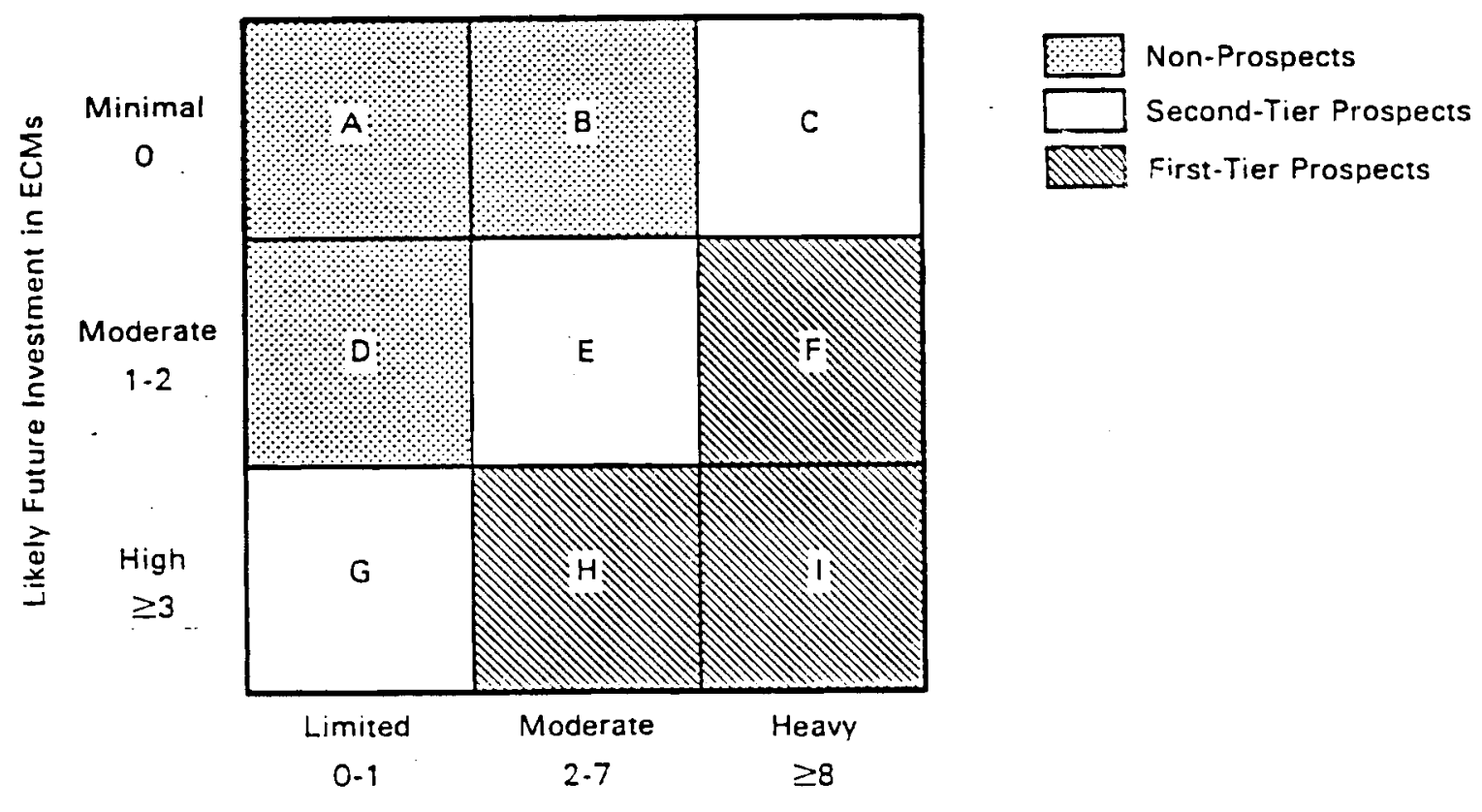

Number of Past Investment in ECMs

FIGURE 6.1. Segmentation of the Residential Energy Conservation Market (excluding renters)

Three prospect groups are then determined by combining market segments according to the likelihood of actual installation of ECMs. The First-tier prospects are defined to include segments F, H and I. This group represents those consumers who are most likely to make investments in conservation: they have installed at least 2 items in the past and indicated they are likely to install at least one item in the next two or three years. However, those who are in the moderate past investment and the moderate likely investment category, i.e., those in the $E$ segment, are excluded.

The Second-tier prospects are defined to include segments C, E, and G. Segment $C$ are those who have invested heavily but indicated that they are not likely install any ECM in the near term. However, due to their past experience in energy conservation investment, it is assumed that through public information programs and incentive programs it is possible to induce these consumers to install more ECMs. Segment $G$ are those consumers who have had only limited 
investment in the past but are in the "high" likely investment category. However, their expressed intentions were somewhat discounted by virtue of their relative lack of past investment record.

The Nonprospects include segments A, B, and D. Their past investment record is either "moderate" or "limited" and their expressed investment likelihood is "minimal" or "moderate."(a) These consumers are unlikely to install energy conservation measures in the near term on their own or under normal circumstances. To reach them, it may be necessary to design and develop programs with heavy subsidies or particular focus, such as low-income weatherization.

Since renters are not included in the nine consumer segments used in defining the three prospect groups, they become a fourth prospect group in order to represent the entire residential sector for existing homes. Table 6.1 suggests that the relative proportions of the three prospects groups remain relatively unchanged between 1983 and 1985.(b) About 1 in 10 respondents are First-tier prospects. The other 9 of 10 respondents are about equally distributed between Second-tier prospect group (about 32\%), Nonprospect group (about $30 \%$ ), and renters (about $28 \%$ ).

TABLE 6.1. Distribution of Prospect Groups, 1985 Versus 1983

(Percent)

\begin{tabular}{|c|c|c|c|c|}
\hline \multirow[b]{2}{*}{ Group } & \multicolumn{2}{|c|}{$\begin{array}{l}\text { Including } \\
\text { Renters }\end{array}$} & \multicolumn{2}{|c|}{$\begin{array}{l}\text { Excluding } \\
\text { Renters }\end{array}$} \\
\hline & 1985 & 1983 & 1985 & 1983 \\
\hline First-tier prospect & 10 & 12 & 14 & 16 \\
\hline Second-tier prospect & 32 & 32 & 45 & 43 \\
\hline Nonprospect & 29 & 31 & 41 & 41 \\
\hline Renter & 29 & 25 & -- & - \\
\hline All Groups & 100 & 100 & 100 & 100 \\
\hline
\end{tabular}

(a) However, households in the moderate-moderate segment are excluded; they are in the Second-tier prospect group.

(b) See Table B.32 and Table B.33 in Appendix B, respectively, for 1985 and 1983 data on market segments and the derivation of prospect groups. 
Note that the proportions for 1983 in Table 6.1 are different from those cited in Chapter 1.0. This is due to the differences in the definitions of prospect groups explained above and those used in the 1983 survey report (RMH Research, Inc. 1984a). Several factors contributed to necessitate the modification of the definitions used in this tracking analysis. First, ambiguities in the earlier definitions and available documentation on the data tape did not allow exact replication of the analysis results of the 1983 survey. Second, it is unreasonable to include those in the First-tier prospect groups (Segment $C$ in the scheme of Figure 6.1) who have installed many conservation measures and who indicated that they would not install any more ECMs. To do so would completely disregard the respondents negative intentions toward future investment. It is, however, reasonable to argue that, due to their past investment experiences, it is likely that respondents in Segment $C$ can be persuaded through public information and incentive programs to eventually adopt some of the measures with which their homes are not currently equipped. This is the reason that Segment $C$ is included in the Second-tier prospect group in the current scheme. Third, a reverse logic is used to include Segment $G$ in the Second-tier prospect group. The expressed intention to install many ECMs is somewhat discounted by the lack of prior investment behavior.

\subsection{DEMOGRAPHICS AND ENERGY USE CHARACTERISTICS}

Appendix Tables B.34 and B.35 present the results of testing the differences between proportions of the demographic and energy use characteristics of the prospect groups. The data contained in Table B.34 show the differences between the two surveys. Table B.35 provides the test results on the differences among the prospect groups separately for 1985 and 1983.

In general, age, education, and income appear to be important determinants for the segmentation scheme among the prospect groups developed in Section 6.1. Younger and higher income respondents, and those with at least some college education appeared to be more likely to be in the First- and Secondtier prospect groups. 0lder and lower income respondents and those with no more than a high school education were more likely than their counterparts to be in the Nonprospect group. Occupation was also important. The Nonprospect 
group had smaller proportions of respondents in the white collar occupations such as professionals, managers, sales, and clerical. Type of residence, and the primary fuel used in heating the home were not important factors in determining the prospect status of respondents. Changes between 1983 and 1985 occurred in the proportions of respondents by gender (the Second-tier prospects and Nonprospects), by age (Nonprospects), by education (First-tier prospects), by income (Nonprospects), and by type of residence (the Second-tier prospects).

The detailed differences by demographics and energy use are highlighted below:

- Gender. Reflecting the significantly larger proportions of female respondents in the 1985 sample, the proportions of females in Secondtier and Nonprospect groups were significantly higher than the corresponding proportions in 1983. For the First-tier prospect group, the female proportion is also higher in 1985 than in 1983, but this difference is statistically insignificant. Nonprospect group was more likely than the Second-tier prospect group to have a higher proportion of female respondents in 1985.

- Age. Age appears to be an important factor in determining the prospect group with which a respondent is identified. The First-and Second-tier prospect groups are more likely to have significantly larger proportions of mid-age (between 35 and 54) and younger (under 34) respondents than the Nonprospect group. Conversely, the Nonprospect group is composed of a larger proportion of older (over 55) respondents. In 1985, for example, the proportions for the First-tier prospects were $43 \%, 46 \%$, and $9 \%$ respectively for the younger, mid age, and older groups. In contrast, the corresponding proportions for the Nonprospect group were $14 \%, 35 \%$, and $51 \%$ respectively.

The only changes in the relative proportions by age group occurred in the Nonprospect group. The proportion of younger (34 and under) respondents in this group was significantly lower in 1985 than in 
1983 (14\% versus 25\%). The proportion of older respondents (over 55 years old) was significantly higher in 1985 than in $1983(51 \%$ versus $41 \%$ ).

- Education. In 1983, the proportion of respondents in the First-tier prospect group who had had at least some college education was significantly higher than a similar proportion for the Second-tier prospect group which, in turn, was significantly higher than the same proportion for the Nonprospect group. In 1985, such a relationship is true only for the Second-tier prospect group. For the First-tier prospects, there was a significant decrease in the proportion of respondents who had at least some college education in 1985 from the level in 1983. No significant changes were observed for the other two prospect groups.

- Occupation. In general, the Nonprospect group had lower proportions of respondents who were in the professional, managerial, and clerical/sales occupational groups than the other two prospect groups. The only significant change between the two surveys occurred in the Second-tier prospect group: the proportion of respondents in this group who were in managerial positions rose from $7 \%$ in 1983 to $11 \%$ in 1985.

- Income. Income is also an important factor which affected the composition of the prospect groups. The Nonprospect group had larger proportions of lower income (under $\$ 16,000$ ) respondents and simaller proportions of high-income (over $\$ 30,000$ ) respondents than the Firstand Second-tier prospects. For example, in 1985, 32\% of the Nonprospect respondents had incomes less than $\$ 16,000$, compared to $12 \%$ and $14 \%$, respectively, for the First- and Second-tier respondents. On the other hand, the Nonprospect group's proportion of respondents with incomes over $\$ 30,000$ was $30 \%$ in 1985 , compared to $43 \%$ and $41 \%$ respectively for the First- and Second-tier prospect groups. The only significant change between 1983 and 1985 occurred in the Nonprospect group. The proportion of Nonprospect respondents in the 
middle income group fell significantly from $39 \%$ in 1983 to $27 \%$ in 1985. The offsetting changes occurred in terms of increases in the proportions of lower income groups.

- Type of Residence. In 1983, the proportion of Nonprospect respondents living in single family detached homes was $83 \%$, which was significantly less than the $90 \%$ for both the First-and Second-tier prospects. Correspondingly, there was a significantly larger proportion (13\%) of Nonprospect households living in mobile homes and other similar structures than the proportions in the other two prospect groups (about 5\%). In the 1985 sample, this difference among prospect groups was no longer observed. Otherwise, the only significant change between the two years was that the proportion of Secondtier prospect respondents living in mobile homes rose from $6 \%$ in 1983 to about $11 \%$ in 1985 .

- Primary Heating Fuel. There were no significant differences in the fuel shares among the three prospect groups in either 1985 or 1983. There were no significant changes in the individual fuel shares from 1983 to 1985.

\subsection{ATTITUDES TOWARDS ENERGY CONSERVATION OF PROSPECT GROUPS}

This section discusses the attitudes of the prospect groups towards energy conservation and use. In particular, the concerns about various issues are explained first. The psychographic profiles in terms of agreement with various statements concerning energy use and conservation are also explored. 6.3.1 Concern About Various Issues

Table 6.2 compares, by prospect group, the proportions of respondents who were very concerned about the specific issues in 1985 with the relative proportions in the 1983 survey. The following are significant highlights resulting from this comparison: 
TABLE 6.2. Concern About Various Issues by Prospect Groups, 1985 Versus 1983

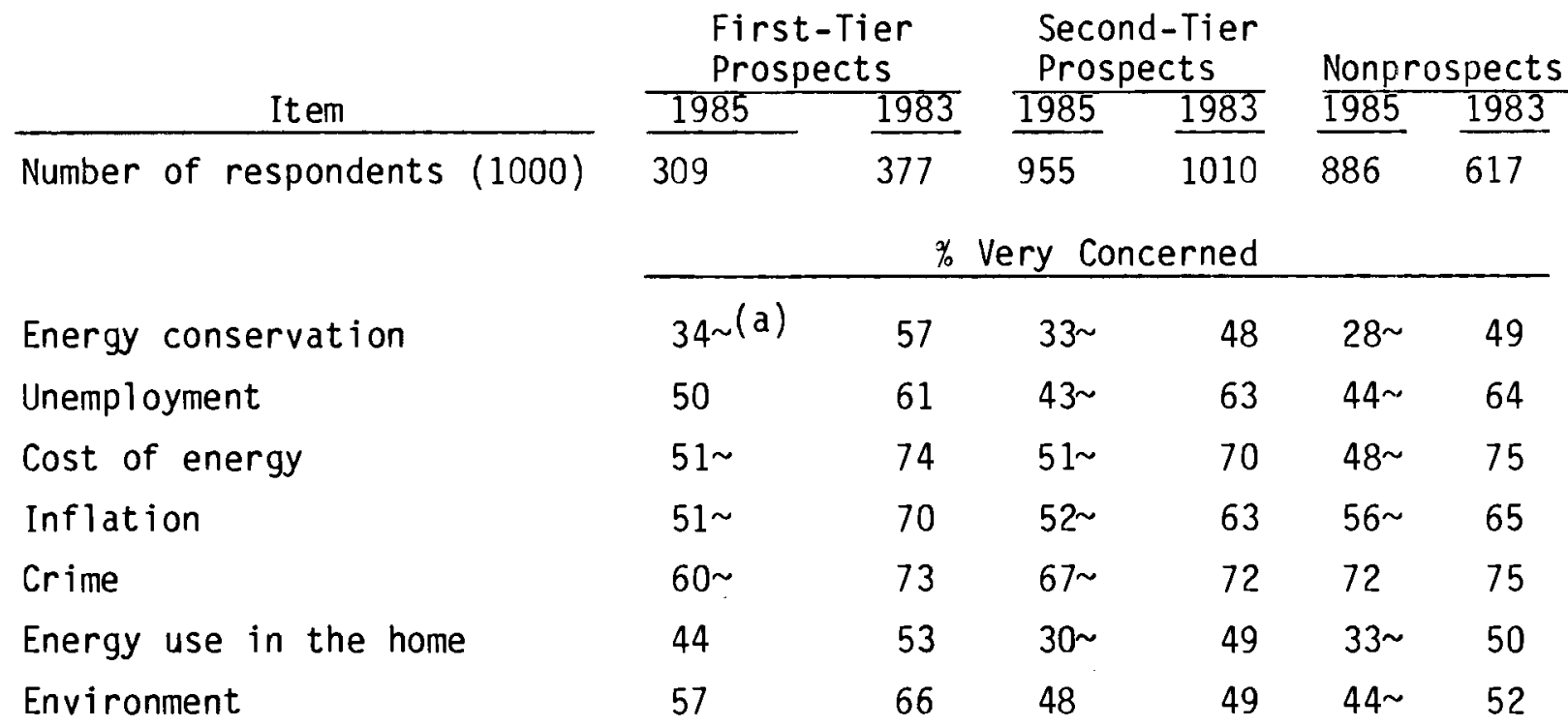

(a) A tilde ( ) indicates that the value is significantly lower than the other values at $5 \%$ significance level.

- Reflecting the overall drop in concern explained in Section 3.2, the proportions of those who were very concerned about energy conservation, cost of energy, and inflation were significantly lower for all three prospect groups in 1985 when compared with the 1983 results.

- For First-tier prospects, the proportion of those who were very concerned about crime was also significantly lower in 1985 than in 1983.

- For Second-tier prospects, the proportions of those who were very concerned about unemployment, crime, and energy use in the home were also lower in 1985 than in 1983.

- For the Nonprospects, the proportions of those who were concerned with unemployment, energy use in the home, and environment were also lower in 1985 than 1983.

Table B.36 in Appendix B provides separate comparison test results for 1985 and 1983. These tests reveal the following: 
- In 1983, the proportion of respondents who were very concerned about energy conservation was significantly higher in the First-tier prospect group than in the Nonprospect group. In 1985, there was no significant difference.

- In both 1983 and 1985, there were no significant differences among prospect groups in terms of the proportion of respondents who indicated that they were very concerned about unemployment, the cost of energy, and inflation.

- The First-tier prospects were more likely than other groups to be very concerned about energy use in the home (1985), and the environment (both 1983 and 1985). They are also less likely to be concerned about crime than the Nonprospect group (1985).

To summarize, several aspects can be noted. First, although changes in external conditions have contributed to a general decrease in concern about energy conservation, cost of energy, and energy use in the home from 1983 to 1985, the First-tier prospect group had higher proportions than the Nonprospect group of those who were very concerned about energy conservation, and energy use in the home. However, the proportion of those who were very concerned about the cost of energy was not significantly different among the three prospect groups. Second, the First-tier group was less concerned about crime than the Nonprospect group.

\subsubsection{Psychographic Profiles}

Table 6.3 compares the prospect groups' psychographical images between 1983 and 1985 in terms of the proportions of respondents who agreed with 10 attitudinal statements common to both surveys. The table depicts that, consistent with the overall results discussed in Section 3.3, proportions of respondents agreeing with the statements increased significantly for all three prospect groups between 1983 and 1985 for the following 5 statements:

"It's our responsibility to conserve electricity for future generations."

"Conserving energy is the best way to protect the environment." 
TABLE 6.3. Psychographical Images, 1985 Versus $1983^{(a)}$

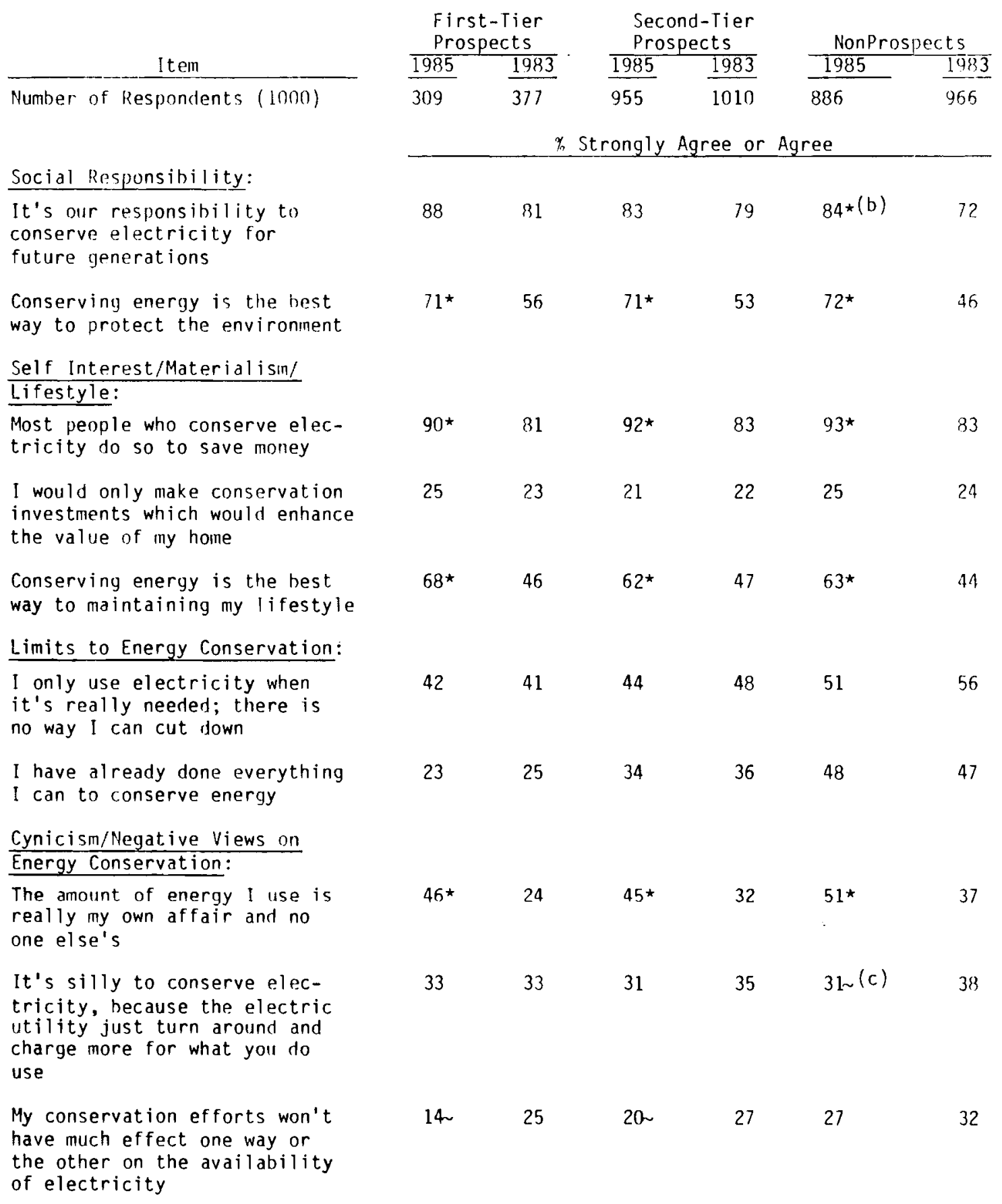

(a) The 1983 results assume that those agreeing with a statement would give one of the 4 highest scores possible, 10,9,8 and 7. These are consistent with Case $B$ in the discussion associated with Table 3.5 , Section 3.3 .

(b) An asterisk (*) indicates that the value is significantly greater than the other values at $5 \%$ significance level.

(c) A tilde $(\sim)$ indicates that the value is significantly lower than the other values at $5 \%$ significance level. 
"Most people who conserve electricity do so to save money."

"Conserving energy is the best way to maintain my lifestyle."

"The amount of energy I use is really my own affair and no one else's."

The first two statements fall into the "social responsibility" category. The next two are in the "self interest/materialism/ lifestyle" category. And the last of the above statements is in the "cynicism/ negative views on energy conservation" category. Thus, agreement with statements in the "social responsibility" and "self-interest/materialism/lifestyle" categories had become more pronounced over time.

In addition, Table 6.3 indicates that agreement with the statement "my conservation efforts won't have much effect one way or the other on the availability of electricity" was lower in 1985 than in 1983 for First- and Secondtier prospect groups. This is also consistent with the overall result discussed in Section 3.3.

For the remaining three prospect groups, there were no significant changes in the proportions of respondents agreeing with statements such as "I would only make conservation investments which would enhance the value of my home," "I only use electricity when it's really needed; there is no way I can cut down," and "I have done everything I can to conserve energy." In the Nonprospect group, the proportion agreeing with the statement "it's silly to conserve electricity, because the electric utility just turns around and charges more for what you do use" declined from $38 \%$ in 1985 to $31 \%$ in 1985.

Table B.37 (Appendix B) presents the results of significance testing separately for 1.983 and 1985 data. The following results are important for determining the prospect groups:

- The two statements in the "limits to energy conservation" category are most useful in separating prospects from nonprospects. Data from both the 1983 and 1985 surveys showed that respondents in the Nonprospect group are more likely than those in the First and Secondtier prospect groups to agree with the statements "I only use electricity when it's really needed: there is no way I can cut down." In 
1983, the same is also true for the statement "I have done everything I can to conserve energy."

- For both surveys, the following three statements are not very useful in separating respondents among the three prospect groups: "Most. people who conserve electricity do so to save money." "I would only make conservation investments which would enhance the value of my home." "Conserving energy is the best way to maintaining my lifestyle." "It's silly to conserve electricity, because the electric utility just turns around and charges more for what you do use."

- Three of the remaining four statements were useful in a limited manner in separating respondents among the three prospect groups in 1983. However, this was no longer true in 1985. The other statement yielded significant results for 1985: A larger proportion of the Nonprospect group (27\%) than that of the First-tier prospect (14\%) agreed with the statement, "My conservation efforts won't have much effect one way or the other on the availability of electricity."

- In 1983, compared to the First- and Second-tier prospect groups, the Nonprospect group had a smaller proportion of those who agreed with the statement "It's our responsibility to conserve electricity for future generations," and the statement "conserving energy is the best way to protect the environment." In 1985, no significant difference was observed.

- In 1983, compared to either the Second-tier prospect and Nonprospect groups, the First-tier prospect group had a smaller proportion of those who agreed with the statement "The amount of energy I use is really my own affair and no one else's." In 1985, no significant difference was observed.

- In 1985, compared to the First-tier prospect group, the Nonprospect group had a larger proportion of respondents who agreed with the statement "My conservation effort won't have much effect one way or the other on the availability of electricity." 
In summary, the less likely a respondent is to agree with either one of the two "limits to energy conservation" statements, the more likely he or she will be in the First-tier or Second-tier prospect groups for energy conservation investments. There were also some changes in the psychographic profiles in the sense that agreement with 3 of the 5 statements in the "social responsibility" and "self-interest/materialism/lifestyle" categories, and 1 in the 3 statements in the "cynicism/negative views on energy conservation category" had intensified between 1983 and 1985 for all three prospect groups. There were also some decreases in proportion of respondents who agreed with the statement that "my conservation efforts won't have much effect one way or the other on the availability of electricity."

\subsection{PERCEPTIONS OF INSTITUTIONS OF PROSPECT GROUPS}

In this section, the overall impressions of the respondents on energy institutions by prospect group are presented first. It is followed by a discussion of the perception of believability of energy institutions, entities and individuals as sources of energy conservation information. The 1985 data for energy institutions are measured in terms of only the respondents who were familiar with the specific energy institutions in question. (a)

\subsubsection{Overall Impressions}

Table 6.4 compares the 1985 results on overall impressions of energy institutions with 1983 results. Among those who were familiar with the Northwest Power Planning Council, the proportions of respondents who rated the institution as very favorable or favorable rose significantly for all three prospect groups from 1983 to 1985. With respect to the BPA, there was also a significant increase in the corresponding proportion for the first-tier prospect group.

In 1983, the Nonprospect group had a significantly smaller proportion than the First- and Second-tier groups who regarded the state energy office as very favorable or favorable. Similarly in 1983, the Nonprospect group had a lower proportion than the Second-tier prospect group who regarded the Northwest Power

(a) This is necessitated by the skip pattern in the survey instruments. 
TABLE 6.4. Overall Impression of Energy Institutions by Prospect Group: Comparison with 1983 Results

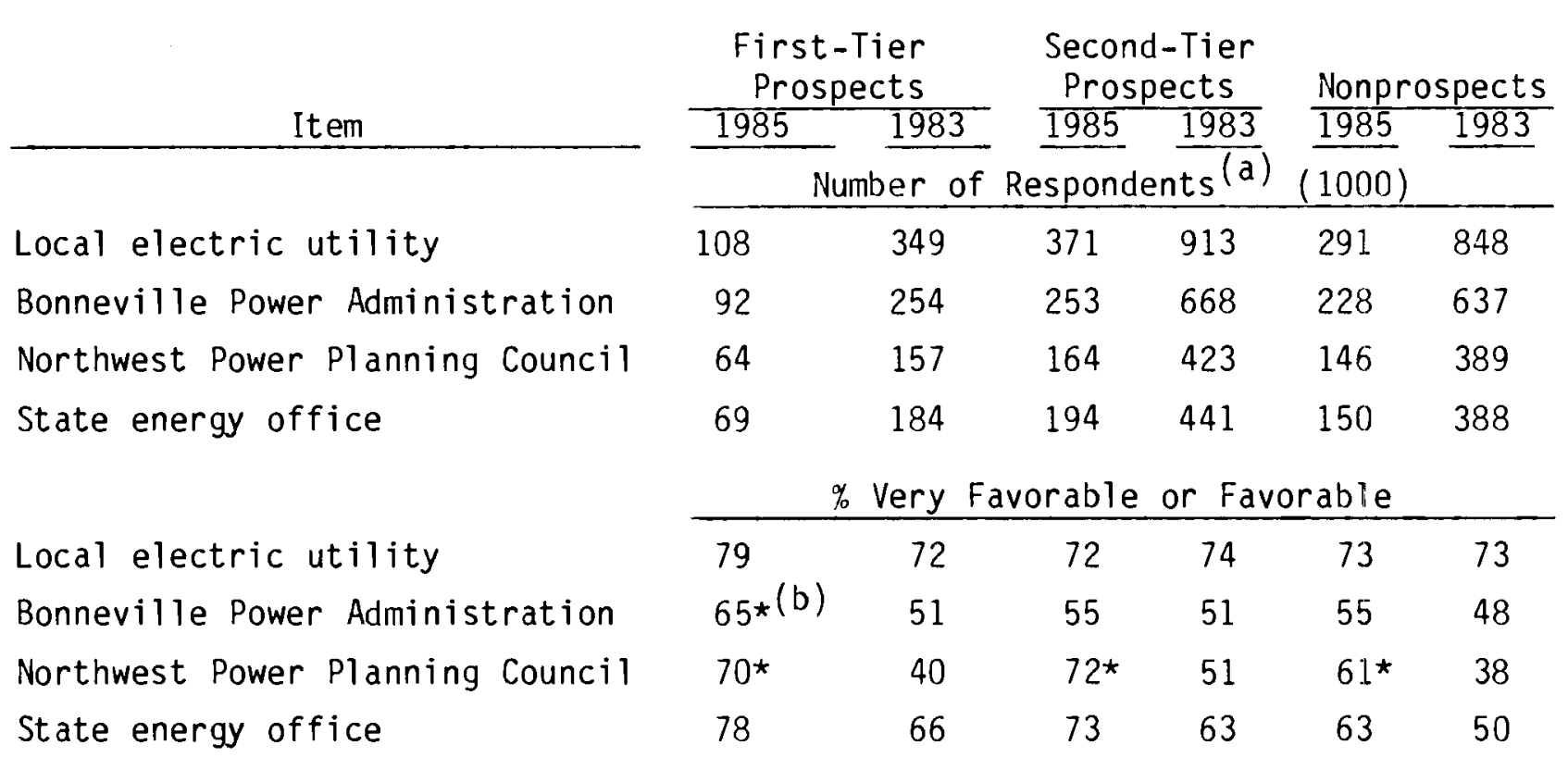

(a) Includes only those respondents in each prospect group who were familiar with the specific institutions in questions.

(b) An asterisk indicates that the value is significantly greater than the others at $5 \%$ significance level.

Planning Council as very favorable or favorable. In 1985, the First-tier prospect group had a larger proportion of respondents who regarded the local electric utility very favorably and favorably than the Second-tier prospect group (Table B.38, Appendix B). Note that other items not specifically mentioned above did not yield significant difference.

6.4.2 Believability

The data concerning the believability of energy institutions as sources of energy conservation information by prospect group are summarized in Table 6.5 and Table B.39 in Appendix B. The corresponding data for other entities and individuals not dealing directly with energy matters are summarized in Table 6.6 and Table B.40 in Appendix B. The following can be noted:

- Between 1983 and 1985, there was, for all three prospect groups, a significant decrease in the proportions of respondents who regarded 
TABLE 6.5. Believability of Energy Institutions as Sources of Energy Conservation Information by Prospect Group, 1985 Versus 1983

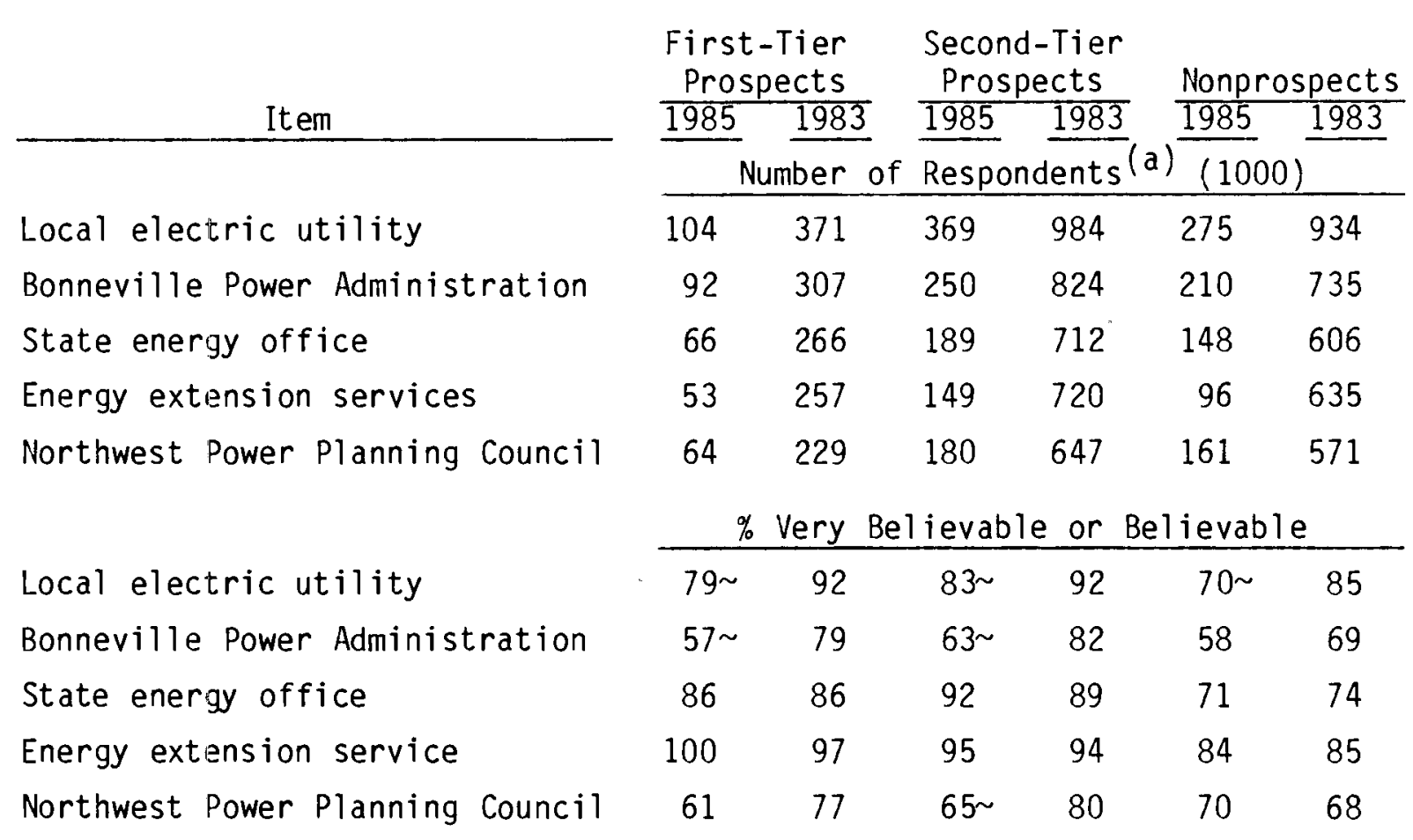

(a) Includes only those respondents in each prospect group who were familiar with the specific institutions in question.

the local electric utility as very believable or believable. For the $B P A$, the decreases in the applicable proportions occurred for the First-tier and Second-tier prospect groups (Table 6.5).

- Compared to the First- and Second-tier prospect groups, but particularly with respect to the Second-tier prospect group, the Nonprospect group is less likely to regard the energy institutions as believable sources for energy conservation information. This was even more evident in 1983 than in 1985 (Table B.39, Appendix B).

- Believability ratings of local elected officials and building contractors decreased for all three prospect groups between 1983 and 
TABLE 6.6. Believability of Other Entities and Individuals as Source of Energy Conservation Information by Prospect Group, 1985 Versus 1983

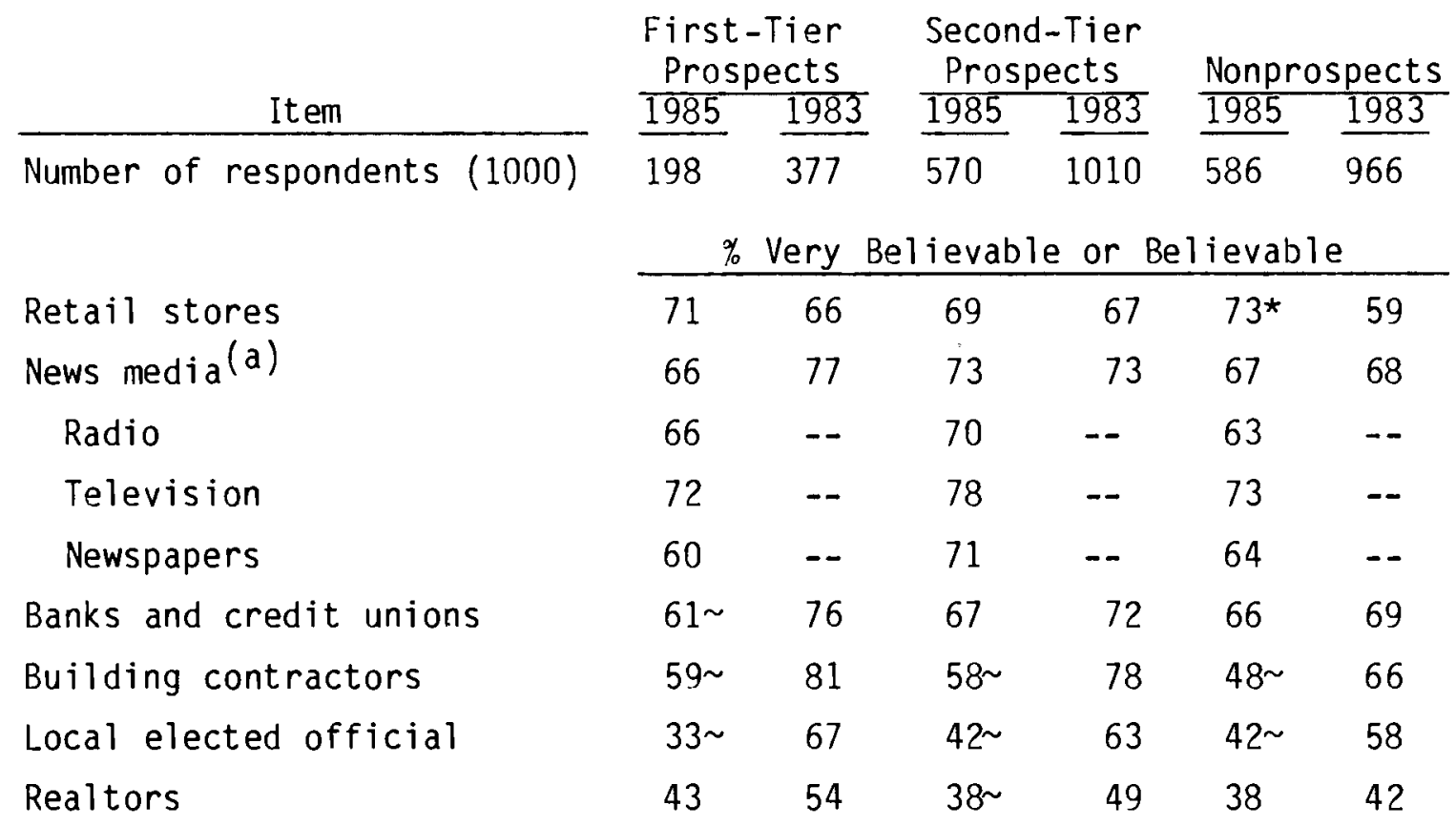

(a) Values for 1985 are simple averages of radio, television, and newspapers.

1985, similar to the trend for the overall sample noted in Sec-

tion 4.5. In the case of banks and credit unions, only the first-

tier prospect group showed significantly lower ratings. For retail

stores, the Nonprospect groups showed a significant increase. There

were no significant differences between 1983 and 1985 for news media

for each prospect group (Table 6.6).

- In 1983, the Nonprospect group gave significantly lower believability ratings to building contractors and realtors (compared to both Firstand Second-tier prospect groups), retail stores (compared to the Second-tier prospect group), and local elected officials (compared to the First-tier prospect group). In 1985, there were no significant differences among prospect groups in the believability ratings they 
gave to other entities and individuals. Building contractors is the only exception: Nonprospect groups had a smaller proportion than had the Second-tier prospect group (Table B.40, Appendix B).

\subsection{ENERGY CONSERVATION ACTIONS OF PROSPECT GROUPS}

Three topic areas are covered in this Section. First, the methods preferred by the respondents to conserve energy in the home is discussed. Second, past no/low cost conservation actions by the respondents in the three prospect groups are compared and discussed. Then past installations of ECMs are explained.

\subsubsection{Preferred Methods for Conserving Energy}

Table 6.7 presents a comparison of the 1985 and 1983 data on the preferred methods for conserving energy in the home by prospect group. It suggests that the proportions of respondents who preferred to spend money on improvements increased significantly from 1983 to 1985 for the First-tier prospect group (from $31 \%$ to $48 \%$ ) and Second-tier prospect group (from $30 \%$ to $38 \%$ ). In contrast, for the Nonprospect group, the proportion of those preferring both changing their way of living and spending money on improvements decreased significantly from $13 \%$ in 1983 to $6 \%$ in 1985.

Tests performed separately on the 1985 data suggest that, compared to the First- and Second-tier prospect groups, the Nonprospect respondents were more

TABLE 6.7. Preferred Methods for Conserving Energy by Prospect Group, 1985 Versus 1983

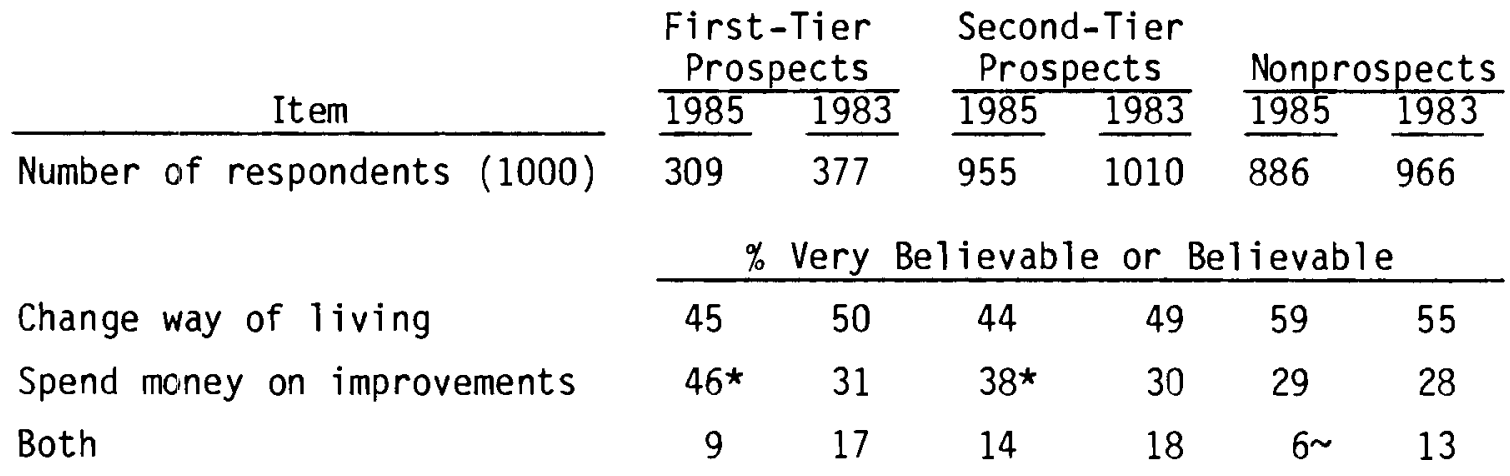


likely to prefer changing their way of living to conserve energy and less likely to prefer spending money on home improvements to do so. This is probably due to fact that the Nonprospect respondents are more likely to be in the lower income group, as noted above in Section 6.2. Tests for both 1985 and 1983 data reveal that the Nonprospect respondents were less likely than the Second-tier prospect respondents to prefer "both" (Table B.41 in Appendix B).

\subsubsection{No/Low Cost Energy Conservation Actions}

Data suggest that, compared to the respondents in First-and Second-tier prospect groups, respondents in the Nonprospect group were less likely to regularly practice no/low cost energy conservation actions, except in the case of putting plastic over their windows. Data for both 1985 and 1983 support this generalization for the following actions: lowering thermostat setting during the heating season, selecting energy efficient appliances when purchasing new ones, installing water flow restrictors in the showers, receiving a home energy audit, and wrapping water heaters. Data for 1983 survey also support this generalization for controlling lights with dimmer switches and timers, and using shades and drapes for heating and cooling (Table B.42 in Appendix B).

For all three prospect groups, significant decreases occurred between 1983 and 1985 in the proportions of respondents who regularly selected energy efficient appliances when buying new ones and for those who regularly put plastic over their windows. As noted in Section 6.2, one contributing factor for the significant decrease in the proportion of respondents who regularly put plastic over their windows was the change in wording from "putting up storm windows" in 1983 to "putting plastic over windows" in 1985. For the First-tier prospect group, the data also indicated that the proportion of those who regularly controlled their lights with dimmer switches and timers became significantly lower in 1985 at 42\%, compared with 57\% in 1983. For the Nonprospect group, the proportion of those who regularly used shades and drapes to aid in heating or cooling rose from $83 \%$ in 1983 to $88 \%$ in 1985 (Table 6.8). 
TABLE 6.8. No/Low Cost Energy Conservation Actions by Prospect Group, 1985 Versus 1983

\begin{tabular}{|c|c|c|c|c|c|c|}
\hline & $\begin{array}{l}\text { First } \\
\text { Pros }\end{array}$ & $\begin{array}{l}\text { rier } \\
\text { ects }\end{array}$ & $\begin{array}{r}\text { Secon } \\
\text { Pros }\end{array}$ & $\begin{array}{l}\text {-Tier } \\
\text { ects }\end{array}$ & Nonpr & spects \\
\hline Item & 1985 & 1983 & 1985 & 1983 & 1985 & 1983 \\
\hline Number of respondents $(1000)$ & 309 & 377 & 955 & 1010 & 886 & 966 \\
\hline & & $\% F$ & gularl & Pract & cing & \\
\hline $\begin{array}{l}\text { Control lights with dimmer } \\
\text { switches and times }\end{array}$ & $42 \sim$ & 57 & 50 & 50 & 45 & 44 \\
\hline Lower thermostat setting & 92 & 86 & 84 & 83 & 77 & 76 \\
\hline $\begin{array}{l}\text { Select energy efficient } \\
\text { appliances }\end{array}$ & $71 \sim$ & 84 & $66 \sim$ & 77 & $56 \sim$ & 67 \\
\hline $\begin{array}{l}\text { Use shades for heating and } \\
\text { coolings }\end{array}$ & 92 & 91 & 89 & 92 & $88 \sim$ & 83 \\
\hline $\begin{array}{l}\text { Install water flow } \\
\text { restrictors }\end{array}$ & 45 & 44 & 40 & 41 & 29 & 33 \\
\hline Put plastic over windows & $36 \sim$ & 65 & $24 \sim$ & 67 & $27 \sim$ & 69 \\
\hline Receive an energy audit & 29 & 32 & 37 & 34 & 28 & 25 \\
\hline Wrap water heater & 67 & 72 & 70 & 66 & 58 & 59 \\
\hline
\end{tabular}

\subsubsection{Investment-Type Energy Conservation Measures}

Table 6.9 compares the proportions of homes between 1983 and 1985 equipped with the specific investment-type ECMs by prospect group. (a) The following can be observed:

- The proportion of homes equipped with wood stove/furnace decreased significantly from 1983 to 1985 for all three prospect groups. As discussed earlier in Section 5.3, these decreases can be partially explained by the explicit introduction of fireplace inserts in the 1985 survey, eliminating the possibility, occurred in the 1983

(a) The data collected in the 1983 survey can be viewed as homes equipped with specific ECMs (see Fang 1985 p. 3.1 through 3.8). 
TABLE 6.9. Proportions of Homes Equipped with Specific ECMs by Prospect Group, 1985 Versus 1983

\begin{tabular}{|c|c|c|c|c|c|c|}
\hline & $\begin{array}{r}\text { First } \\
\text { Pros } \\
\end{array}$ & $\begin{array}{l}\text { ier } \\
\text { cts }\end{array}$ & $\begin{array}{r}\text { Secon } \\
\text { Pros } \\
\end{array}$ & $\begin{array}{l}\text { Tier } \\
\text { cts }\end{array}$ & Nonpr & pects \\
\hline Item & 1985 & 1983 & 1985 & 1983 & 1985 & 1983 \\
\hline Number of respondents $(1000)$ & 309 & 377 & 955 & 1010 & 886 & 966 \\
\hline & & $\%$ & urrent & Equi & ped & \\
\hline Roof/attic insulation & 89 & 83 & $93^{\star}$ & 83 & $91^{\star}$ & 70 \\
\hline Wall insulation & 75 & 65 & $83^{\star}$ & 71 & $79 *$ & 56 \\
\hline Weatherproofing & 77 & 70 & $84^{\star}$ & 77 & $77^{*}$ & 65 \\
\hline Storm/thermal pane windows & 69 & 67 & $83^{\star}$ & 71 & $74^{*}$ & 64 \\
\hline Storm doors & $46^{\sim}$ & 61 & $57 \sim$ & 67 & 62 & 58 \\
\hline $\begin{array}{l}\text { Floor, basement or crawlspace } \\
\text { insulation }\end{array}$ & 55 & 65 & 58 & 61 & $51^{\star}$ & 43 \\
\hline Clock or setback thermostat & 43 & 37 & $47 *$ & 35 & $37 *$ & 21 \\
\hline Wood stove/furnace & $46 \sim$ & 71 & $42^{\sim}$ & 69 & $33 \sim$ & 56 \\
\hline Fireplace insert & 24 & -- & 24 & -- & 15 & -- \\
\hline Heat pump furnace & 15 & 13 & $8 \sim$ & 14 & 8 & 6 \\
\hline
\end{tabular}

survey, that some respondents may have included a fireplace insert in their responses to the wood stove category.

- Between 1983 and 1985, significant increases occurred in the proportions of homes in both the Second-tier and Nonprospect groups equipped with roof insulation, wall insulation, weatherproofing, storm windows, and clock or setback thermostat. Floor and basement insulation showed increase from 1983 to 1985 only for the Nonprospect group. In contrast, ECMs that showed significant decreases between 1983 and 1985 included storm doors for both First-and Second-tier prospect groups and heat pump furnaces for the Second-tier group (Table 6.9). It is not clear what factors caused the decreases. 
Table $B .43$ in Appendix $B$ presents the results testing the significance between proportions separately for 1983 and 1985. The following can be noted:

- As can be expected from the manner in which the prospect groups were defined, respondents in the Nonprospect group are generally less likely than those in the First-tier and Second-tier prospect groups to have their homes equipped with the specific ECMs under consideration. This phenomenon was more evident in 1983 than in 1985, because, unlike 1983, there were no significant differences among the three prospect groups in 1985 for installing roof/attic insulation, and floor insulation.

- In 1985, the Second-tier prospect group tended to have higher proportions of respondents whose homes were equipped with outside wall insulation, weatherproofing, storm windows and clock thermostat than the other two groups, particularly compared to the Nonprospect group. In 1983, the Second-tier prospect group had higher proportions of homes equipped with weatherproofing, storm windows, and storm doors compared to the Nonprospect group.

- In 1985, significant differences occurred between the proportions of respondents in the First-tier and Second-tier prospect groups whose homes were equipped with outside wall insulation, storm windows, and heat pump furnaces.

In summary, relative to the First- and Second-tier prospect groups, the Nonprospect group had lower proportions of respondents whose homes were equipped with various ECMs. This was true for both 1983 and 1985, but more so for 1983. Compared to other groups, the Second-tier prospect group had higher proportions of homes equipped with outside wall insulation, weatherproofing, storm windows, and clock or setback thermostat. This is to be expected because, in terms of past conservation investments, the Second-tier prospect group had a larger group of respondents than the First-tier prospect group who had installed as many ECMs as respondents in the First-tier prospect group. (a)

(a) See Appendix Tables B.32 and B.33. 
Between 1983 and 1985, there were significant increases in the proportions of homes equipped with ECMs such as roof/attic insulation, wall insulation, weatherproofing, storm windows, clock or setback thermostat (Second-tier and Nonprospect), and floor insulation (Nonprospects only). There were significant decreases in the proportions of homes equipped with wood stove/furnace (all three groups), storm doors (First-and Second-tier prospects), and heat pump furnace (Second-tier prospect group only). While the decreases in the wood stove can be partially accounted for by the inclusion of the fireplace insert in the 1985 survey instrument, the decreases in storm doors and heat pump furnace cannot be easily explained.

\subsection{FINANCING SOURCES OF PROSPECT GROUPS}

The most important financing source of conservation investment for all three prospect groups is current income. This is followed by savings, banks loans and credits, utility loans, and payments by utilities. When multiple mentions of financing sources are allowed, as was the case in the 1983 survey, delay or cutbacks of other purchases and federal tax credits were also important (Table 6.10). This result is generally consistent with the overall results discussed in Section 5.5. (a)

In 1983, the Nonprospect group was less likely than the First- and Secondtier prospect groups to mention savings, delaying or cutting back on other purchases, and bank loans as financing sources of conservation investment. Otherwise, there were no other significant differences among the prospect groups in terms of financing sources in either 1983 and 1985 (Table B.44, Appendix B).(b)

\footnotetext{
(a) Note that, since the 1983 data include multiple mentions and the 1985 data do not, no attempt was made to statistically test the numerical differences of proportions between the two years.

(b) Detailed 1985 results on conservation financing are being presented and analyzed in a separate report.
} 
TABLE 6.10. Sources of Financing Conservation Investment by Prospect Group, 1985 Versus $1983($ a)

\begin{tabular}{|c|c|c|c|c|c|c|}
\hline \multirow[b]{2}{*}{ Item } & \multicolumn{2}{|c|}{$\begin{array}{l}\text { First-Tier } \\
\text { Prospects }\end{array}$} & \multicolumn{2}{|c|}{$\begin{array}{l}\text { Second-Tier } \\
\text { Prospects }\end{array}$} & \multicolumn{2}{|c|}{ Nonprospects } \\
\hline & 1985 & 1983 & 1985 & 1983 & 1985 & 1983 \\
\hline Number of respondents $(1000)$ & 309 & 377 & 955 & 1010 & 886 & 966 \\
\hline & & & & & & \\
\hline Current income & $55^{\sim}$ & 74 & $51 \sim$ & 77 & $50 \sim$ & 75 \\
\hline Savings & $16 \sim$ & 39 . & $14 \sim$ & 41 & $17 \sim$ & 35 \\
\hline $\begin{array}{l}\text { Delay or cut back other } \\
\text { purchases }\end{array}$ & $1 \sim$ & 69 & $1 \sim$ & 50 & $1 \sim$ & 36 \\
\hline Bank loans and credits & $6 \sim$ & 18 & 9 & 13 & $4 \sim$ & 12 \\
\hline Utility loan & $2 \sim$ & 10 & $2 \sim$ & 8 & $2 \sim$ & 7 \\
\hline Payments by utility & $1 \sim$ & 11 & $3 \sim$ & 9 & $3 \sim$ & 8 \\
\hline Paid by others & 1 & -- & 1 & - & 0 & -- \\
\hline Federal tax credits & $0 \sim$ & 30 & on & 23 & $1 \sim$ & 19 \\
\hline Combined sources & 0 & -- & 2 & - & 1 & -- \\
\hline Other & 1 & -- & 0 & -- & 0 & -- \\
\hline
\end{tabular}

(a) 1983 data include, while 1985 data do not include, multiple mentions.

\subsection{LIKELY FUTURE ACTIONS OF PROSPECT GROUPS}

Table 6.11 compares by prospect group the 1985 results with the 1983 results on likely future installations of ECMs. The proportions of respondents in the First-tier prospect group who indicated that they are likely to install specific ECMs remained relatively constant except for heat pump furnace which decreased from $39 \%$ to $23 \%$. In the Second-tier prospect group, only the proportion for storm doors increased from $15 \%$ to $21 \%$. There were significant decreases for roof/attic insulation, wall insulation, weatherproofing, clock or setback thermostat. For the Nonprospect group, the proportion likely to install were generally less than $2 \%$ and no test was performed. 
TABLE 6.11. Likely Installation of Energy Conservation Measures by Prospect Group, 1985 Versus 1983

\begin{tabular}{|c|c|c|c|c|c|c|c|}
\hline & $\begin{array}{c}\text { First } \\
\text { Pros }\end{array}$ & $\begin{array}{l}\text {-Tier } \\
\text { spects }\end{array}$ & $\begin{array}{r}\text { Secon } \\
\text { Pros } \\
\end{array}$ & $\begin{array}{l}\text {-Tier } \\
\text { ects }\end{array}$ & & onpr & spects \\
\hline Item & 1985 & 1983 & $\overline{1985}$ & 1983 & & 985 & 1983 \\
\hline Number of respondents $(1000)$ & 309 & 377 & 955 & 1010 & 88 & 35 & 966 \\
\hline & $\%$ & Very Li & ely or & Likely & to & Ins & al1 \\
\hline Roof/attic insulation & 9 & 13 & $3 \sim$ & 9 & & 1 & 1 \\
\hline Walls insulation & 20 & 20 & $4 \sim$ & 7 & & 0 & 0 \\
\hline Weatherproofing & 20 & 25 & $9 \sim$ & 13 & & 1 & 2 \\
\hline Storm/thermal pane windows & 26 & 27 & 10 & 14 & & 0 & 1 \\
\hline Storm doors & 37 & 31 & $21^{\star}$ & 15 & & 0 & 1 \\
\hline $\begin{array}{l}\text { Floor, basement, or crawl } \\
\text { space insulation }\end{array}$ & 26 & 17 & 12 & 14 & & 0 & 1 \\
\hline Clock or setback thermostat & 29 & 28 & $7 \sim$ & 15 & & 0 & 1 \\
\hline Wood stove/furnace & 26 & 19 & 12 & 11 & & 0 & 1 \\
\hline Fireplace insert & 25 & -- & 11 & -- & & 1 & -- \\
\hline Heat pump furnace & $23 \sim$ & 39 & 9 & 12 & & 0 & 1 \\
\hline
\end{tabular}

Table B.45 (Appendix B) shows the expected results that the First-and Second-tier prospects, and especially the First-tier generally had higher proportions of respondents who indicated they are likely to install the ECMs listed.

\subsection{DISCUSSIONS}

One of the two specific hypotheses to be tested in this report is that the size and psychographic make-up of the original three market segments found in 
the 1983 survey remain unchanged. Given the information and analyses explained above, it is now possible to summarize the results of testing this hypothesis as follows:

- When the three prospect groups are defined in the manner described in Section 6.1, which is a slight modification of the original 1983 scheme, it was shown that the size distribution of the three prospect groups remain unchanged: In $1985,10 \%$ of the respondents were in the First-tier prospect group, compared with about $12 \%$ in 1983 . Secondtier prospect group accounted for about $32 \%$ of respondents in both years. The Nonprospect group accounted for $29 \%$ in 1985 compared with $31 \%$ in 1983. Table 6.1 showed that none of the differences were not statistically significant.

- The test results for the prospect groups' psychographic make-up depended on the specific statements. In general, agreement with statements in "social responsibility" and "self interest/materialism/ lifestyle" categories, (a) and the statement that "the amount of energy I use is really my own affair and no one else's" was intensified in the sense that the proportions of respondents agreeing with these statements were significantly higher in 1985 than in 1983. There were no significant changes in the two statements in the "limits to conservation" category. There were even some decreases in the proportions of respondents agreeing with the remaining two statements in the "cynicism/negative views on energy conservation" category.

- There were also some changes in the psychographic profile of the prospect groups. In 1983, the Nonprospects were less likely to agree with the two statements in the "social responsibility" category. This was no longer the case for 1985. In 1985, Nonprospects were more likely than the Second-tier prospect groups to agree with the statement "I would only make conservation investments which would

(a) The statement "I would only make conservation investments which would enhance the value of my home" is excepted. 
enhance the value of my home." This was not the case in 1983. Similarly, in 1985, the Nonprospect group had a higher proportion than the First- and Second-tier prospect groups of respondents who agreed with the statement that my conservation efforts won't have much effect one way or the other on the availability of electricity.

Thus, it is concluded that the relative size of the three prospect groups remained relatively unchanged between 1983 and 1985. It is also concluded that there were some changes in the psychographic profiles in the sense that agreement with 3 of 5 statements in the "social responsibility" and "self-interest/ materialism/lifestyle" categories, and with 1 in 3 statements in the "cynicism/ negative views on energy conservation" category had intensified for all three prospect groups. There was also a decline in the proportion of respondents who agreed with the statement that "my conservation efforts won't have much effect one way or the other on the availability of electricity." 


\section{REFERENCES}

Fang, J. M. 1985. Household Attitudes Toward Energy Conservation in the Pacific Northwest: Overview and Comparisons, PNL-5405, Pacific Northwest Laboratory, Richland, Washington

RMH Research Inc. 1984a. Marketing Environment for Energy Conservation in the Pacific Northwest, prepared for the Pacific Northwest Laboratory by RMH Research, Inc., River Edge, New Jersey.

RMH Research Inc. 1984b. Marketing Environment for Solar and Heat Pump Water Heaters, prepared for the Pacific Northwest Laboratory by RMH Research, Inc., River Edge, New Jersey. 
$-$

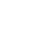


APPENDIX A

TESTING THE SIGNIFICANCE OF DIFFERENCES BETWEEN TWO PROPORTIONS 


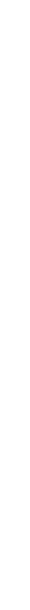


APPENDIX A

TESTING THE SIGNIFICANCE OF DIFFERENCES BETWEEN TWO PROPORTIONS

This appendix explains the statistical test of significance used in comparing proportions in different groups as well as those from 1983 and 1985. The convention used in this report to indicate whether a proportion is significantly higher or lower than the other proportion(s) is also noted.

Assume that there are two proportions $p_{1}$ and $p_{2} \cdot p_{1}$ is the proportion from sample (or subsample) 1 with a certain attribute $A_{1} P_{2}$ is the proportion from sample (or subsample) 2 with the same attribute $A$. The size of the sample is $n_{1}$ for sample 1 and $n_{2}$ for sample 2 .

The null hypothesis to be tested is that there is no significant difference between $p_{1}$ and $p_{2}$; i.e., $p_{1}-p_{2}=0$. Since there are no a priori reasons to assume that $p_{1}$ is larger than $p_{2}$ or vice versa, the alternative hypothesis is that $p_{1}$ and $p_{2}$ are different from each other, i.e. $p_{1}-p_{2} \neq 0$. This would be a two-tailed test.(a)

The relevant computations are carried out in accordance with the following equations and expressions:

$$
\begin{gathered}
\bar{p}=\frac{n_{1} p_{1}+n_{2} p_{2}}{n_{1}+n_{2}} . \\
\bar{q}=1-\bar{p} \cdot \\
s_{p_{1}}^{2}-p_{2}=\frac{\bar{p} \bar{q}}{n_{1}}+\frac{\bar{p} \bar{q}}{n_{2}} .
\end{gathered}
$$

(a) In contrast, if there is reason to believe that $p_{1}$ is higher (or lower) than $p_{2}$, then the test would be one-tailed. The null hypothes is is that $p_{1}$ is greater than $p_{2}$; i.e., $p_{1}-p_{2}>0$. The alternative hypothesis is then $p_{1}$ is not greater than $p_{2} ; i . e^{2}, p_{1}-p_{2}<0$. 
The test statistic is calculated as:

$$
z=\frac{\left(p_{1}-p_{2}\right)-0.0}{S_{p_{1}}-p_{2}}
$$

Given a $5 \%$ significance level and a two-tailed test, the critical value of the test statistic in absolute terms is 1.96 (a) Any pair of proportions with calculated $z$ less than -1.96 or greater than +1.96 is viewed as significantly different.

Example. For the proportions of respondents who were very concerned about crime, the data are as follows:

$$
\begin{aligned}
& \text { Year \% Very Concerned Sample Size } \\
& 1985 \quad p_{1}=67 \% \quad n_{1}=1058 \\
& 1983 \quad \mathrm{p}_{2}=74 \% \quad \mathrm{n}_{2}=2000 \\
& \overline{\mathrm{p}}=0.716 \\
& S p_{1}-p_{2}=0.017 \\
& z=-4.118
\end{aligned}
$$

Since -4.118 is less than -1.96 , the interpretation of the above result is that the proportion of respondents who were very concerned about crime was significantly lower in 1985 than in 1983.

Note that although the proportions presented in the report have been weighted to approximate population values, the $n$ 's used in the testing are sample sizes.

Denoting Results of Significance Testing. For convenience, the following convention has been adopted in this report for denoting the results of significance testing with respect to proportions:

(a) In a one-tailed test as explained in the previous footnote, the critical value of the test statistic at a $5 \%$ significance level is +1.645 . 
1. When there are only two proportions being tested, a significant difference between the two proportions in question will either be denoted as proportion $p_{1}$ is significantly lower than $p_{2}$, or equivalently, proportion $p_{2}$ is significantly greater than $p_{1}$. To illustrate, the result of the above example can be denoted as

$\frac{(\% \text { very concerned })}{\frac{1985}{67 \sim}} \frac{\frac{1983}{74}}{\text { crime }}$

or

$\frac{(\% \text { very concerned })}{\frac{1985}{67}} \frac{\frac{1983}{74^{\star}}}{\text { crime }}$

Note that the tilde $(\sim)$ is used to denote "significantly lower than" and asterisk $\left(^{*}\right)$ is used to show "significantly higher than."

2. When there are three proportions $\left(p_{1}, p_{2}, p_{3}\right)$ being tested, pairwise comparisons were carried out in three ways: $p_{1}$ and $p_{2} ; p_{1}$ and $p_{3} ; p_{2}$ and $\mathrm{p}_{3}$.

a. If none of the three pairs yielded significant results, neither nor * would appear in the tables, as shown in the following example:

\begin{tabular}{|c|c|c|c|}
\hline \multirow[b]{4}{*}{ Coct of Cororiog } & \multicolumn{3}{|c|}{ Age } \\
\hline & $\begin{array}{c}\text { Under } \\
34\end{array}$ & $\begin{array}{r}35- \\
54\end{array}$ & $\begin{array}{c}\text { Over } \\
55\end{array}$ \\
\hline & $(\%)$ & conc & d) \\
\hline & 44 & 42 & 45 \\
\hline
\end{tabular}

b. If only one of three pairs yielded significant result, then $\sim$ and * would appear together, as shown in the following example: 


\begin{tabular}{|c|c|c|}
\hline \multicolumn{3}{|c|}{ Income } \\
\hline Under & $\$ 16 \mathrm{~K}-$ & Over \\
\hline$\$ 16 \mathrm{~K}$ & $\$ 30 K$ & $\$ 30 \mathrm{~K}$ \\
\hline
\end{tabular}

$$
\text { Cost of Energy 59* } 51 \quad 47^{\sim}
$$

c. If two of the three pairs yield significant results, then either $\sim$ or * would be used with one of the three proportions to show that it is larger than $\left(^{*}\right)$ or smaller than $(\sim)$ the other two proportions. For example:

\begin{tabular}{|c|c|c|}
\hline \multicolumn{3}{|c|}{ Age } \\
\hline $\begin{array}{c}\text { Under } \\
34\end{array}$ & $\begin{array}{r}35- \\
54\end{array}$ & $\begin{array}{c}\text { Over } \\
55\end{array}$ \\
\hline$(\%$ & con & \\
\hline 47 & 51 & $63^{\star}$ \\
\hline
\end{tabular}

Inflation $47 \quad 5163 *$

Energy Use in the Home $41 \quad 39 \quad 28^{\sim}$

d. If all three pairs yield significant results, then the \# symbol is attached to all three proportions to show significant differences on all three pairwise comparisons. The following example is given:

\begin{tabular}{|c|c|c|}
\hline \multicolumn{3}{|c|}{ Income } \\
\hline $\begin{array}{l}\text { Under } \\
\$ 16 \mathrm{~K}\end{array}$ & $\begin{array}{l}\$ 16 K- \\
\$ 30 K\end{array}$ & $\begin{array}{l}\text { Over } \\
\$ 30 \mathrm{~K}\end{array}$ \\
\hline$(\%$ & \multicolumn{2}{|c|}{ concerned) } \\
\hline 41 & 39 & $28 \sim$ \\
\hline
\end{tabular}

\begin{tabular}{|c|c|c|}
\hline \multicolumn{3}{|c|}{ Income } \\
\hline Under & $\$ 16 \mathrm{~K}-$ & Over \\
\hline$\$ 16 \mathrm{~K}$ & $\$ 30 K$ & $\$ 30 \mathrm{~K}$ \\
\hline \multicolumn{3}{|c|}{ (\% very concerned) } \\
\hline $60 \#$ & $46 \#$ & $30 \#$ \\
\hline
\end{tabular}


APPENDIX B

DETAILED 1985 DATA AND DISCUSSIONS 


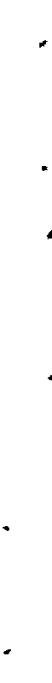


APPENDIX B

DETAILED 1985 DATA AND DISCUSSIONS

This appendix presents detailed supporting data for the 1985 survey results that have been discussed in the text. The data have been arranged in the sequence they are treated in the text. Text is also included to highlight the information contained in the tables and not otherwise discussed in the main body of this report.

As explained in Appendix A, the following convention is used in the tables to indicate the results of significance testing among the proportions:

- An asterisk (*) indicates that the value is significantly higher than the other values at a $5 \%$ significance level.

- A tilde $(\sim)$ indicates that the value is significantly lower than the other values at a $5 \%$ significance level.

- A pound sign (\#) indicates that there are significant differences among any pairs of values formed from 3 values.

\section{B.1 SUPPORTING DATA FOR CHAPTER 1.0}

Table B.1 compares the characteristics of the 1985 sample with that of the 1983 sample, covering demographic information, building characteristics and economic conditions.

\section{B.2 SUPPORTING DATA FOR CHAPTER 3.0}

Tables B.2 and B.3 present the cross tabulations of the verbatim responses for the meaning of the term "energy conservation" by age, sex, income and education of the respondents. 
TABLE B.1. Comparison of Sample Characteristics

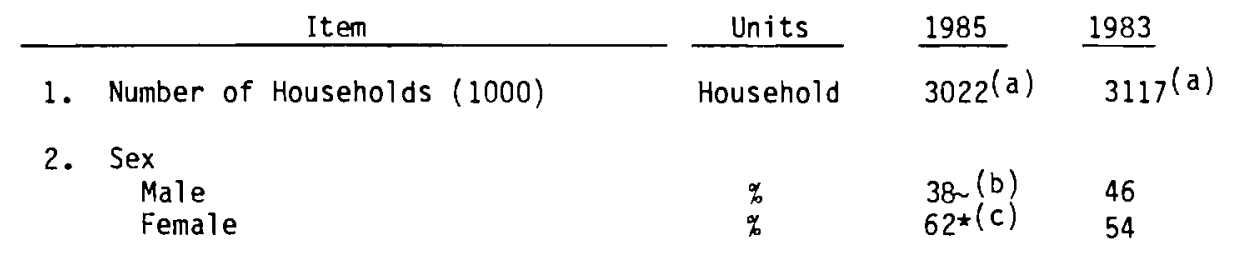

3. Age

$18-24$
$25-34$
$35-44$
$45-54$
$55-64$
Refused/missing

$\%$

$\begin{array}{ll}99^{\star} & 7 \\ 25 & 28 \\ 23 & 23 \\ 14 & 12 \\ 13 & 13 \\ 1 & 4\end{array}$

4. Education

High school or less Some college or more

5. Occupation Professional Executive/administrative Clerical-sales-technicians Crafts-foreman Other employed Not applicable/refused

$\begin{array}{lll}\% & 17 & 16 \\ \% & 11 & 9 \\ \% & 17^{\star} & 7 \\ \% & 7 \sim & 15 \\ \% & 16 & 17 \\ \% & 33 & 36\end{array}$

6. Income

Under $\$ 16 K$

$\$ 16-30 K$

Over $\$ 30 \mathrm{~K}$

$\begin{array}{lll}\% & 25 & 24 \\ \% & 36 & 39 \\ \% & 32^{\star} & 27\end{array}$

7. Own/Rent

Own

$\%$

$71 \sim$

29*

76

8. Length of Stay at Current Address Under 1 year

$1-2$ years

3-4 years

Over 5 years

$\begin{array}{lll}\% & 23 * & 10 \\ \% & 10 & 15 \\ \% & 12 \sim & 16 \\ \% & 55 & 58\end{array}$

9. Type of Dwelling

Single Family

Building with 2-4 units

Building with more than 4 units

Mobile home/other

$\begin{array}{rrr}\% & 76 & 76 \\ \% & 9 & 8 \\ \% & 7 & 8 \\ \% & 8 & 7\end{array}$

10. Primary Heating Fue 1
Electricity
Wood
Natural Gas
$0 i 1$
LP gas
Solar
Other

$\begin{array}{rrr}\% & 38 & 37 \\ \% & 29 & 28 \\ \% & 19 & 20 \\ \% & 11 & 11 \\ \% & 2 & 3 \\ \% & 0 & 0 \\ \% & 0 & 0\end{array}$


TABLE B.1. (contd)

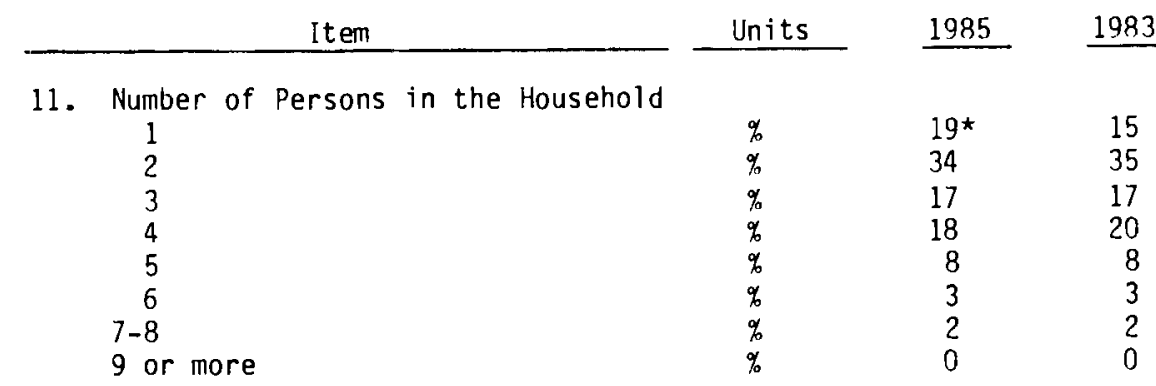

(a) These numbers should not be interpreted to mean that there was a decrease in the number of total households in the region from 1983 to 1985. They simply reflected different estimates of 1980 total households in the BPA service area, both based on the 1980 Census. The 1983 figure was developed by RMH Research, Inc. (1984a, p. vi vii) while the 1985 figure was developed by Columbia Research Center (see discussion in Chapter 1 of this report). It was necessary to use the 1980 Census data because county by county household data was required to develop the weights for each of the four geographic divisions. Since most of the substantive discussions in this report are in terms of proportions of the total households or home owners, the findings should not be affected by the absolute values of the estimates.

(b) A tilde $(\sim)$ indicates that the value is significantly lower than the other values at a $5 \%$ significance level.

(c) A asterisk (*) indicates that the value is significantly higher than the other values at a $5 \%$ significance level.

Tables B.4 and B.5 provide data on the proportions of respondents who were very concerned about various issues by age, sex, income and education of the respondents.

Tables B.6 and B.7 summarize the results on the psychographic profiles of the respondents with respect to 15 statements concerning energy use and conservation by age, sex, income and education of the respondents. The 15 statements have been grouped into four categories: social responsibility, selfinterest/materialism/lifestyle, limits to energy conservation, and cynicism/negative views on energy conservation. The following interpretations of the results are grouped into these four categories.

Social Responsibility

The proportions of respondents agreeing with two social responsibility statements were affected by sex or education, but not by age and income. Males and the more educated respondents were less likely to agree that "it is our 
TABLE B.2. Understanding the Term "Energy Conservation" by Age and by Sex, 1985

\begin{tabular}{|c|c|c|c|c|c|c|}
\hline & & & Age & & & \\
\hline Item & $\begin{array}{c}\text { Al1 } \\
\text { Respondents }\end{array}$ & $\begin{array}{l}\text { Under } \\
34\end{array}$ & $\begin{array}{r}35- \\
54\end{array}$ & $\begin{array}{l}\text { Over } \\
55\end{array}$ & $\frac{\mathrm{Se}}{\mathrm{MaTe}}$ & $\frac{x}{\text { FemaTe }}$ \\
\hline Base: Total Households (1000) & 3022 & 1022 & 1156 & 801 & 1143 & 1880 \\
\hline Conserve/Save Energy & $85 \%$ & $85 \%$ & $87 \%$ & $84 \%$ & $82 \%$ & $87 \%$ \\
\hline $\begin{array}{l}\text { use energy intelligently/ } \\
\text { efficiently }\end{array}$ & 40 & 41 & 41 & 38 & 40 & 40 \\
\hline use less electricity & 26 & 27 & 25 & 26 & 23 & 27 \\
\hline conserve natural resources & 13 & 10 & 14 & 14 & 13 & 12 \\
\hline use only as much as needed & 6 & 6 & 6 & 5 & 5 & 6 \\
\hline use less oil & 0 & 1 & 0 & 0 & 1 & 0 \\
\hline protect/save water & 0 & 0 & 1 & 0 & 0 & 1 \\
\hline Specific Conservation Actions & $1 \%$ & $1 \%$ & $1 \%$ & $1 \%$ & $1 \%$ & $\underline{1 \%}$ \\
\hline Insulate/weatherize house & 1 & 0 & 1 & 1 & 0 & 1 \\
\hline Get a small car & 0 & 0 & 0 & 0 & 0 & 0 \\
\hline Recycle & 0 & 0 & 0 & 0 & 0 & 0 \\
\hline $\begin{array}{l}\text { Use/Develop Alternative Energy } \\
\text { Sources }\end{array}$ & $3 \%$ & $3 \%$ & $2 \%$ & $3 \%$ & $\underline{2 \%}$ & $3 \%$ \\
\hline develop alternatives & 1 & 1 & 1 & 0 & 0 & 2 \\
\hline use/develop solar & 1 & 1 & 0 & 1 & 0 & 0 \\
\hline use wood as fuel & 1 & 1 & 1 & 1 & 2 & 1 \\
\hline Save Money & $\underline{0 \%}$ & $1 \%$ & $\underline{0 \%}$ & $\underline{0 \%}$ & $\underline{0 \%}$ & $\underline{0 \%}$ \\
\hline save money & 0 & 1 & 0 & 0 & 0 & 0 \\
\hline tax credits & 0 & 0 & 0 & 0 & 0 & 0 \\
\hline $\begin{array}{l}\text { Don't Know/Means Nothing/ } \\
\text { Refused }\end{array}$ & $11 \%$ & $11 \%$ & $10 \%$ & $\underline{11 \%}$ & $14 \%$ & $9 \%$ \\
\hline
\end{tabular}

responsibility to conserve electricity for future generations." Males were less likely than females to agree that conserving energy is the best way to protect the environment.

\section{Self-Interest/Materialism/Lifestyle}

The more educated were less likely to agree with the statements that "most people who conserve do so to save money" and that "I would only make 
TABLE B.3. Understanding of the Term "Energy Conservation" by Income and by Education, 1985

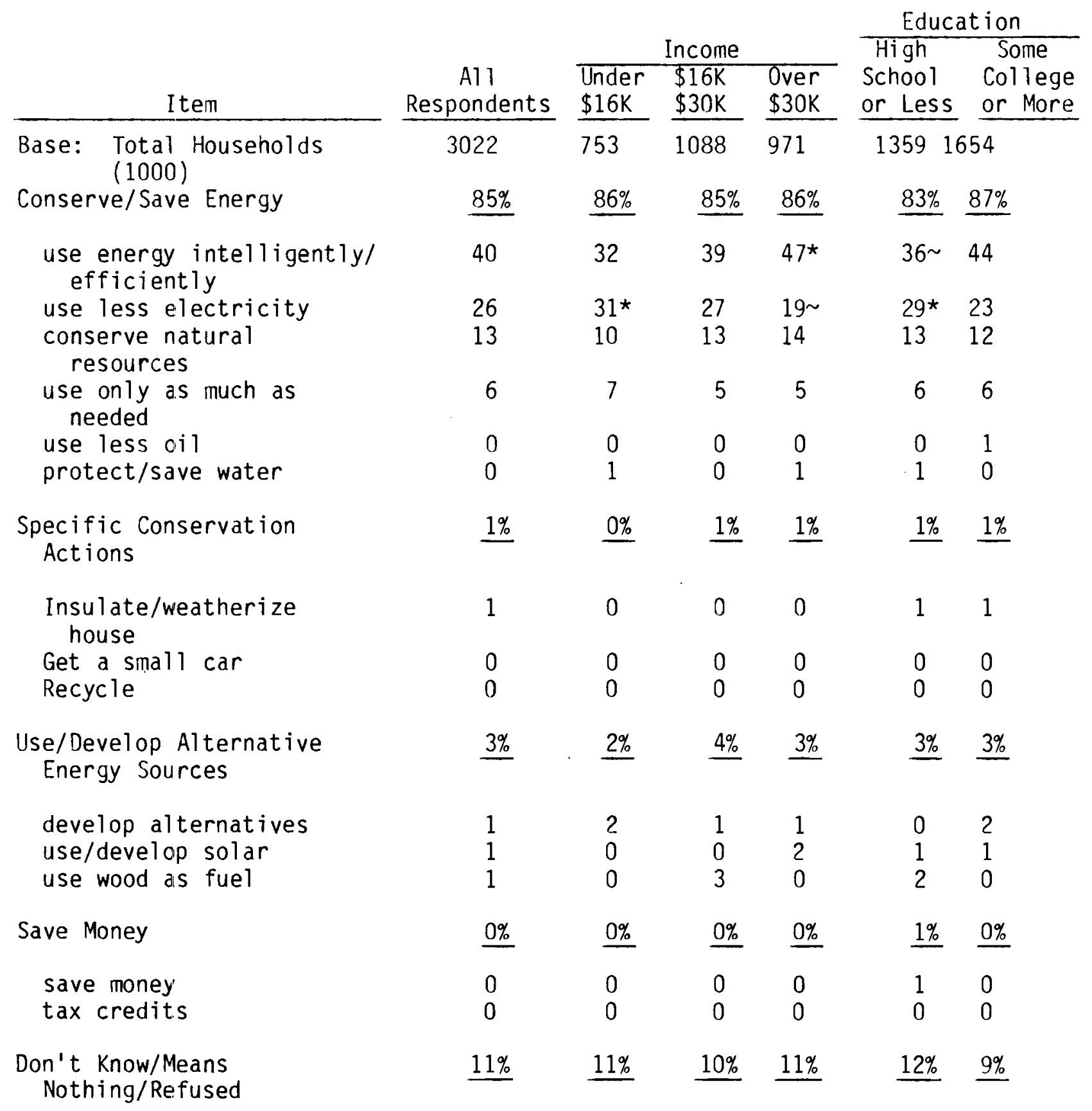


TABLE B.4. Concern About Issues by Age and by Sex, 1985

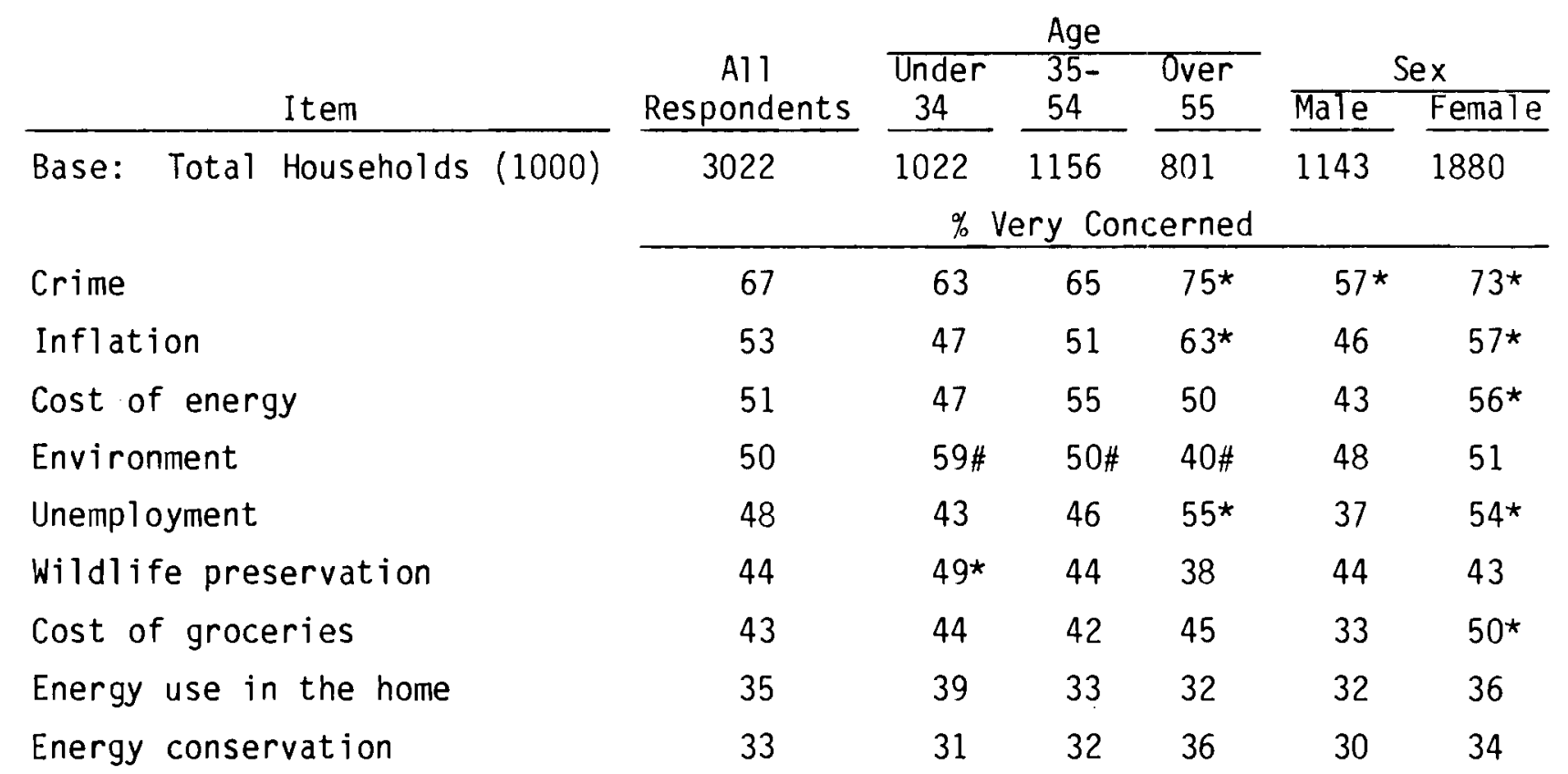

TABLE B.5. Concern About Issues by Income and by Education, 1985

\begin{tabular}{|c|c|c|c|c|c|c|}
\hline \multirow[b]{2}{*}{ Item } & \multirow{3}{*}{$\begin{array}{c}\text { Al1 } \\
\text { Respondents } \\
3022\end{array}$} & \multicolumn{3}{|c|}{ Income } & \multicolumn{2}{|c|}{ Education } \\
\hline & & \multirow{2}{*}{$\begin{array}{l}\text { Under } \\
\$ 16 K \\
753\end{array}$} & \multirow{2}{*}{$\begin{array}{l}\$ 16 \mathrm{~K} \\
\$ 30 \mathrm{~K} \\
1088\end{array}$} & \multirow{2}{*}{$\begin{array}{l}\text { Over } \\
\$ 30 \mathrm{~K} \\
971\end{array}$} & \multicolumn{2}{|c|}{$\begin{array}{lc}\text { Some } \\
\text { School College } \\
\text { Less or More }\end{array}$} \\
\hline $\begin{aligned} \text { Base: } & \text { Total Households } \\
& (1000)\end{aligned}$ & & & & & 1359 & 1654 \\
\hline Crime & 67 & $72^{\star}$ & 66 & 62 & $72^{\star}$ & 63 \\
\hline Inflation & 53 & $59 *$ & 54 & 48 & $60^{\star}$ & 47 \\
\hline Cost of energy & 51 & $59 *$ & 51 & 47 & $58 *$ & 46 \\
\hline Environment & 50 & 51 & 50 & 51 & $46 \sim$ & 54 \\
\hline Unemp loyment & 48 & $58^{\star}$ & 49 * & $38 *$ & $54^{\star}$ & 42 \\
\hline Wildlife preservation & 44 & 48 & 44 & 41 & 44 & 44 \\
\hline Cost of groceries & 43 & $60 \#$ & $46 \#$ & $30 \#$ & $51^{\star}$ & 37 \\
\hline Energy use in the home & 35 & 41 & 39 & $28 \sim$ & 39 & 32 \\
\hline Energy conservation & 33 & 36 & 32 & 31 & 33 & 33 \\
\hline
\end{tabular}


TABLE B.6. Psychographic Profile by Age and Sex, 1985

\begin{tabular}{|c|c|c|c|c|c|c|c|}
\hline & & & & Age & & & \\
\hline & & & Under & $35-$ & Over & & ex \\
\hline & Item & Respondents & 34 & 54 & 55 & Male & Female \\
\hline Base: & Total Households $(1000)$ & 3022 & 1022 & 1156 & 801 & 1143 & 1880 \\
\hline & & & Stron & ly $\mathrm{Ag}$ & e or & ree & \\
\hline
\end{tabular}

Social Responsibility

It's our responsibility to conserve electricity for future generations

$\begin{array}{llllll}85 & 86 & 87 & 85 & 81 \sim & 88\end{array}$

Conserving energy is the best way to protect the environment

$\begin{array}{llllll}73 & 74 & 74 & 72 & 68 & 77\end{array}$

Self Interest/Materialism/Lifestyle

Most people who conserve electricity do so to save money

I would on ly make conservation investments which would enhance the value of my home

I would invest in energy conservation because it increases the comfort of my home

Conserving energy is the best way to maintain my lifestyle

\section{Limits to Energy Conservation}

I only use electricity when it's really needed; there is no way I can cut down

I have al ready done everything I can to conserve energy

Cynicism/Negative Views on Energy Conservation

The amounit of energy I use is really my own affair and no one else's

It's silly to conserve electricity, because the electric utility just turns around and charges more for what you do use

My conservation efforts won't have much effect one way or the other on the availatility of electricity

Utilities should stop offering a variety of programs to encourage energy conservation

I will invest in the efficiency of my home only if there are rebates to me from the utility

Electricity prices in the Northwest are not high enough to necessitate conservation activities

With the current power surplus in the Northwest, there is no need to conserve electricity

$\begin{array}{llllll}92 & 94 & 91 & 92 & 92 & 92 \\ 25 & 25 & 23 & 26 & 25 & 24 \\ 90 & 89 & 94 \star & 87 & 89 & 91 \\ 62 & 64 & 57 \sim & 69 & 57 \sim & 66 \\ 47 & 39 \# & 46 \# & 58 \# & 44 & 48 \\ 37 & 26 & 32 & 60 * & 30 \sim & 42\end{array}$

$\begin{array}{llllll}46 & 46 & 44 & 48 & 47 & 45\end{array}$

$\begin{array}{llllll}31 & 29 & 33 & 33 & 38^{\star} & 17\end{array}$

$21 \quad 15 \quad 23 \quad 28 \quad 27$ * $\quad 18$

$\begin{array}{llllll}9 & 10 & 20 \text { * } & 10 & 14\end{array}$

$\begin{array}{llllll}12 & 15 & 10 & 13 & 12 & 12\end{array}$

$\begin{array}{llllll}8 & 9 & 7 & 8 & 11^{\star} & 6\end{array}$

$4 \quad 1 \# \quad 4 \# \quad 9 \# \quad 4 \quad 4 \quad 5$ 
TABLE B.7. Psychographic Profile by Income and Education, 1985

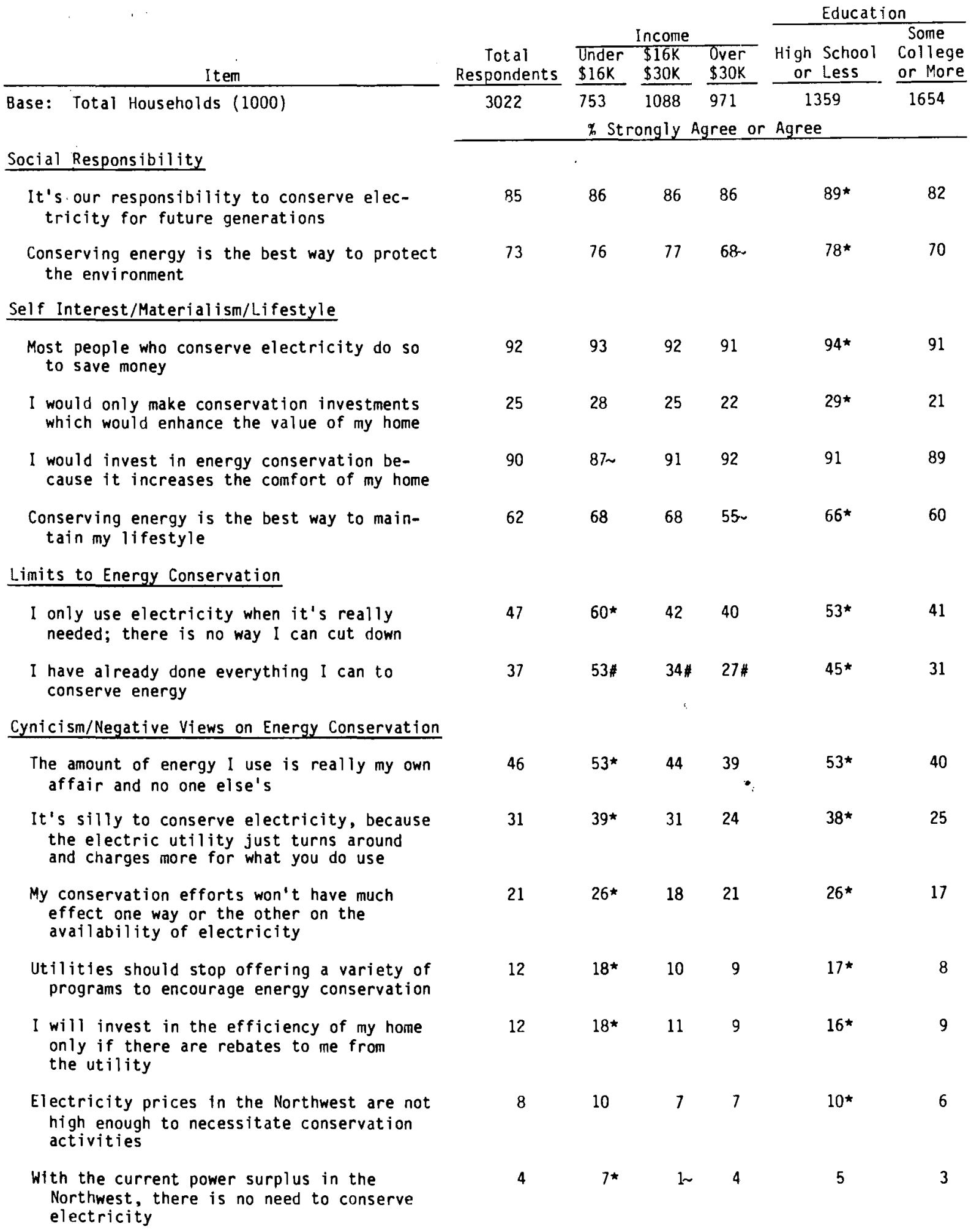


conservation investments which would enhance the value of my home." Age, sex, and income were not important in affecting people's belief in the latter aspects.

Those who are in the age bracket 35 to 54 are more likely than either younger or older respondents to agree with the statement that "I would invest in energy conservation because it increases the comfort of my home." Lower income respondents are less likely than higher income respondents to agree with this statement.

Agreement with the statement that "conserving energy is the best way to maintain my lifestyle" was affected by age, sex, income and education of respondents. 0lder respondents were more likely than those in the middle age group to agree with the statement. Female respondents were also more likely to be in agreement with the statement. Lower income, and more educated respondents were less likely to agree with it.

Limits to Energy Conservation

Agreement with statements concerning limits to conservation were affected by age, sex, income and education. Generally, the older, lower income, and the less educated respondents were more likely to agree with both statements in this category. Female respondents were also more likely than males to agree with the statement that "I have done everything to conserve energy."

Cynicism/Negative Views on Energy Conservation

The lower income and the less educated respondents were more likely to agree that "the amount of energy I use is really my own affair and no one else's." Female respondents, higher income respondents, and those with at least some college education were less likely than their respective counterparts to be in agreement with the statement that "it's silly to conserve electricity because the electric utility just turns around and charges more for what you do use."

Younger respondents, female respondents, higher income households and those with at least some college education were not as likely as the older respondents, male, lower income households and those with at most high school education to be in agreement with the statement that "my conservation efforts 
won't have much effect one way or the other on the availability of electricity." Similarly, older respondents, lower income people, and those with at most high school education were more likely than their respective counterparts to agree that utilities should stop offering a variety of programs to encourage energy conservation.

Lower income respondents and those with at most high school education were more likely to agree with the statement that "I will invest in the efficiency of my home only if there are rebates to me from the utility." Female respondents and those with at least some college education were less likely to agree with the statement that electricity prices in the Northwest are not high enough to necessitate conservation activities. Finally, older and lower income respondents were more inclined than the younger or the middle income respondents to agree that, with the current power surplus in the Northwest, there is no need to conserve electricity.

\section{B.3 SUPPORTING DATA FOR CHAPTER 4.0.}

Tables B.8 and B.9 present the 1985 data on the proportions of respondents' perception of the energy institutions' concern for the consumer by age, sex, income and education of the respondents. It appears that consumer perceptions of the energy institutions' concerns for the consumer were not affected by sex and education but were impacted by age. The younger (under 34) respondents were more likely than the older respondents (35 or older) to feel that BPA, Northwest Power Planning Council, and energy extension service were very concerned or concerned about the consumers' economic welfare. Middle income respondents were more likely than higher income respondent to regard the energy extension service as concerned about the consumer.

Tables B.10 and B.11 provide the 1985 data on the proportions of respondents who regarded the specific energy institutions as most responsible or responsible for setting electricity prices by age, sex, income and education. Sex, income and education did not appear to influence the views on which organizations responsible for setting prices. Compared to the respondents under 54 years old, the older (over 55) respondents were significantly less likely to 
TABLE B.8. Energy Institution's Concern for the Consumer by Age and Sex, 1985

\begin{tabular}{|c|c|c|c|c|c|c|}
\hline Item & $\begin{array}{c}\text { All } \\
\text { Respondents }\end{array}$ & $\begin{array}{l}\text { Under } \\
34\end{array}$ & $\begin{array}{l}\text { Age } \\
35- \\
54\end{array}$ & $\begin{array}{c}\text { Over } \\
55\end{array}$ & \multicolumn{2}{|c|}{ Sex } \\
\hline & $\%$ Ver & Conc & ned & Conc & rned ${ }^{\prime}$ & \\
\hline Local electric utility & 65 & 68 & 61 & 69 & 65 & 66 \\
\hline Public utility commission & 60 & 69 & 54 & 54 & 61 & 59 \\
\hline State energy of fice & 64 & 68 & 63 & 62 & 69 & 61 \\
\hline $\begin{array}{l}\text { Bonneville Power } \\
\text { Administration }\end{array}$ & 48 & $65^{\star}$ & 36 & 40 & 42 & 52 \\
\hline Energy extension service & 80 & $88^{\star}$ & $70 \sim$ & 82 & 79 & 80 \\
\hline $\begin{array}{l}\text { Northwest Power Planning } \\
\text { Council }\end{array}$ & 60 & $75^{\star}$ & $43 \sim$ & 61 & 55 & 64 \\
\hline WPPSS & 32 & 41 & 29 & 24 & 36 & 29 \\
\hline
\end{tabular}

(a) As proportions of those who were familiar with the specific institutions.

view the BPA, and WPPSS as responsible for setting electricity prices in the Northwest. In contrast, the under 34 age group was more likely to view the Power Council as responsible.

Tables B.12 and B.13 present the detailed data on the overall impression of energy institutions, other entities and individuals by age, sex, income and education. Age appeared to be an important factor in determining overall impressions of the energy institutions. The younger (under 34) respondents were more likely than their older counterparts to favorably regard the BPA, state energy office, and Northwest Power Planning Council. On the other hand, the older (over 55) respondents were more likely than the middle aged (35 to 54) group to regard the local utility in a favorable light (Table B.12). Middle income consumers were more likely than low income respondents to favorably regard state energy office and energy extension service (Table B.13). 
TABLE B.9. Energy Institution's Concern for the Consumer by Income and Education, 1985

\begin{tabular}{|c|c|c|c|c|c|c|}
\hline \multirow[b]{2}{*}{ Item } & \multirow[b]{2}{*}{$\begin{array}{c}\mathrm{A} 11 \\
\text { Respondents } \\
\end{array}$} & & \multicolumn{2}{|c|}{ Education } \\
\hline & & $\begin{array}{l}\text { Under } \\
\$ 16 K \\
\end{array}$ & $\begin{array}{l}\text { Income } \\
\$ 16 \mathrm{~K} \\
\$ 30 \mathrm{~K}\end{array}$ & $\begin{array}{l}\text { Over } \\
\$ 30 \mathrm{~K} \\
\end{array}$ & $\begin{array}{l}\text { High } \\
\text { School } \\
\text { or Less } \\
\end{array}$ & $\begin{array}{l}\text { Some } \\
\text { College } \\
\text { or More }\end{array}$ \\
\hline & \multicolumn{6}{|c|}{$\%$ Very Concerned and Concerned (a) } \\
\hline Local electric utility & 65 & 67 & 67 & 64 & 64 & 67 \\
\hline Public utility commission & 60 & 56 & 65 & 53 & 59 & 59 \\
\hline State energy office & 64 & 61 & 66 & 69 & 63 & 66 \\
\hline $\begin{array}{l}\text { Bonneville Power } \\
\text { Administration }\end{array}$ & 48 & 49 & 52 & 40 & 49 & 47 \\
\hline Energy extension service & 80 & 80 & $90 *$ & $69 \sim$ & 78 & 81 \\
\hline $\begin{array}{l}\text { Northwest Power Planning } \\
\text { Council }\end{array}$ & 60 & 53 & 64 & 58 & 55 & 64 \\
\hline WPPSS & 32 & 36 & 34 & 26 & 29 & 35 \\
\hline
\end{tabular}

(a) As proportions of those who were familiar with the specific institutions.

TABLE B.10. Energy Institution's Responsibility in Setting Electricity Price by Age and Sex, 1985

\begin{tabular}{|c|c|c|c|c|c|c|}
\hline \multirow[b]{3}{*}{ Item } & \multirow{3}{*}{$\begin{array}{c}\text { All } \\
\text { Respondents } \\
\end{array}$} & \multicolumn{3}{|c|}{ Age } & \multirow{2}{*}{\multicolumn{2}{|c|}{ Sex }} \\
\hline & & Under & $35-$ & Over & & \\
\hline & & & 54 & 55 & MaTe & Female \\
\hline & \multicolumn{6}{|c|}{ \% Totally Responsible and Responsible (a) } \\
\hline Local electric utility & 78 & 85 & 76 & 74 & 84 & 75 \\
\hline Bonneville Power Administration & 75 & 82 & 78 & $58 \sim$ & 72 & 76 \\
\hline Public utility commission & 72 & 76 & 72 & 66 & 73 & 71 \\
\hline WPPSS & 69 & $78^{\star}$ & 69 & $54 \sim$ & 59 & 76 \\
\hline Northwest Power Planning Council & 62 & $77 \star$ & 55 & 53 & 60 & 63 \\
\hline
\end{tabular}

(a) As proportions of those who were familiar with the specific institutions. 
TABLE B.11. Energy Institution's Responsibility in Setting Electricity Price by Income and Education, 1985

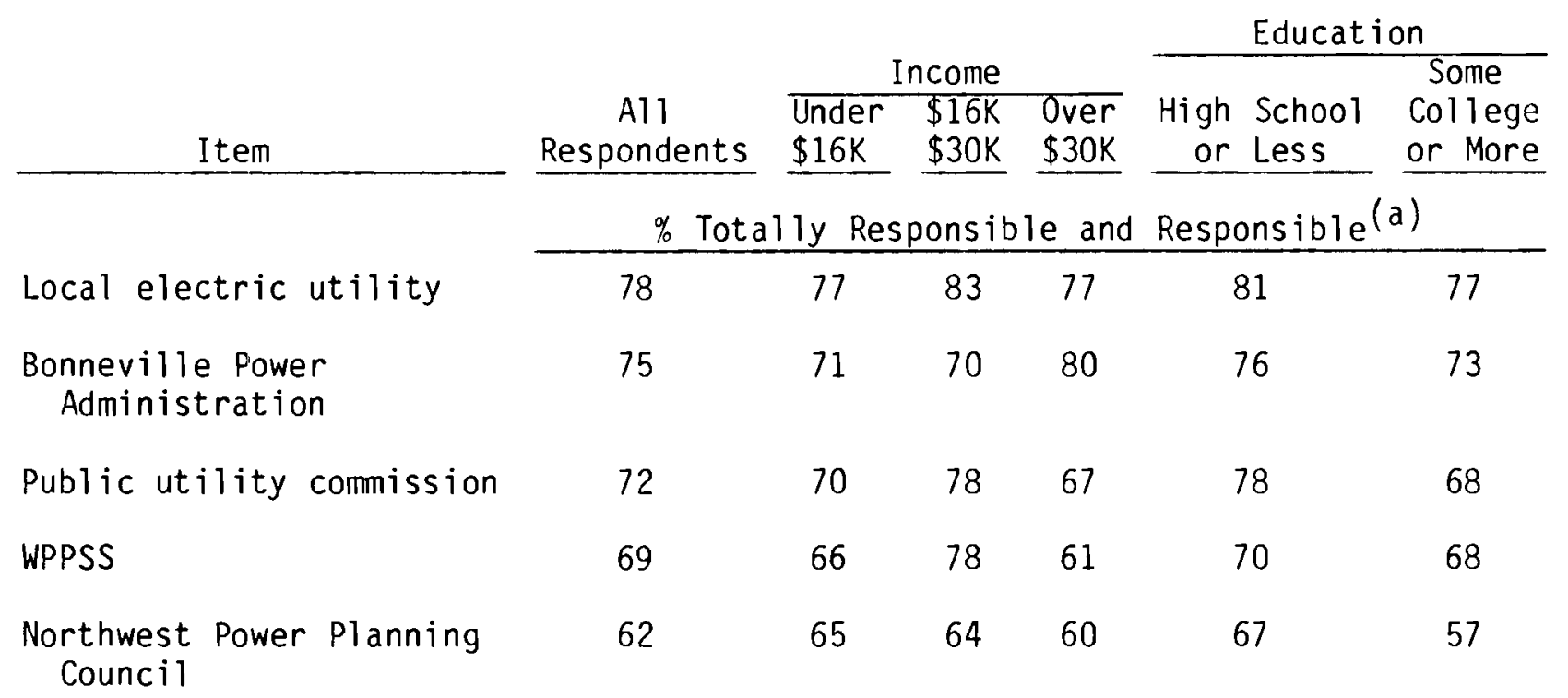

(a) As proportions of those who were familiar with the institutions.

Age, sex, income and education all affected the respondents' overall impressions of the entities and individuals not directly dealing with energy matters in some ways. The older respondents were less likely than the younger ones to view retails stores, realtors, building contractors, or the radio in the favorable light and were more likely to regard banks and credit unions favorably. Female respondents were more likely to have a favorable overall impression of banks/credit unions but were less likely to see the building contractor in that light (Table B.12).

The lower income respondents were less likely to have a favorable impression of realtors, building contractors, and the radio. Impressions of banks/credit unions, local elected officials, retail stores and newspapers were not dependent on income level. Those with at least some college education were more likely to view building contractors, retail stores in a favorable light. They were also less likely to regard television in this manner (Table B.13). 
TABLE B.12. Overall Impression of Institutions and Entities by Age and Sex, 1985

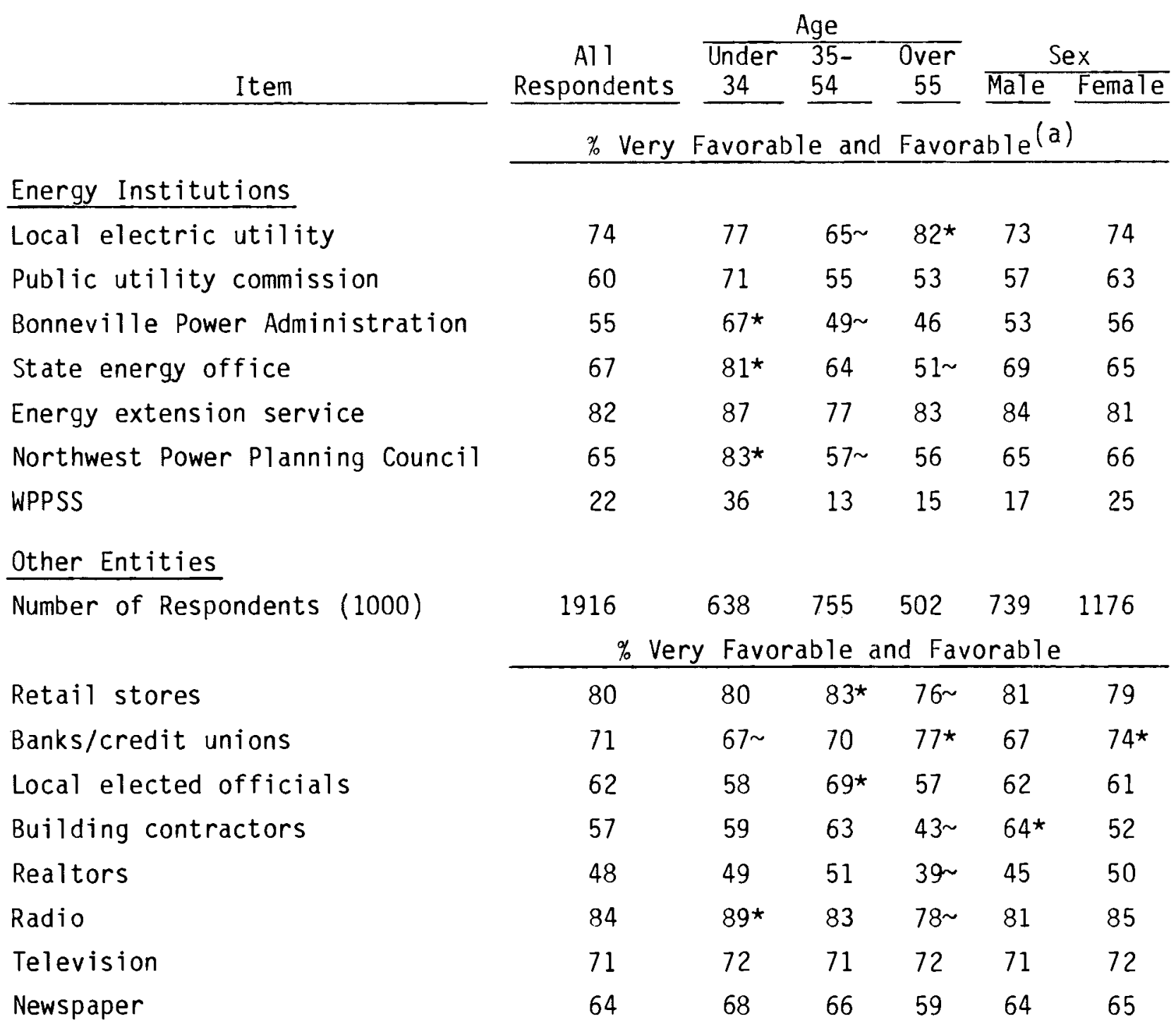

(a) As proportions of those who were familiar with the institutions.

Tables B.14 and B.15 present the detailed cross tabulations on the believability of energy institutions and other entities as a source of energy information by age, sex, education and income. Consumer perceptions of energy institutions as believable sources of information about energy conservation were significantly affected by age, sex, and income but generally not by education. Generally, the younger (under 34) respondents were more inclined 
TABLE B.13. Overall Impression of Institutions and Entities by Income and Education, 1985

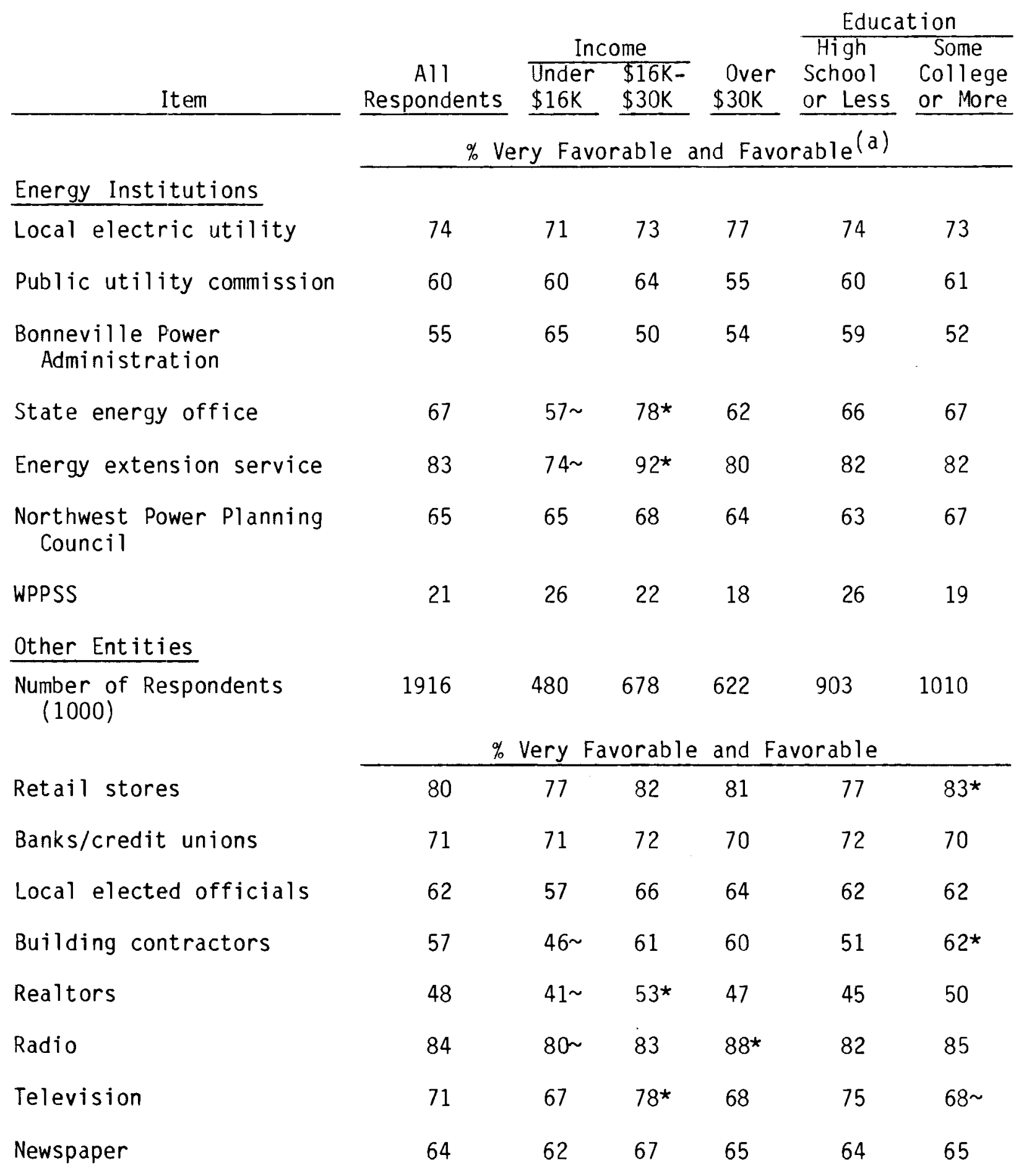

(a) As proportions of those who were familiar with the institutions. 
than the over 35 groups to view information from the BPA, state energy office, energy extension service, and the Northwest Power Planning Council as credible. Compared to male respondents, female respondents were significantly less likely to view energy conservation information from their local electric utility and state energy office as believable (Table B.14).

TABLE B.14. Believability of Institutions and Entities as Source of Energy Conservation Information by Age and Sex, 1985

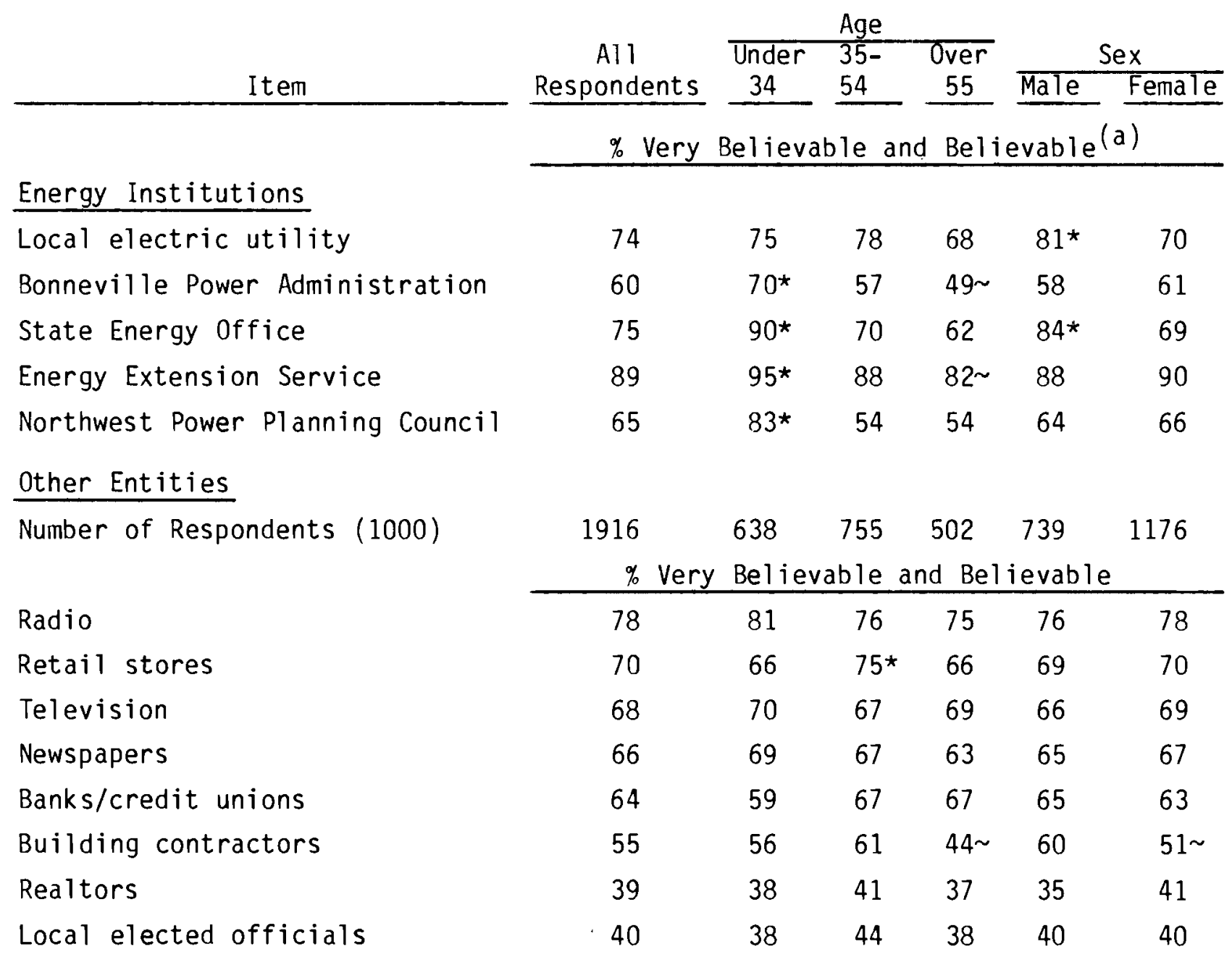

(a) As proportion of those who were familiar with the institutions. 
TABLE B.15. Believability of Institutions and Entities as Source of Energy Conservation Information by Income and Education, 1985

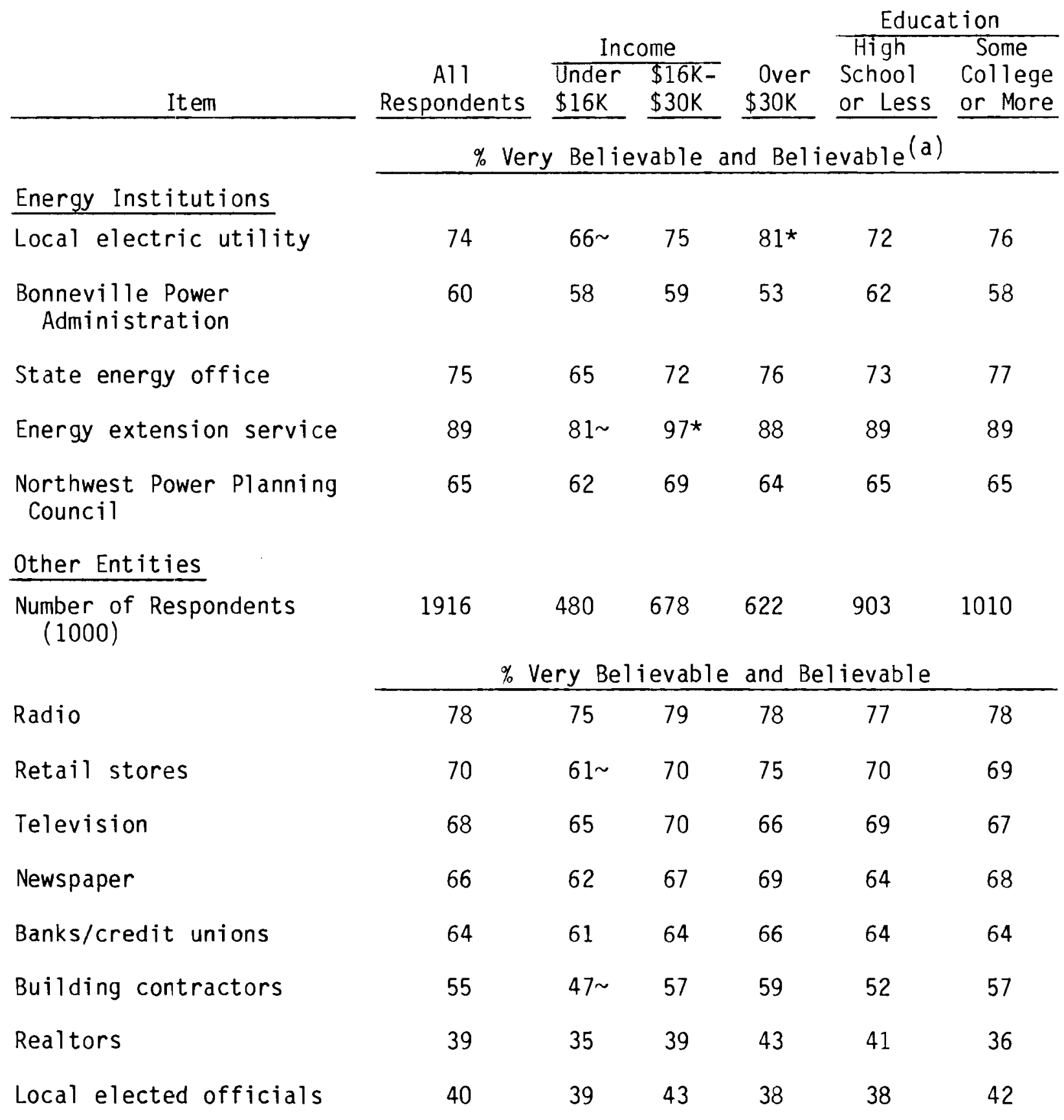

(a) As proportions of those who were familiar with the institutions. 
Perceptions concerning the believability of radio, television, banks/credit unions, and local elected officials were seldomly affected by age, sex, income and education. The older (55 and over) and female respondents appeared to be less likely than their younger counterparts to believe the energy conservation information provided by building contractors. The mid-age group (35 to 54 years) appeared more likely to accept energy conservation information from the retail stores than were the younger (under 34) respondents. Relative to male respondents, female respondents were more willing to believe information supplied by realtors and less willing to trust information from building contractors (Table B.14). The lower income respondents were less likely than their higher income counterparts to view retail stores or building contractors as credible energy conservation information sources (Table B.15).

\section{B.4 SUPPORTING DATA FOR CHAPTER 5.0}

Tables B.16 and B.17 present the cross tabulations on preferred methods of conserving energy in the home by age, sex, income, and education.

TABLE B.16. Preferred Method of Conserving Energy by Age and Income, 1985

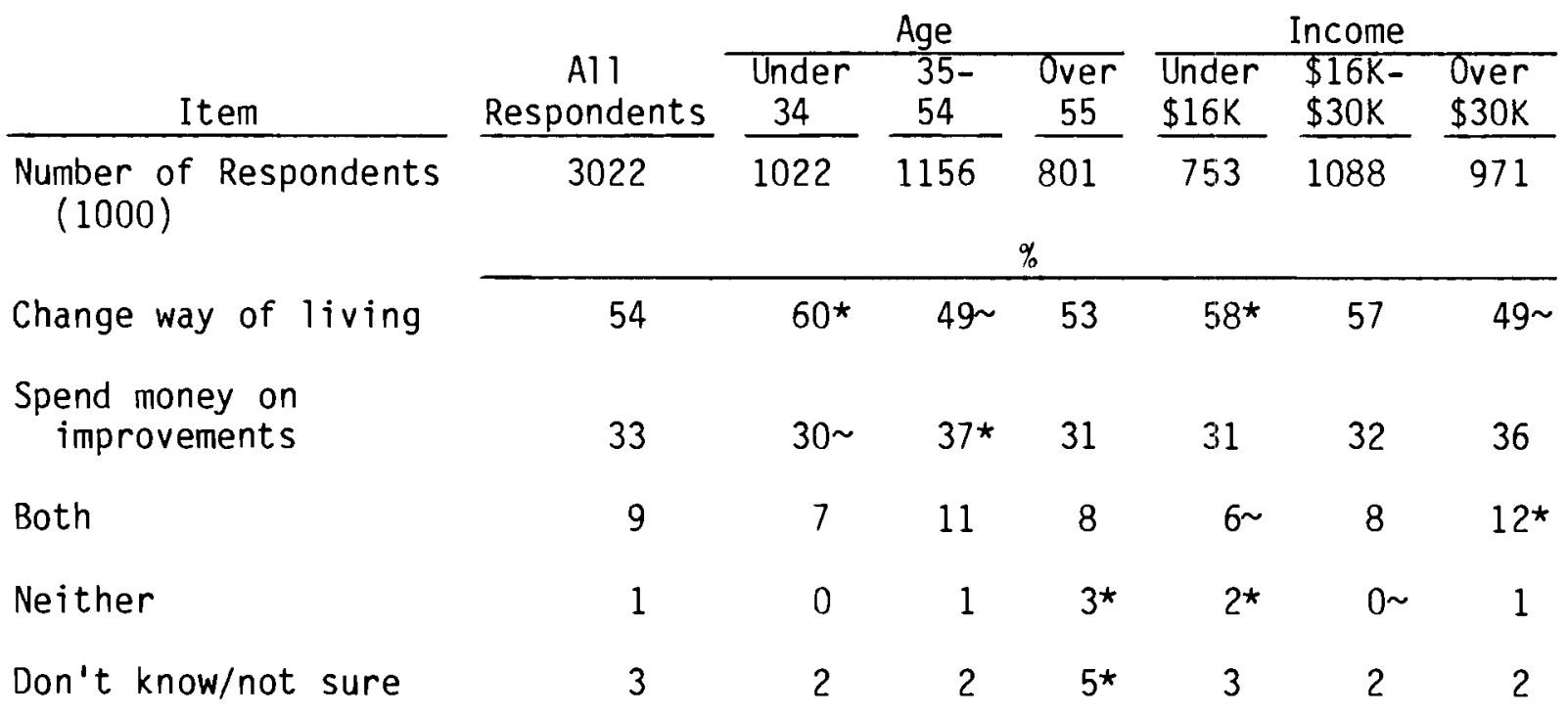


TABLE B.17. Preferred Method of Conserving Energy by Own/Rent, Sex, and Education, 1985

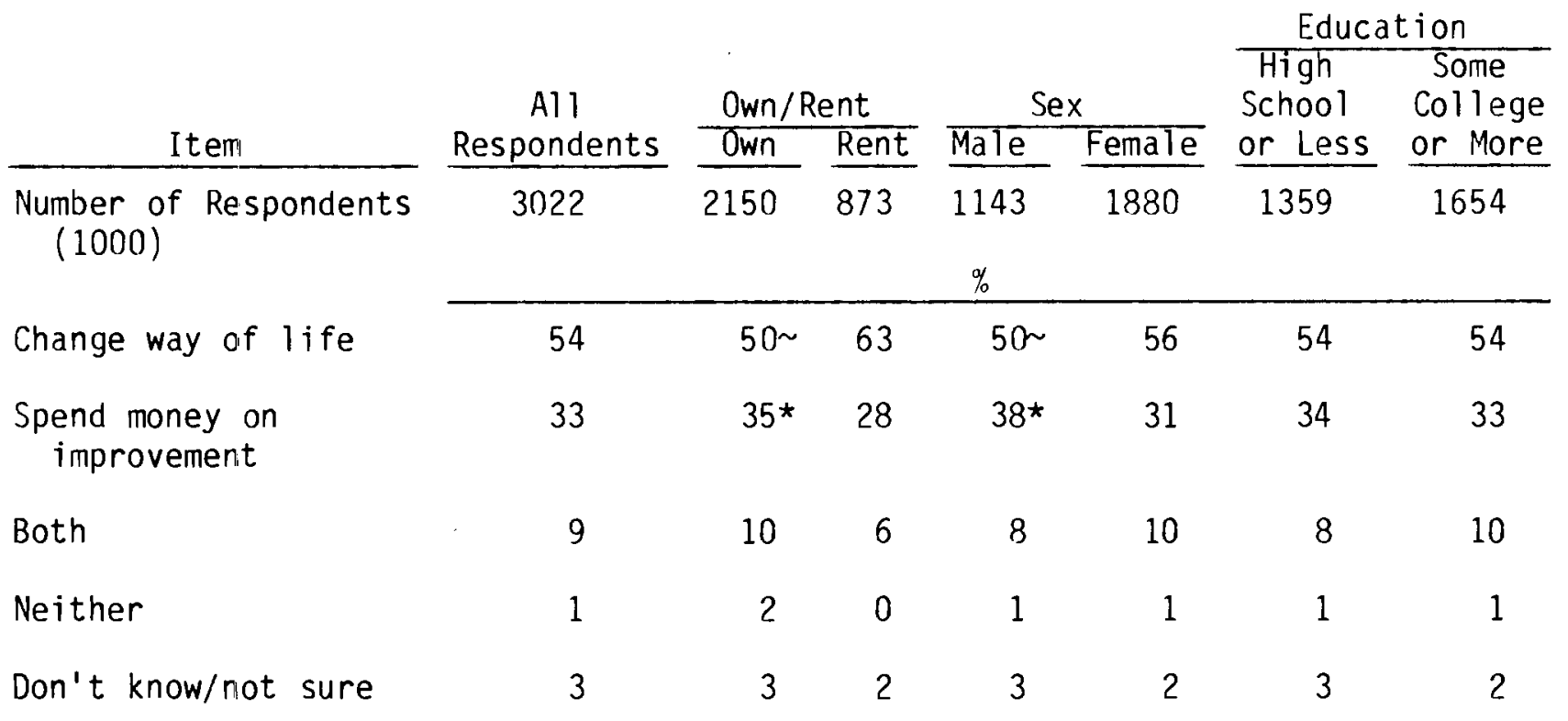

Age, income, and home ownership affected preferences concerning methods for conserving energy; but education and sex did not (Tables B.16 and B.17). Compared to the younger (under 34) group, those in the 35 to 54 year age group were less willing to change their lifestyles. Similarly, those in higher income groups were less willing to change their lifestyles and more likely to prefer to do both. Homeowners and male respondents were less willing to change lifestyle and more likely to prefer spending money on improvements than were renters and female respondents.

Respondents who chose "changing way of living," "spend money on improvements," or "both" were asked further about the first energy conservation measure they would adopt. The most frequently mentioned measures are shown in Table B.18. About one in four respondents would reduce heating temperature. About one in seven would reduce energy consumption. These two top measures were in the "changing ways of living" category. Another frequently mentioned action in this category was to dress warmer (4\%). 
TABLE B.18 The First Measure or Action to be Adopted in Conserving Energy at Home, 1985

\begin{tabular}{lcc} 
Measure/Action & & $\begin{array}{c}\% \text { of All } \\
\text { Respondents }\end{array}$ \\
\cline { 3 - 3 } Changing Way of Living & & \\
Reduce heating temperature & & 33 \\
Reduce energy consumption & & 21 \\
Dress warmer & 4 \\
Spend on Improvements & \\
Insulate & 16 \\
Install solar & 11 \\
Weatherize & 8 \\
Install wood stove & 4
\end{tabular}

About one in six would insulate the house; and about one in ten would install solar or other devices. These were the top measures mentioned in the "spend on improvements" category. Others in this category were to weatherize $(8 \%)$ and to install wood stove $(4 \%)$.

Tables B.19, B.20, and B.21 present the data on the practice of no/lowcost energy conservation measures by home ownership, age, sex, income, education, and average monthly bill. Home ownership, sex, and education appeared to affect the proportions of respondents who practiced no/low-cost conservation actions regularly. Compared to homeowners, renters were more likely to lower their thermostat settings in the heating season or to put plastic over their windows. They were less likely to select energy efficient appliances when purchasing a new one, to control their lights with dimmer switches or timers, or to receive an energy audit. It also appeared that female respondents were more likely than male respondents to use shades and drapes for heating and cooling, to put plastic over their windows, and were less likely to receive an energy audit. People with more education were more likely to wrap their water heaters, to control their lights with dimmer switches or timers, or to have an energy audit. More educated respondents were less likely to put plastic over their windows (Table B.19). 
TABLE B.19. Low Cost Energy Conservation Measures Regularly Used by Own/Rent, Sex, and Education, 1985

\begin{tabular}{|c|c|c|c|c|c|c|c|}
\hline \multirow[b]{2}{*}{ Item } & \multirow[b]{2}{*}{$\begin{array}{c}\text { A11 } \\
\text { Respondents } \\
\end{array}$} & \multirow{2}{*}{\multicolumn{2}{|c|}{ Own/Rent }} & \multirow{2}{*}{\multicolumn{2}{|c|}{ Sex }} & \multicolumn{2}{|c|}{ Education } \\
\hline & & & & & & \multicolumn{2}{|c|}{$\begin{array}{ll}\text { School } & \text { College } \\
\text { Less } & \text { or More }\end{array}$} \\
\hline \multirow{2}{*}{$\begin{array}{l}\text { Number of } \\
\text { Respondents } \\
(1000)\end{array}$} & 3022 & 2150 & 873 & 1143 & 1880 & 1359 & 1654 \\
\hline & \multicolumn{7}{|c|}{$\%$} \\
\hline $\begin{array}{l}\text { Use shade for } \\
\text { heating and } \\
\text { cooling }\end{array}$ & 90 & 89 & 91 & 87 & $91^{*}$ & 88 & 91 \\
\hline $\begin{array}{l}\text { Lower thermostat } \\
\text { setting in the } \\
\text { heating season }\end{array}$ & 85 & 83 & $90 *$ & 84 & 86 & 83 & 87 \\
\hline Wrap water heater & 63 & 65 & 59 & 65 & 62 & 59 & $66^{\star}$ \\
\hline $\begin{array}{l}\text { Select energy- } \\
\text { efficient } \\
\text { appliances } \\
\text { when purchase- } \\
\text { ing a new one }\end{array}$ & 59 & 63 & $50 \sim$ & 60 & 58 & 60 & 58 \\
\hline $\begin{array}{l}\text { Control lights } \\
\text { with dimmer } \\
\text { switch or } \\
\text { timers }\end{array}$ & 44 & 47 & $36 \sim$ & 42 & 45 & 40 & $47 \star$ \\
\hline $\begin{array}{l}\text { Use water flow } \\
\text { restrictors } \\
\text { in showers }\end{array}$ & 36 & 37 & 35 & 37 & 36 & 33 & 38 \\
\hline $\begin{array}{l}\text { Put plastic over } \\
\text { windows }\end{array}$ & 31 & 27 & $39 \star$ & 26 & $33^{\star}$ & 33 & 29 \\
\hline $\begin{array}{l}\text { Receive energy } \\
\text { audit }\end{array}$ & 27 & 32 & $14 \sim$ & $32^{\star}$ & 24 & 21 & 31 * \\
\hline
\end{tabular}

Age and income also affected conservation actions in the following ways. Respondents in the younger (under 34) group were more likely than the older groups to lower thermostat settings during the heating season and to use shades and drapes for heating or cooling, but less likely to select energy efficient 
TABLE B.20. Low Cost Energy Conservation Measures Regularly Used by Age and Income, 1985

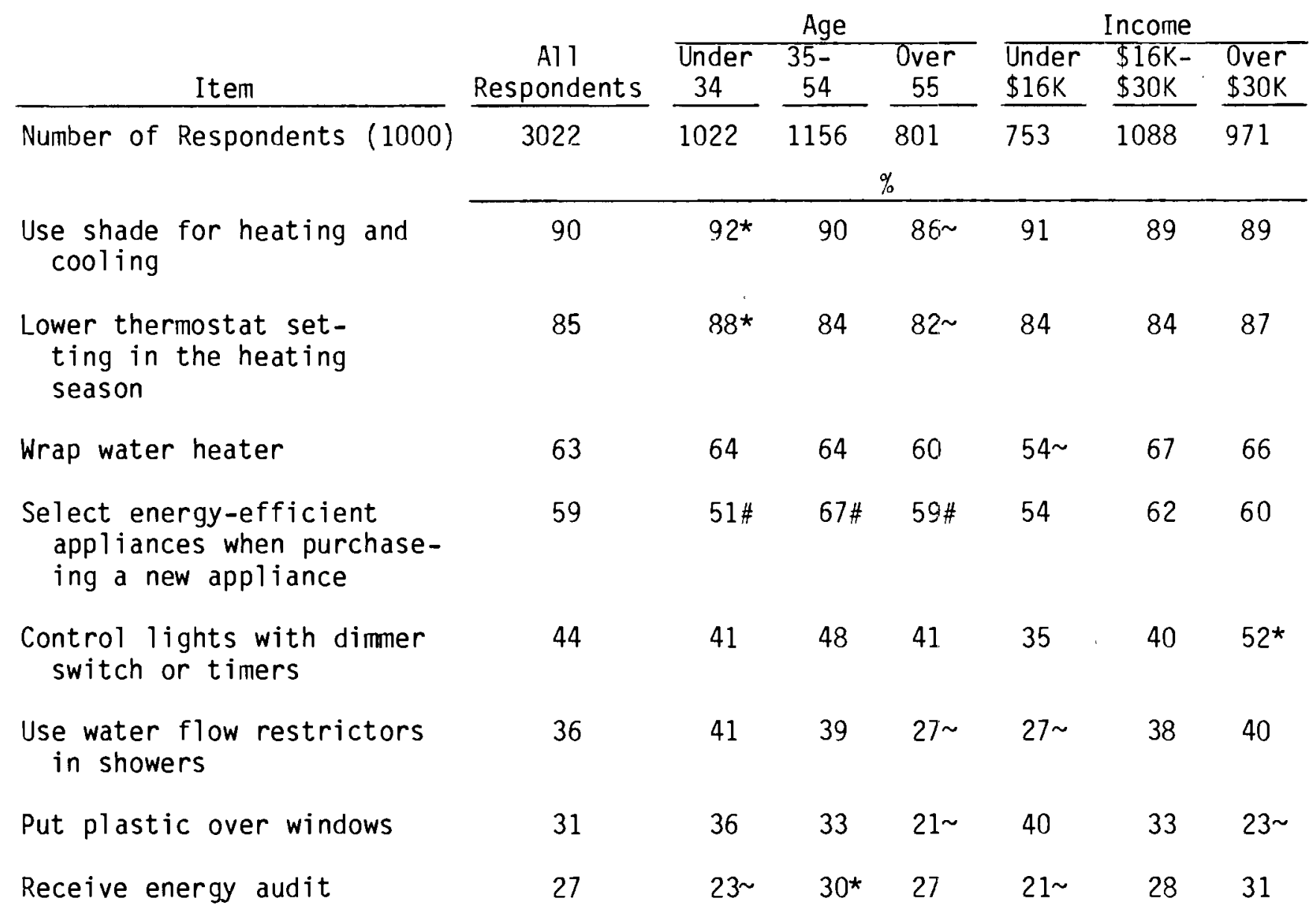

appliances or to have had an energy audit. 0lder respondents (over 55) were less likely than the younger groups to put plastic over their windows or to use water flow restrictors. Lower income respondents were less likely to have wrapped their water heaters, used water flow restrictors, or received an energy audit. In contrast, the higher income (over $\$ 30,000$ ) group appeared to be more likely than the lower income groups to have used dimmer switches or timers to control their lights and less likely to put plastic over windows (Table B.20).

Average monthly utility bills had only limited impact on low-cost energy conservation actions; these bills affected conservation behavior in the following manner. First, respondents whose utility bill was in the mid-range group 
TABLE B.21. Low Cost Energy Conservation Measures Regularly Used by Monthly Utility Bil1, 1985

\begin{tabular}{|c|c|c|c|c|}
\hline Item & $\begin{array}{c}\text { Al1 } \\
\text { Respondents } \\
\end{array}$ & $\begin{array}{c}\text { Month } \\
\text { Under } \\
\$ 50 \\
\end{array}$ & $\begin{array}{l}\text { Uti1i } \\
\$ 51- \\
\$ 75 \\
\end{array}$ & $\begin{array}{c}\text { Bill } \\
\text { Over } \\
\$ 76 \\
\end{array}$ \\
\hline \multirow[t]{2}{*}{ Number of Respondents (1000) } & 2607 & 737 & 934 & 937 \\
\hline & \multicolumn{4}{|c|}{$\%$} \\
\hline Use shade for heating and cooling & 89 & 85 & $94^{\star}$ & 88 \\
\hline $\begin{array}{l}\text { Lower thermostat setting in the } \\
\text { heating season }\end{array}$ & 85 & 83 & 84 & 88 \\
\hline Wrap water heater & 64 & 62 & 65 & 65 \\
\hline $\begin{array}{l}\text { Select energy-efficient appliances } \\
\text { when purchasing a new one }\end{array}$ & 61 & $55^{\sim}$ & 63 & 64 \\
\hline $\begin{array}{l}\text { Control lights with dimmer switch } \\
\text { or timers }\end{array}$ & 44 & 43 & 40 & 48 \\
\hline Use water flow restrictors in showers & 37 & 36 & 37 & 38 \\
\hline Put plastic over windows & 31 & 36 & 32 & 27 \\
\hline Receive energy audit & 28 & $21 \sim$ & 28 & 33 \\
\hline
\end{tabular}

( $\$ 51$ to $\$ 75$ per month on average) were more likely to use shades and drapes for heating and cooling. Secondly, those with the lower energy bills (less than $\$ 50$ per month on average) were less likely to have received an energy audit and to select energy-efficient appliance when purchasing a new one (Table B.21).

Tables B.22, B.23, and B.24 provide the data on investment-type energy conservation measures installed. Age did not impact the proportions of homes equipped with roof or attic insulation, weatherproofing, storm windows, heat pump furnace, heat pump water heater, and solar panel for water heating. However, younger respondents (under 55) were more likely than the over 54 group to have installed a wood stove. Respondents in the middle age (35-54) group were more likely to have installed fireplace inserts or wall insulation. The older (over 54) respondents were more likely to have installed storm doors or clock thermostat controls. In terms of income, the highest income group households 
TABLE B.22. Proportions of Homes Currently Equipped with Specific Energy Conservation Measure by Age and Income, 1985

\begin{tabular}{|c|c|c|c|c|c|c|c|}
\hline & & & Age & & & Income & \\
\hline Item & $\begin{array}{c}\text { Home } \\
\text { Owners } \\
\end{array}$ & $\begin{array}{c}\text { Under } \\
34 \\
\end{array}$ & $\begin{array}{r}35- \\
54 \\
\end{array}$ & $\begin{array}{l}\text { Over } \\
55\end{array}$ & $\begin{array}{l}\text { Under } \\
\$ 16 \mathrm{~K}\end{array}$ & $\begin{array}{l}\$ 16 K- \\
\$ 30 K\end{array}$ & $\begin{array}{l}\text { Over } \\
\$ 30 \mathrm{~K}\end{array}$ \\
\hline Number of Respondents (1000) & 2150 & 526 & 901 & 684 & 451 & 735 & 791 \\
\hline & & & & $\%$ & & & \\
\hline Roof/attic insulation & 91 & 91 & 91 & 91 & $88 \sim$ & 92 & $94 *$ \\
\hline Wall insulation & 80 & $72 \sim$ & $85^{\star}$ & 80 & $75 \sim$ & 79 & $83^{*}$ \\
\hline Weatherproofing & 80 & 82 & 80 & 80 & $74 \sim$ & 81 & $83^{\star}$ \\
\hline Storm/thermal pane windows & 76 & 79 & 74 & 76 & 72 & 79 & 75 \\
\hline Storm or insulated doors & 57 & 47 & 55 & $67 \star$ & 59 & 56 & 57 \\
\hline $\begin{array}{l}\text { Floor, basement or crawl } \\
\text { space insulation }\end{array}$ & 55 & 54 & 58 & 52 & $46 \sim$ & 54 & $61 *$ \\
\hline Clock or setback thermostat & 42 & 35 & 39 & $51 *$ & 43 & 41 & 45 \\
\hline Wood stove/furnace & 39 & $51 *$ & 42 & $26 \sim$ & $32 \sim$ & $45^{\star}$ & 40 \\
\hline Fireplace insert & 20 & 20 & $25 *$ & $14 \sim$ & 14 & 15 & $28 *$ \\
\hline Heat pump furnace & 9 & 6 & 8 & 12 & 6 & 6 & $12^{\star}$ \\
\hline Heat pump water heater & 2 & 5 & 2 & 2 & 3 & 2 & 3 \\
\hline $\begin{array}{l}\text { Solar panels for water } \\
\text { heating }\end{array}$ & 2 & 1 & 3 & 1 & 0 & 0 & 4 \\
\hline
\end{tabular}

were more likely than those of lower income groups to have installed wall and ceiling insulation, weatherproofing, basement or crawl space insulation, fireplace inserts, or a heat pump furnace. The lower income households were less likely to have a wood stove (Table B.22).

Male respondents were more likely to indicate that they have weatherproofed their homes. Respondents with at least some college education were 
TABLE B.23. Proportions of Owner-0ccupied Homes Currently Equipped With Specific Energy Conservation Measure by Sex, Education, and Length of Stay, 1985

\begin{tabular}{|c|c|c|c|c|c|c|c|c|}
\hline \multirow[b]{3}{*}{ Item } & \multirow{3}{*}{$\begin{array}{l}\text { Home } \\
\text { Owners }\end{array}$} & & & \multicolumn{2}{|c|}{ Education } & \multicolumn{3}{|c|}{ Length of Stay } \\
\hline & & \multicolumn{2}{|c|}{ Sex } & \multirow{2}{*}{$\begin{array}{l}\text { High School } \\
\text { or Less } \\
\end{array}$} & \multirow{2}{*}{$\begin{array}{l}\text { Some } \\
\text { College } \\
\text { or More }\end{array}$} & \multirow{2}{*}{$\begin{array}{c}\text { Under } 2 \\
\text { Years } \\
\end{array}$} & \multirow{2}{*}{$\begin{array}{l}3 \text { to } \\
4 \text { Years }\end{array}$} & \multirow{2}{*}{$\begin{array}{l}5 \text { or } \\
\text { More } \\
\text { Years }\end{array}$} \\
\hline & & Male & Female & & & & & \\
\hline & & & & q & & & & \\
\hline Roof/attic insulation & 91 & 94 & 90 & 91 & 92 & $87 \sim$ & $96 *$ & 92 \\
\hline Weatherproofing & 80 & $83^{*}$ & 79 & 79 & 82 & 81 & 85 & 79 \\
\hline Storm/thermal pane windows & 76 & 80 & 74 & 73 & 79 & $83^{\star}$ & 83 & 73 \\
\hline Storm or insulated doors & 57 & 60 & 56 & 58 & 57 & 50 & 60 & $59 *$ \\
\hline Wood stove/furnace & 39 & 41 & 38 & 39 & 39 & 35 & $49 \star$ & 39 \\
\hline Fireplace insert & 20 & 20 & 20 & 21 & 20 & 17 & 15 & 22 \\
\hline Heat pump furnace & 9 & 9 & 9 & 8 & 10 & 9 & 9 & 9 \\
\hline Heat pump water heater & 3 & 1 & 3 & 2 & 2 & 5 & 2 & 2 \\
\hline Solar panels for water heating & 2 & 3 & 1 & 0 & 3 & 2 & 1 & 2 \\
\hline
\end{tabular}


TABLE B.24. Proportions of Homes Currently Equipped with Specific Energy Conservation Measure By Average Monthly Bi11, 1985

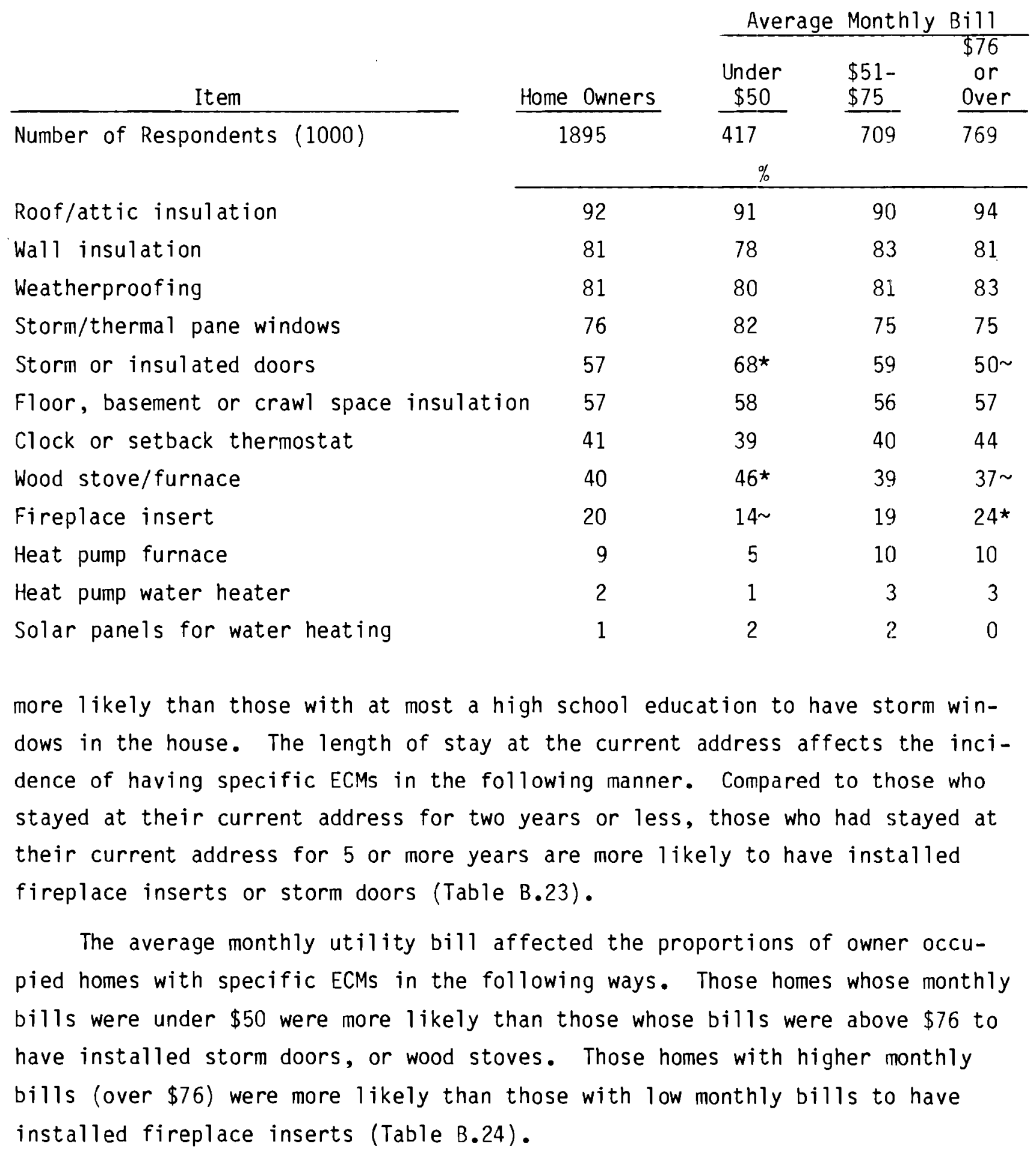


TABLE B.25. Average Amount of Conservation Investment 1983-1985

\begin{tabular}{|c|c|c|}
\hline & $\begin{array}{l}\text { Number of } \\
\text { Homeowners }\end{array}$ & $\begin{array}{l}\text { Average Amount } \\
\text { Invested } \\
\end{array}$ \\
\hline Al1 Homeowners Who Had Invested (1000) & 300 & $\$ 1574$ \\
\hline \multicolumn{3}{|l|}{ Age } \\
\hline Under 34 & 90 & 1472 \\
\hline $35-54$ & 137 & 1825 \\
\hline Over 55 & 70 & 1110 \\
\hline \multicolumn{3}{|l|}{ Sex } \\
\hline Male & 120 & 1390 \\
\hline Female & 180 & 1699 \\
\hline \multicolumn{3}{|l|}{ Income } \\
\hline Under $\$ 16,000$ & 58 & 893 \\
\hline$\$ 16,000$ to 30,000 & 114 & 1510 \\
\hline Over $\$ 30,000$ & 118 & 1877 \\
\hline \multicolumn{3}{|l|}{ Education } \\
\hline Complete High School or Less & 138 & 1330 \\
\hline Some College or More & 162 & 1775 \\
\hline \multicolumn{3}{|l|}{ Monthly Utility Bill } \\
\hline Under $\$ 50$ & 61 & 1900 \\
\hline$\$ 51$ to $\$ 75$ & 104 & 1325 \\
\hline Over $\$ 75$ & 112 & 1379 \\
\hline
\end{tabular}

Table B.25 presents the data on average energy conservation investment for the period 1983-85.

Tables B.26 and B.27 present the data on the sources of financing energy conservation investment by age, sex, income, and education.

Tables B.28, B.29, B.30, and B.31 provide data on the likelihood of installing specific ECMs in the next two or three years by age, sex, income, education, current and expected future stay in the current address, and average monthly utility bill.

\section{B.5 SUPPORTING DATA FOR CHAPTER 6.0}

Tables B.32 through B.45 present supporting data for the analyses in Chapter 6.0. Except for Tables B.32, B.33, and B.34, all the tables show the 
TABLE B.26. Financing Sources for Energy Conservation Investment by Age and Sex, 1985

\begin{tabular}{|c|c|c|c|c|c|c|}
\hline \multirow[b]{3}{*}{ Item } & \multirow[b]{3}{*}{ Homeowners } & \multicolumn{3}{|c|}{ Age } & \multirow{2}{*}{\multicolumn{2}{|c|}{ Sex }} \\
\hline & & \multirow{2}{*}{$\begin{array}{c}\text { Under } \\
34 \\
\end{array}$} & \multirow{2}{*}{$\begin{array}{l}35- \\
54 \\
\end{array}$} & \multirow{2}{*}{$\begin{array}{c}\text { Over } \\
54 \\
\end{array}$} & & \\
\hline & & & & & Male & Female \\
\hline Number of Homeowners $(1000)$ & 1752 & 411 & 757 & 554 & 638 & 1115 \\
\hline & & & $\%$ & & & \\
\hline Current income & 63 & 63 & 62 & 64 & 62 & 63 \\
\hline Savings & 19 & $14 \sim$ & 18 & $24^{*}$ & 18 & 20 \\
\hline Delay/cut back purchases & 2 & 2 & 1 & 1 & 1 & 2 \\
\hline Bank loans and credit & 8 & $12^{\star}$ & 9 & $5 \sim$ & 10 & 2 \\
\hline Utility loan & 2 & 2 & 2 & 2 & 3 & 2 \\
\hline Payments by utility & 3 & 4 & 4 & 3 & 4 & 3 \\
\hline Paid by others & 1 & 1 & 1 & 0 & 1 & 0 \\
\hline Federal tax credits & 1 & 1 & 1 & 0 & 0 & 1 \\
\hline Combined sources & 2 & 2 & 2 & 1 & 1 & 2 \\
\hline Other & 0 & 1 & 0 & 0 & 0 & 0 \\
\hline
\end{tabular}

results of the separate tests for 1983 and 1985. There is a corresponding table in the text of Chapter 6.0 showing the results of comparing the 1985 data with 1983 data. The discussion of the information contained in the tables included in this part of Appendix $B$ has been incorporated in Chapter 6.0 .

Tables B.32 and B.33 show the composition of the market segments and derivation of prospect groups for 1985 and 1983 respectively. They are the underlying data for Table 6.1

Tables B.34 and B.35 provide comparisons of demographic and other characteristics of prospect groups between 1983 and 1985, and the results of separate tests for 1983 and 1985.

Tables B. 36 and B. 37 show the results of the test for, respectively, consumers concern about various issues by prospect group, and psychographic profiles by prospect group. 
TABLE B.27. Financing Sources for Energy Conservation Investment by Income and Education, 1985

\begin{tabular}{|c|c|c|c|c|c|c|}
\hline \multirow[b]{2}{*}{ Item } & \multirow[b]{2}{*}{ Homeowners } & & \multicolumn{2}{|c|}{ Education } \\
\hline & & $\begin{array}{l}\text { Under } \\
\$ 16 \mathrm{~K}\end{array}$ & $\begin{array}{l}\text { Income } \\
\$ 16 \mathrm{~K} \\
\$ 30 \mathrm{~K}\end{array}$ & $\begin{array}{l}\text { Over } \\
\$ 30 \mathrm{~K}\end{array}$ & $\begin{array}{l}\text { High } \\
\text { School } \\
\text { or Less }\end{array}$ & $\begin{array}{l}\text { Some } \\
\text { College } \\
\text { or More }\end{array}$ \\
\hline \multirow[t]{2}{*}{ Number of Horneowners (1000) } & 1752 & 363 & 591 & 668 & 816 & 930 \\
\hline & \multicolumn{6}{|c|}{$\%$} \\
\hline Current income & 63 & 66 & 57 & 66 & $67 *$ & 59 \\
\hline Savings & 19 & 18 & 23 & 16 & 17 & 21 \\
\hline Delay/cut back purchases & 2 & 3 & 1 & 1 & 2 & 1 \\
\hline Bank loans and credit & 8 & $4 \sim$ & 10 & 10 * & $5 \sim$ & 11 \\
\hline Utility loan & 2 & 1 & 3 & 2 & 2 & 3 \\
\hline Payments by utility & 3 & 4 & 2 & 4 & 4 & 3 \\
\hline Paid by others & 1 & 1 & 1 & 0 & 1 & 1 \\
\hline Federal tax credits & 1 & 1 & 0 & 0 & 1 & 0 \\
\hline Combined services & 2 & 2 & 1 & 1 & 2 & 2 \\
\hline Other & 0 & 0 & 0 & 0 & 0 & 0 \\
\hline
\end{tabular}

Tables B.38, B.39, and B.40 show the results of the test on consumers' perceptions of institutions by prospect group. Table B.38 covers the overall impression of energy institutions. Table B.39 covers the believability of energy institutions as sources of energy conservation information. Similarly, Table B.40 covers the believability of other entities and individuals as sources of energy conservation information.

Tables B.41 through B.45 present the results for separate tests for 1983 and 1985 on data relating energy conservation practices, investment, and financing. Table B.41 covers the results on the preferred method for conserving energy at the home. Table B.42 covers no/low cost energy conservation actions. Table B.43 covers investment-type ECMs. Table B.44 covers sources of financing. Table B.45 covers likely future installation of ECMs. 
TABLE B.28. Likelihood of Installing Specific Energy Conservation Measures During the Next Two to Three Years by Age and Sex, 1985

\begin{tabular}{|c|c|c|c|c|c|c|}
\hline \multirow[b]{3}{*}{ Item } & \multirow[b]{3}{*}{ Homeowners } & \multicolumn{3}{|c|}{ Age } & \multirow{2}{*}{\multicolumn{2}{|c|}{ Sex }} \\
\hline & & \multirow{3}{*}{$\begin{array}{l}\text { Under } \\
34 \\
526\end{array}$} & \multirow{3}{*}{$\begin{array}{l}35- \\
54 \\
901\end{array}$} & \multirow{3}{*}{$\begin{array}{l}\text { Over } \\
55 \\
684\end{array}$} & & \\
\hline & & & & & Male & Female \\
\hline \multirow[t]{2}{*}{ Number of Respondents (1000) } & 2150 & & & & 792 & 1358 \\
\hline & $\%$ Very & Likely & or $\mathrm{S}$ & newhat & Likel & \\
\hline Weatherproofing & 41 & $64 \#$ & $41 \#$ & $22 \#$ & 41 & 41 \\
\hline Roof/attic insulation & 21 & 26 & 25 & $10 \sim$ & 23 & 19 \\
\hline $\begin{array}{l}\text { Floor, basement/crawl space } \\
\text { insulation }\end{array}$ & 16 & 25 & 18 & $6 \sim$ & 16 & 16 \\
\hline Storm or insulated doors & 15 & $26 \#$ & $17 \#$ & 4\# & $11 \sim$ & 17 \\
\hline Wall insulation & 11 & $21 \#$ & $10 \#$ & $5 \#$ & 10 & 12 \\
\hline Solar panel for water heating & 9 & 15 & 10 & $3 \sim$ & 13 & $7 \sim$ \\
\hline Wood stove/furnace & 9 & $17 \#$ & $10 \#$ & $2 \#$ & 9 & 10 \\
\hline Fireplace insert & 9 & 10 & 13 & $3 \sim$ & 7 & 10 \\
\hline Storm/thermal pane windows & 9 & 10 & 12 & $3 \sim$ & 7 & 9 \\
\hline Heat pump furnace & 7 & 10 & 9 & $3 \sim$ & 9 & 6 \\
\hline Clock or setback thermostat & 7 & 12 & 8 & $3 \sim$ & 10 & $6 \sim$ \\
\hline Heat pump water heater & 6 & 9 & 7 & $1 \sim$ & 6 & 6 \\
\hline
\end{tabular}


TABLE B.29. Likelihood of Installing Specific Energy Conservation Measures During the Next Two to Three Years by Income and Education, 1985

\begin{tabular}{|c|c|c|c|c|c|c|}
\hline \multirow[b]{2}{*}{ Item } & \multirow[b]{2}{*}{ Homeowners } & & \multicolumn{2}{|c|}{ Education } \\
\hline & & $\begin{array}{l}\text { Under } \\
\$ 16 K \\
\end{array}$ & $\begin{array}{l}\text { Income } \\
\$ 16 \mathrm{~K} \\
\$ 30 \mathrm{~K} \\
\end{array}$ & $\begin{array}{l}\text { Over } \\
\$ 30 \mathrm{~K} \\
\end{array}$ & $\begin{array}{l}\text { High } \\
\text { School } \\
\text { or Less } \\
\end{array}$ & $\begin{array}{l}\text { Some } \\
\text { College } \\
\text { or More } \\
\end{array}$ \\
\hline Number of Respondents & 2150 & 451 & 735 & 791 & 1001 & 1139 \\
\hline & $\%$ & ery Lik & ely or & Somewhat & Likely & \\
\hline Weatherproofing & 41 & $31 \sim$ & 49 & 42 & 41 & 41 \\
\hline Roof/attic insulation & 21 & 16 & 24 & 21 & 22 & 19 \\
\hline $\begin{array}{l}\text { Floor, basement/crawlspace } \\
\text { insulation }\end{array}$ & 16 & 13 & 19 & 17 & 17 & 15 \\
\hline Storm or insulated doors & 15 & 8 & $22^{\star}$ & 13 & 14 & 16 \\
\hline Wall insulation & 11 & 11 & 14 & 9 & 13 & 10 \\
\hline $\begin{array}{c}\text { Solar panel for water } \\
\text { heating }\end{array}$ & 9 & $4 \sim$ & 10 & 12 & 5 & $13^{\star}$ \\
\hline Wood stove/furnace & 9 & $3 \sim$ & 13 & 9 & 8 & 10 \\
\hline Fireplace insert & 9 & $3 \sim$ & 13 & 10 & 9 & 9 \\
\hline Storm/thermal pane windows & 9 & 6 & 9 & 11 & 12 & $6 \sim$ \\
\hline Heat pump furnace & 7 & 5 & 5 & $11^{\star}$ & 6 & 8 \\
\hline Clock or setback thermostat & 7 & 4 & 9 & 9 & 5 & $9 *$ \\
\hline Heat pump water heater & 6 & 4 & 7 & 6 & 7 & 5 \\
\hline
\end{tabular}


TABLE B.30. Likelihood of Installing Specific Energy Conservation Measures During the Next Two to Three Years By Current and Expected Length of Stay, 1985

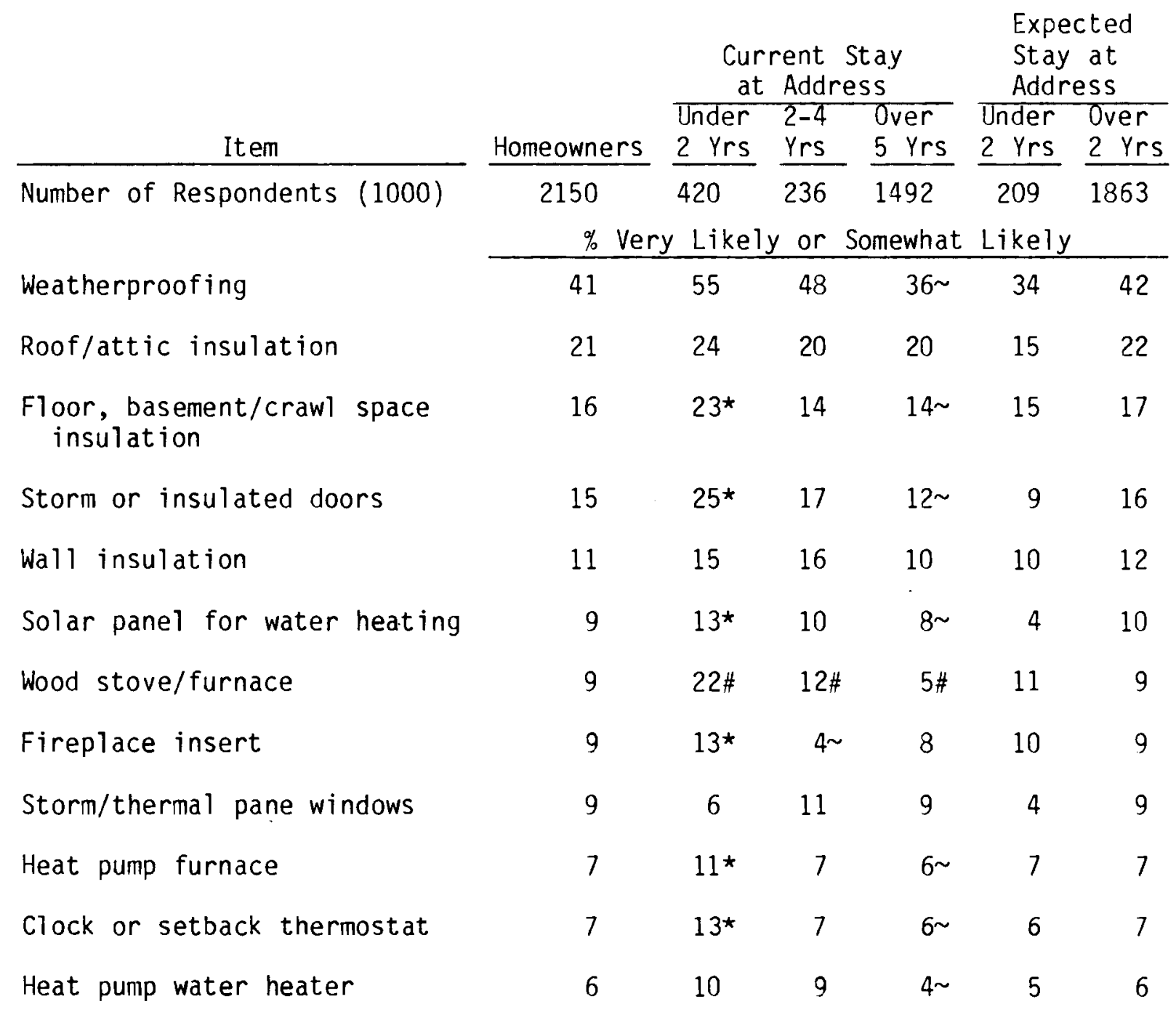


TABLE B.31. Likelihood of Installing Specific Energy Conservation Measures During the Next Two to Three Years by Monthly Energy Bill, 1985

\begin{tabular}{|c|c|c|c|c|}
\hline \multirow[b]{2}{*}{ Item } & \multirow{3}{*}{$\frac{\text { Homeowners }}{2150}$} & \multicolumn{3}{|c|}{ Monthly Bill } \\
\hline & & $\begin{array}{c}\text { Under } \\
\$ 50\end{array}$ & $\begin{array}{r}\$ 51- \\
\$ 75\end{array}$ & $\begin{array}{r}\text { Over } \\
\$ 76\end{array}$ \\
\hline \multirow[t]{2}{*}{ Number of Respondents (1000) } & & 417 & 709 & 769 \\
\hline & \multicolumn{2}{|c|}{$\%$ Very Likely or } & \multicolumn{2}{|c|}{ Somewhat Likely } \\
\hline Weatherproofing & 41 & $32 \sim$ & 44 & 45 \\
\hline Roof/attic insulation & 21 & $12^{\sim}$ & 21 & 24 \\
\hline Floor basement/crawl space insulation & 16 & $11 \sim$ & 15 & $19 *$ \\
\hline Storm or insulated doors & 15 & $10^{\sim}$ & 16 & $17^{\star}$ \\
\hline Wall insulation & 11 & $8 \sim$ & 10 & $14^{*}$ \\
\hline Solar panel for water heating & 9 & 11 & 8 & 9 \\
\hline Wood stove/furnace & 9 & 6 & 7 & $14^{*}$ \\
\hline Fireplace insert & 9 & 5 & 6 & $13^{*}$ \\
\hline Storm/thermal pane windows & 9 & $4 \sim$ & 8 & $12^{*}$ \\
\hline Heat pump furnace & 7 & $2 \sim$ & 7 & $10^{*}$ \\
\hline Clock or setback thermostat & 7 & 5 & 5 & $10^{*}$ \\
\hline Heat pump water heater & 6 & 7 & $3 \sim$ & 9 \\
\hline
\end{tabular}


TABLE B.32. Residential Energy Conservation Market Segments and Prospect Groups, 1985

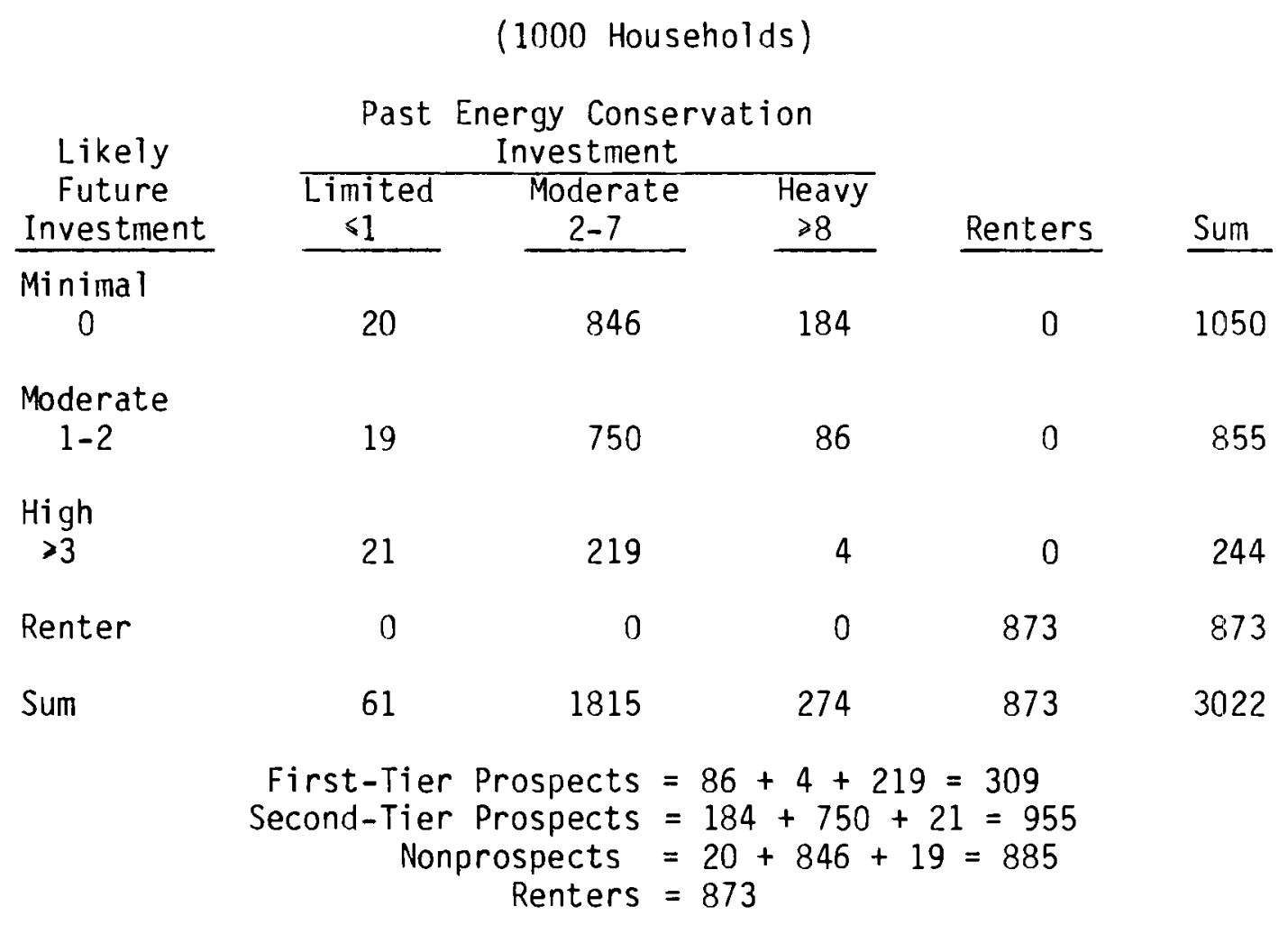


TABLE B.33. Residential Energy Conservation Market Segments and Prospect Groups, 1983

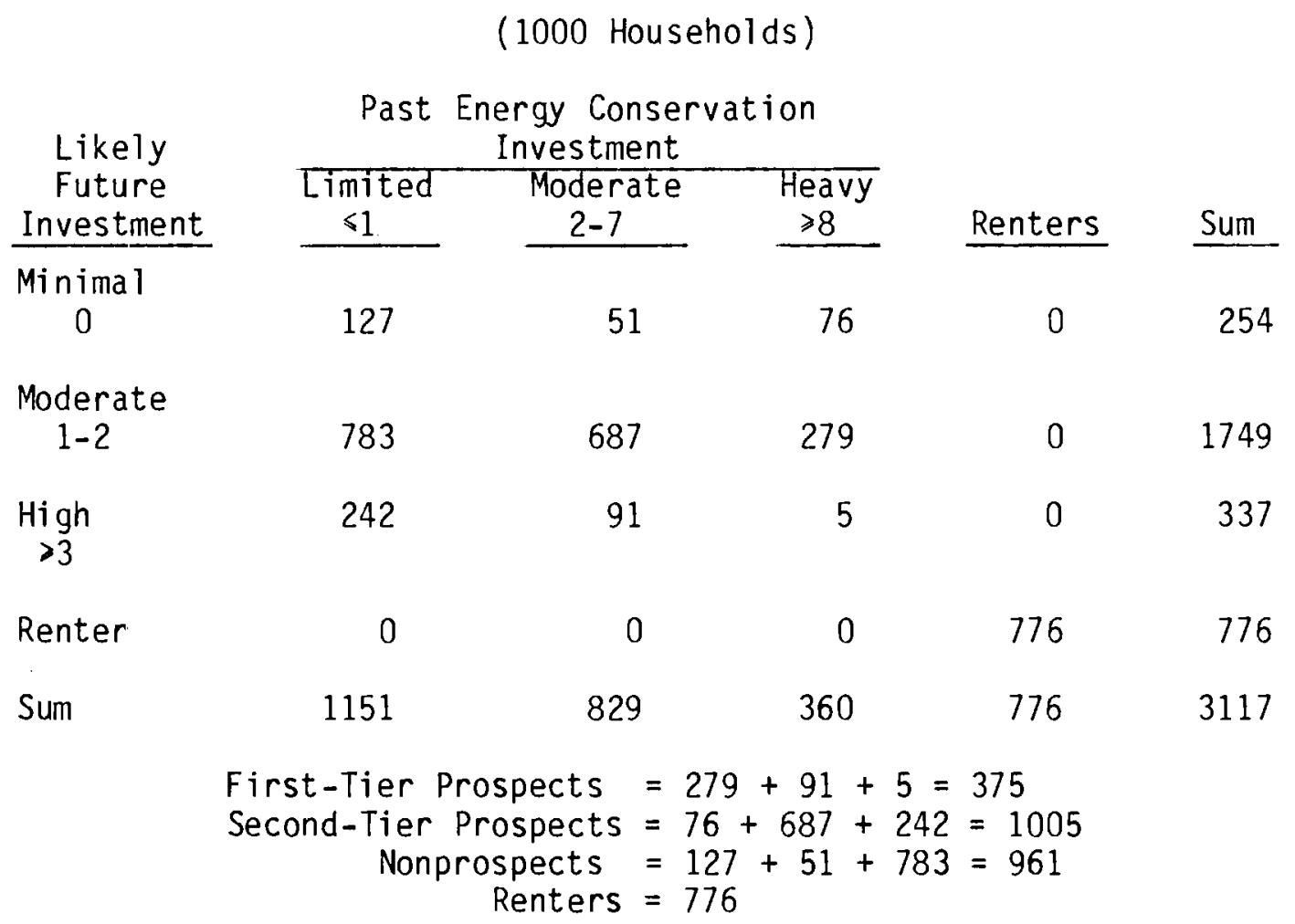


TABLE B.34. Demographics and Other Characteristics of Prospect Groups, 1985 versus 1983

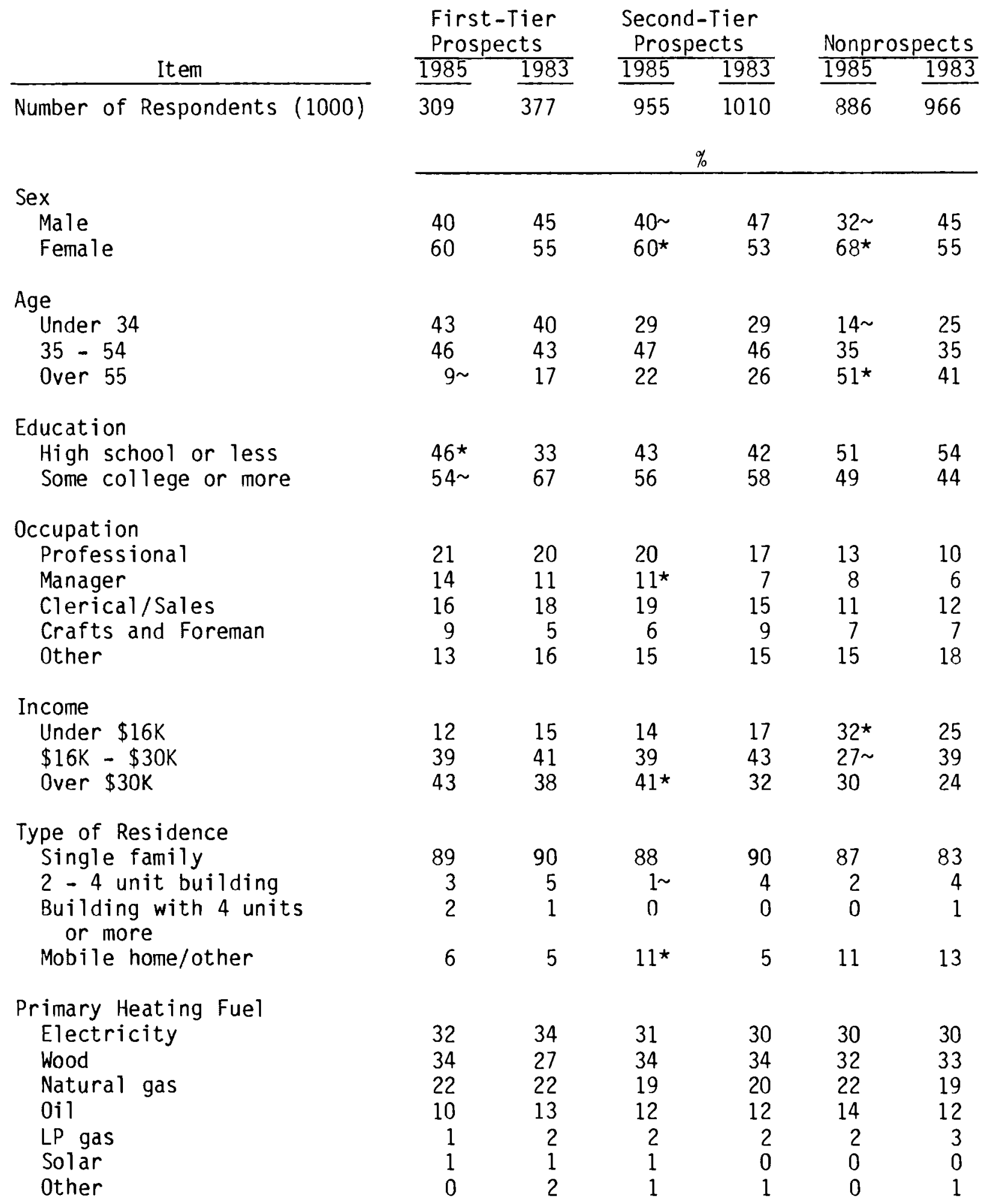


TABLE B.35. Demographics and Fuel Use Characteristics of Prospect Groups, Separate Tests for 1985 and 1983 Results

\begin{tabular}{|c|c|c|c|c|c|}
\hline \multicolumn{2}{|r|}{ It em } & \multirow{2}{*}{$\begin{array}{l}\text { Base } \\
3022 \\
3117\end{array}$} & \multirow{2}{*}{$\begin{array}{c}\text { First-Tier } \\
\text { Prospects } \\
\\
309 \\
377\end{array}$} & \multirow{2}{*}{$\begin{array}{c}\text { Second-Tier } \\
\text { Prospects } \\
\\
955 \\
1010 \\
\%\end{array}$} & \multirow{2}{*}{$\begin{array}{c}\text { Nonprospects } \\
\\
886 \\
966\end{array}$} \\
\hline $\begin{array}{r}\text { Number } \\
1985 \\
1983\end{array}$ & of Respondents (1000) & & & & \\
\hline $\begin{array}{l}\text { Proport } \\
1985 \\
1983\end{array}$ & ion of Total Sample & $\begin{array}{l}100 \\
100\end{array}$ & $\begin{array}{l}10 \\
12\end{array}$ & $\begin{array}{l}32 \\
32\end{array}$ & $\begin{array}{l}29 \\
31\end{array}$ \\
\hline $\begin{array}{r}\text { Gender } \\
1985\end{array}$ & $\begin{array}{l}\text { Male } \\
\text { Female }\end{array}$ & $\begin{array}{l}37 \\
63\end{array}$ & $\begin{array}{l}40 \\
60\end{array}$ & $\begin{array}{l}40^{\star} \\
60^{2}\end{array}$ & $\begin{array}{l}32 \sim \\
68^{\star}\end{array}$ \\
\hline 1983 & $\begin{array}{l}\text { Male } \\
\text { Female }\end{array}$ & $\begin{array}{l}46 \\
54\end{array}$ & $\begin{array}{l}45 \\
55\end{array}$ & $\begin{array}{l}47 \\
53\end{array}$ & $\begin{array}{l}45 \\
55\end{array}$ \\
\hline $\begin{array}{l}\text { Age } \\
1985\end{array}$ & $\begin{array}{l}\text { Under } 34 \\
35-54 \\
\text { Over } 55\end{array}$ & $\begin{array}{l}25 \\
42 \\
26\end{array}$ & $\begin{array}{l}43 \# \\
46 \\
9 \#\end{array}$ & $\begin{array}{l}29 \# \\
47 \\
22 \#\end{array}$ & $\begin{array}{l}14 \# \\
35 \sim \\
41 \#\end{array}$ \\
\hline 1983 & $\begin{array}{l}\text { Under } 34 \\
35-54 \\
\text { Over } 55\end{array}$ & $\begin{array}{l}38 \\
36 \\
26\end{array}$ & $\begin{array}{l}40^{\star} \\
43 \\
17 \#\end{array}$ & $\begin{array}{l}29 \\
46 \\
26 \#\end{array}$ & $\begin{array}{l}25 \\
35 \sim \\
41 \#\end{array}$ \\
\hline $\begin{array}{l}\text { Educati } \\
1985\end{array}$ & $\begin{array}{l}\text { on } \\
\text { High school or less } \\
\text { Some college or more }\end{array}$ & $\begin{array}{l}47 \\
53\end{array}$ & $\begin{array}{l}46 \\
54\end{array}$ & $\begin{array}{l}43^{\sim} \\
56^{\star}\end{array}$ & $\begin{array}{l}51^{*} \\
49 \sim\end{array}$ \\
\hline 1983 & $\begin{array}{l}\text { High school or less } \\
\text { Some college or more }\end{array}$ & $\begin{array}{l}44 \\
54\end{array}$ & $\begin{array}{l}33 \# \\
67 \#\end{array}$ & $\begin{array}{l}42 \# \\
58 \#\end{array}$ & $\begin{array}{l}54 \# \\
44 \#\end{array}$ \\
\hline $\begin{array}{r}\text { Income } \\
1985\end{array}$ & $\begin{array}{l}\text { Under } \$ 16 \mathrm{~K} \\
\$ 16 \mathrm{~K}-\$ 30 \mathrm{~K} \\
\text { Over } \$ 30 \mathrm{~K}\end{array}$ & $\begin{array}{l}21 \\
34 \\
37\end{array}$ & $\begin{array}{l}12 \\
39 \\
43\end{array}$ & $\begin{array}{l}14 \\
39 \\
41\end{array}$ & $\begin{array}{l}32^{\star} \\
27 \sim \\
30^{\sim}\end{array}$ \\
\hline 1983 & $\begin{array}{l}\text { Under } \$ 16 \mathrm{~K} \\
\$ 16 \mathrm{~K}-\$ 30 \mathrm{~K} \\
\text { Over } \$ 30 \mathrm{~K}\end{array}$ & $\begin{array}{l}25 \\
40 \\
27\end{array}$ & $\begin{array}{l}15 \\
41 \\
38\end{array}$ & $\begin{array}{l}17 \\
43 \\
32\end{array}$ & $\begin{array}{l}25^{\star} \\
39 \\
24 \sim\end{array}$ \\
\hline
\end{tabular}


TABLE B.35. (contd)

\begin{tabular}{|c|c|c|c|c|c|}
\hline & Item & Base & $\begin{array}{l}\text { First-Tier } \\
\text { Prospects }\end{array}$ & $\begin{array}{l}\text { Second-Tier } \\
\text { Prospects } \\
\end{array}$ & Nonprospects \\
\hline Occupat & ion & & & & \\
\hline 1985 & Professional & 17 & 21 & 20 & $13 \sim$ \\
\hline & Manager & 10 & 14 & 11. & 3 \\
\hline & Clerical/Sales & 15 & 16 & $19 *$ & 11 \\
\hline & Crafts and Foreman & 7 & 9 & 6 & 7 \\
\hline & Other & 14 & 13 & 15 & 15 \\
\hline 1983 & Professional & 16 & 20 & 17 & $10^{\sim}$ \\
\hline & Manager & 6 & $11 *$ & 7 & 6 \\
\hline & Clerical/Sales & 14 & $18^{\star}$ & 15 & $12 \sim$ \\
\hline & Crafts and Foreman & 8 & 5 & 9 & 7 \\
\hline & Other & 16 & 16 & 15 & 18 \\
\hline Type of & Residence & & & & \\
\hline 1985 & Single family & 88 & 89 & 88 & 87 \\
\hline & 2-4 unit building & 2 & 3 & 1 & 2 \\
\hline & $\begin{array}{l}\text { Building with } 4 \text { or } \\
\text { more units }\end{array}$ & 1 & 2 & 0 & 0 \\
\hline & Mobile home/other & 10 & 6 & 11 & 11 \\
\hline 1983 & Single family & 76 & 90 & 90 & $83^{\sim}$ \\
\hline & 2-4 unit building & 8 & 5 & 4 & 4 \\
\hline & $\begin{array}{l}\text { Building with } 4 \text { or } \\
\text { more units }\end{array}$ & 8 & 1 & 0 & 1 \\
\hline & Mobile home/other & 8 & 5 & 5 & $13^{\star}$ \\
\hline Primary & Heating Fuel & & & & \\
\hline 1985 & Electricity & 31 & 32 & 31 & 30 \\
\hline & Wood & 33 & 34 & 34 & 32 \\
\hline & Natural gas & 21 & 22 & 19 & 22 \\
\hline & $0 \mathrm{il}$ & 12 & 10 & 12 & 14 \\
\hline & LP gas & 2 & 1 & 2 & 2 \\
\hline & Solar & 0 & 1 & 1 & 0 \\
\hline & other & 1 & 0 & l & 0 \\
\hline 1983 & Electricity & 37 & 34 & 30 & 30 \\
\hline & Wood & 28 & 27 & 34 & 33 \\
\hline & Natural gas & 20 & 22 & 20 & 19 \\
\hline & 0 il & 11 & 13 & 12 & 12 \\
\hline & LP gas & 3 & 2 & 2 & 3 \\
\hline & Solar & 0 & 1 & 0 & 0 \\
\hline & Other & 1 & 1 & 1 & 1 \\
\hline
\end{tabular}


TABLE B.36. Concern About Various Issues By Prospect Group, Separate Tests for 1985 and 1983

\begin{tabular}{|c|c|c|c|c|}
\hline Item & Base & $\begin{array}{l}\text { First-Tier } \\
\text { Prospects } \\
\end{array}$ & $\begin{array}{l}\text { Second-Tier } \\
\text { Prospects }\end{array}$ & Nonprospects \\
\hline $\begin{array}{l}\text { Number of Respondents (1000) } \\
1985 \\
1983\end{array}$ & $\begin{array}{l}3022 \\
3117\end{array}$ & $\begin{array}{l}309 \\
377\end{array}$ & $\begin{array}{r}955 \\
1010 \\
\\
\text { lery Concerned } \\
\end{array}$ & $\begin{array}{l}886 \\
966\end{array}$ \\
\hline $\begin{array}{l}\text { Energy Conservation } \\
1985 \\
1983\end{array}$ & $\begin{array}{l}31 \\
49\end{array}$ & $\begin{array}{l}34 \\
57 *\end{array}$ & $\begin{array}{l}33 \\
48\end{array}$ & $\begin{array}{l}28 \\
49 \sim\end{array}$ \\
\hline $\begin{array}{l}\text { Unemployment } \\
\quad 1985 \\
1983\end{array}$ & $\begin{array}{l}46 \\
63\end{array}$ & $\begin{array}{l}50 \\
61\end{array}$ & $\begin{array}{l}43 \\
63\end{array}$ & $\begin{array}{l}44 \\
64\end{array}$ \\
\hline $\begin{array}{c}\text { Cost of Energy } \\
1985 \\
1983\end{array}$ & $\begin{array}{l}50 \\
73\end{array}$ & $\begin{array}{l}51 \\
74\end{array}$ & $\begin{array}{l}51 \\
70\end{array}$ & $\begin{array}{l}48 \\
75\end{array}$ \\
\hline $\begin{array}{l}\text { Inflation } \\
\quad 1985 \\
1983\end{array}$ & $\begin{array}{l}54 \\
65\end{array}$ & $\begin{array}{l}51 \\
74\end{array}$ & $\begin{array}{l}52 \\
63\end{array}$ & $\begin{array}{l}56 \\
65\end{array}$ \\
\hline $\begin{array}{l}\text { Crime } \\
1985 \\
1983\end{array}$ & $\begin{array}{l}68 \\
74\end{array}$ & $\begin{array}{l}60 \sim \\
73\end{array}$ & $\begin{array}{l}67 \\
72\end{array}$ & $\begin{array}{l}72^{\star} \\
75\end{array}$ \\
\hline $\begin{array}{l}\text { Energy Use in the Home } \\
1985 \\
1983\end{array}$ & $\begin{array}{l}33 \\
53\end{array}$ & $\begin{array}{l}44^{*} \\
53\end{array}$ & $\begin{array}{l}30 \\
49\end{array}$ & $\begin{array}{l}33 \\
50\end{array}$ \\
\hline $\begin{array}{l}\text { Environment } \\
\begin{array}{l}1985 \\
1983\end{array}\end{array}$ & $\begin{array}{l}48 \\
53\end{array}$ & $\begin{array}{l}57^{\star} \\
66^{\star}\end{array}$ & $\begin{array}{l}48 \\
49\end{array}$ & $\begin{array}{l}44 \sim \\
52\end{array}$ \\
\hline
\end{tabular}


TABLE B.37. Psychographical Profiles by Prospect Group, Separate Tests for 1985 and 1983 a

\begin{tabular}{|c|c|c|c|c|c|}
\hline \multicolumn{2}{|r|}{ It em } & Base & $\begin{array}{l}\text { First-Tier } \\
\text { Prospects } \\
\end{array}$ & $\begin{array}{l}\text { Second-Tier } \\
\text { Prospects }\end{array}$ & Nonprospects \\
\hline $\begin{array}{c}\text { Number of } \\
1985 \\
1983\end{array}$ & Respondents (1000) & $\begin{array}{l}3022 \\
3117\end{array}$ & $\begin{array}{l}309 \\
377\end{array}$ & $\begin{array}{r}955 \\
1010\end{array}$ & $\begin{array}{l}886 \\
966\end{array}$ \\
\hline & & & $\%$ Stron & 1 y Agree or & gree \\
\hline
\end{tabular}

Social Responsibility:

It's our responsibility to conserve electricity for future generations.

1985

1983

$84 \quad 88$

$76 \quad 81$

83

79

84

79

72

Conserving energy is the best

way to protect the environment. 1985

1983

$71 \quad 71$

71

72

$50 \quad 56$

53

46

Self Interest/Materialism/

Lifestyle:

Most people who conserve energy

do so to save money. 1985

1983

92

82

90

92

93

would only make conservation investments which would enhance the value of my home. 1985

1983

23

23

25

21

25

Conserving energy is the best way to maintaining my lifestyle. 1985

1983

$63 \quad 68$

46

62

63

46

47

44 
TABLE B.37. (contd)

\begin{tabular}{|c|c|c|c|c|}
\hline Item & Base & $\begin{array}{l}\text { First-Tier } \\
\text { Prospects }\end{array}$ & $\begin{array}{l}\text { Second-Tier } \\
\text { Prospects }\end{array}$ & Nonprospects \\
\hline
\end{tabular}

Limits to Energy Conservation:

I only use electricity when it's really needed; there is no way I can cut down. 1985

1983

$47 \quad 42$

$50 \quad 41$

44

51

I have already done everything

I can to conserve energy. 1985

1983

$38 \quad 23 \#$

$34 \#$

48\#

$39 \quad 25 \# \quad 36 \# \quad 47 \#$

Cynicism/Negative Views on Energy Conservation:

The amount of energy I use is really my own affair and no one else's. 1985 1983

It's silly to conserve electricity, because the electric utility just turn around and charge more for what you do use. 1985 1983

My conservation efforts won't have much effect one way or the other on the availability of electricity. 1985 1983

$22 \quad 14$

20

27

(a) The 1983 results assume that those agreeing with a statement would give one of the four highest scores possible: $10,9,8$, and 7 . These are consistent with Case B in the discussion associated with Table 3.5, Section 3.3. 
TABLE B.38. Overall Impressions of Energy Institutions by Prospect Group, Separate Tests $(a)$ for 1983 and 1985

\begin{tabular}{|c|c|c|c|}
\hline Item & $\begin{array}{l}\text { First-Tier } \\
\text { Prospects } \\
\end{array}$ & $\begin{array}{l}\text { Second-Tier } \\
\text { Prospects } \\
\end{array}$ & Nonprospects \\
\hline & $\%$ Ver & Favorable or & Favorable \\
\hline $\begin{array}{l}\text { Local electric utility } \\
1985 \\
1983\end{array}$ & $\begin{array}{l}79 \\
72\end{array}$ & $\begin{array}{l}72 \\
74\end{array}$ & $\begin{array}{l}73 \\
73\end{array}$ \\
\hline $\begin{array}{l}\text { Bonneville Power Administration } \\
1985 \\
1983\end{array}$ & $\begin{array}{l}65 \\
51\end{array}$ & $\begin{array}{l}55 \\
51\end{array}$ & $\begin{array}{l}55 \\
48\end{array}$ \\
\hline $\begin{array}{l}\text { Northwest Power Planning Council } \\
\quad 1985 \\
1983\end{array}$ & $\begin{array}{l}70 \\
40\end{array}$ & $\begin{array}{l}72 \\
51^{\star}\end{array}$ & $\begin{array}{l}61 \\
38 \sim\end{array}$ \\
\hline $\begin{array}{l}\text { State energy office } \\
1985 \\
1983\end{array}$ & $\begin{array}{l}78 \\
66\end{array}$ & $\begin{array}{l}73 \\
63\end{array}$ & $\begin{array}{l}63 \\
50 \sim\end{array}$ \\
\hline
\end{tabular}

(a) For the numbers of respondents used in these tests, see Table 6.4. Note that only those who were familiar with the specific institutions are used in computing the proportions. 
TABLE B.39. Believability of Energy Institutions as Sources of Energy Conservation Information by Prospect Group, Separate Tests $(a)$ for 1983 and 1985

\begin{tabular}{|c|c|c|c|}
\hline Item & $\begin{array}{l}\text { First-Tier } \\
\text { Prospects }\end{array}$ & $\begin{array}{l}\text { Second-Tier } \\
\text { Prospects }\end{array}$ & Nonprospects \\
\hline & $\%$ Very & 1 ievable or & l ievable \\
\hline $\begin{array}{l}\text { Local electric utility } \\
\quad 1985 \\
1983\end{array}$ & $\begin{array}{l}79 \\
92\end{array}$ & $\begin{array}{l}83^{*} \\
92\end{array}$ & $\begin{array}{l}70 \sim \\
85 \sim\end{array}$ \\
\hline $\begin{array}{l}\text { Bonneville Power Administration } \\
\quad 1985 \\
1983\end{array}$ & $\begin{array}{l}57 \\
79\end{array}$ & $\begin{array}{l}63 \\
82\end{array}$ & $\begin{array}{l}58 \\
69 \sim\end{array}$ \\
\hline $\begin{array}{l}\text { State energy office } \\
1985 \\
1983\end{array}$ & $\begin{array}{l}86 \\
86\end{array}$ & $\begin{array}{l}92^{\star} \\
89\end{array}$ & $\begin{array}{l}71 \sim \\
74 \sim\end{array}$ \\
\hline $\begin{array}{l}\text { Energy extension service } \\
1985 \\
1983\end{array}$ & $\begin{array}{r}100 \\
97\end{array}$ & $\begin{array}{l}95 \\
94\end{array}$ & $\begin{array}{l}84 \\
85 \sim\end{array}$ \\
\hline $\begin{array}{l}\text { Northwest Power Planning Council } \\
1985 \\
1983\end{array}$ & $\begin{array}{l}61 \\
77\end{array}$ & $\begin{array}{l}65 \\
80^{\star}\end{array}$ & $\begin{array}{l}70 \\
68 \sim\end{array}$ \\
\hline
\end{tabular}

(a) For the numbers of respondents used in these tests, see Table 6.5. Note that only those respondents who were familiar with the specific institutions are used in computing the proportions. 
TABLE B.40. Believability of Other Entities and Individuals as Sources of Energy Conservation Information By Prospect Group, Separate Tests for 1983 and 1985

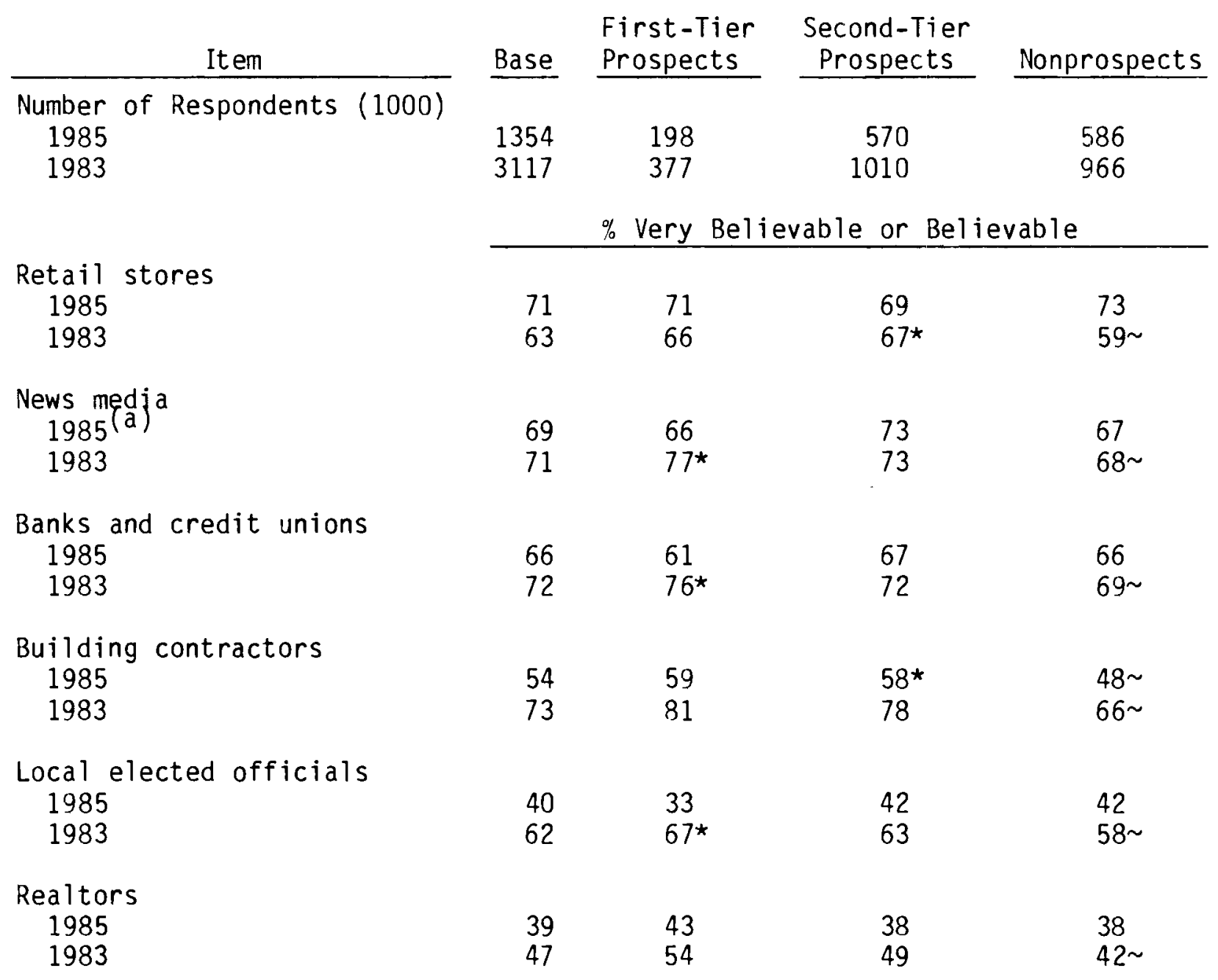

(a) Simple averages of radio, television, and newspapers. 
TABLE B.41. Preferred Methods for Conserving Energy By Prospect Groups, Separate Tests for 1983 and 1985

\begin{tabular}{|c|c|c|c|c|}
\hline Item & Base & $\begin{array}{l}\text { First-Tier } \\
\text { Prospects }\end{array}$ & $\begin{array}{c}\text { Second-Tier } \\
\text { Prospects } \\
\end{array}$ & Nonprospects \\
\hline $\begin{array}{l}\text { Number of Respondents (1000) } \\
1985 \\
1983\end{array}$ & $\begin{array}{l}2150 \\
3117\end{array}$ & $\begin{array}{l}309 \\
377\end{array}$ & $\begin{array}{r}955 \\
1010 \\
\text { Preferring } \\
\end{array}$ & $\begin{array}{l}886 \\
966\end{array}$ \\
\hline $\begin{array}{l}\text { Change way of living } \\
1985 \\
1983\end{array}$ & $\begin{array}{l}50 \\
52\end{array}$ & $\begin{array}{l}45 \\
50\end{array}$ & $\begin{array}{l}44 \\
49\end{array}$ & $\begin{array}{l}59 \star \\
55\end{array}$ \\
\hline $\begin{array}{l}\text { Spend money on improvements } \\
1985 \\
1983\end{array}$ & $\begin{array}{l}35 \\
30\end{array}$ & $\begin{array}{l}46 \\
31\end{array}$ & $\begin{array}{l}38 \\
30\end{array}$ & $\begin{array}{l}29 \sim \\
28\end{array}$ \\
\hline $\begin{array}{l}\text { Both } \\
1985 \\
1983\end{array}$ & $\begin{array}{l}10 \\
16\end{array}$ & $\begin{array}{r}9 \\
17\end{array}$ & $\begin{array}{l}15^{\star} \\
18^{\star}\end{array}$ & $\begin{array}{r}6 \sim \\
13 \sim\end{array}$ \\
\hline
\end{tabular}


TABLE B.42. No/Low Cost Energy Conservation Actions By Prospect Group, Separate Tests for 1983 and 1985

\begin{tabular}{|c|c|c|c|c|}
\hline Item & Base & $\begin{array}{l}\text { First-Tier } \\
\text { Prospects }\end{array}$ & $\begin{array}{l}\text { Second-Tier } \\
\text { Prospects }\end{array}$ & Nonprospects \\
\hline $\begin{array}{l}\text { Number of Respondents (1000) } \\
1985 \\
1983\end{array}$ & $\begin{array}{l}2150 \\
3117\end{array}$ & $\begin{array}{r}309 \\
377 \\
\% \text { Regl } \\
\end{array}$ & $\begin{array}{r}955 \\
1010 \\
\text { arly Practici } \\
\end{array}$ & $\begin{array}{l}386 \\
966\end{array}$ \\
\hline $\begin{array}{l}\text { Control lights with } \\
\text { dimmer switches } \\
1985 \\
1983\end{array}$ & $\begin{array}{l}47 \\
49\end{array}$ & $\begin{array}{l}42 \\
57\end{array}$ & $\begin{array}{l}50 \\
50\end{array}$ & $\begin{array}{l}45 \\
44 \sim\end{array}$ \\
\hline $\begin{array}{l}\text { Lower thermostat setting } \\
1985 \\
1983\end{array}$ & $\begin{array}{l}83 \\
86\end{array}$ & $\begin{array}{l}92 \# \\
86\end{array}$ & $\begin{array}{l}84 \# \\
83\end{array}$ & $\begin{array}{l}77 \# \\
76 \sim\end{array}$ \\
\hline $\begin{array}{l}\text { Select energy efficient } \\
\text { appliances } \\
1985 \\
1983\end{array}$ & $\begin{array}{l}63 \\
74\end{array}$ & $\begin{array}{l}71 \\
84 \#\end{array}$ & $\begin{array}{l}66 \\
77 \#:\end{array}$ & $\begin{array}{l}56 \sim \\
67 \#\end{array}$ \\
\hline $\begin{array}{l}\text { Use shades for heating } \\
\text { and cooling } \\
1985 \\
1983\end{array}$ & $\begin{array}{l}89 \\
88\end{array}$ & $\begin{array}{l}92 \\
91\end{array}$ & $\begin{array}{l}89 \\
92\end{array}$ & $\begin{array}{l}88 \\
83 \sim\end{array}$ \\
\hline $\begin{array}{l}\text { Install water flow } \\
\text { restrictors } \\
1985 \\
1983\end{array}$ & $\begin{array}{l}37 \\
38\end{array}$ & $\begin{array}{l}45 \\
44\end{array}$ & $\begin{array}{l}40 \\
41\end{array}$ & $\begin{array}{l}29 \sim \\
33 \sim\end{array}$ \\
\hline $\begin{array}{l}\text { Put plastic over windows } \\
1985 \\
1983\end{array}$ & $\begin{array}{l}27 \\
67\end{array}$ & $\begin{array}{l}36 * \\
65\end{array}$ & $\begin{array}{l}24 \sim \\
67\end{array}$ & $\begin{array}{l}27 \\
69\end{array}$ \\
\hline $\begin{array}{l}\text { Receive an energy audit } \\
1985 \\
1983\end{array}$ & $\begin{array}{l}32 \\
30\end{array}$ & $\begin{array}{l}29 \\
32\end{array}$ & $\begin{array}{l}37^{\star} \\
34\end{array}$ & $\begin{array}{l}28 \sim \\
25 \sim\end{array}$ \\
\hline $\begin{array}{l}\text { Wrap water heater } \\
\qquad \begin{array}{l}1985 \\
1983\end{array}\end{array}$ & $\begin{array}{l}65 \\
64\end{array}$ & $\begin{array}{l}67 \\
72\end{array}$ & $\begin{array}{l}70^{*} \\
66\end{array}$ & $\begin{array}{l}58 \sim \\
59 \sim\end{array}$ \\
\hline
\end{tabular}


TABLE B.43. Proportions of Home Equipped with Specific Energy Conservation Measures By Prospect Group, Separate Tests for 1983 and 1985

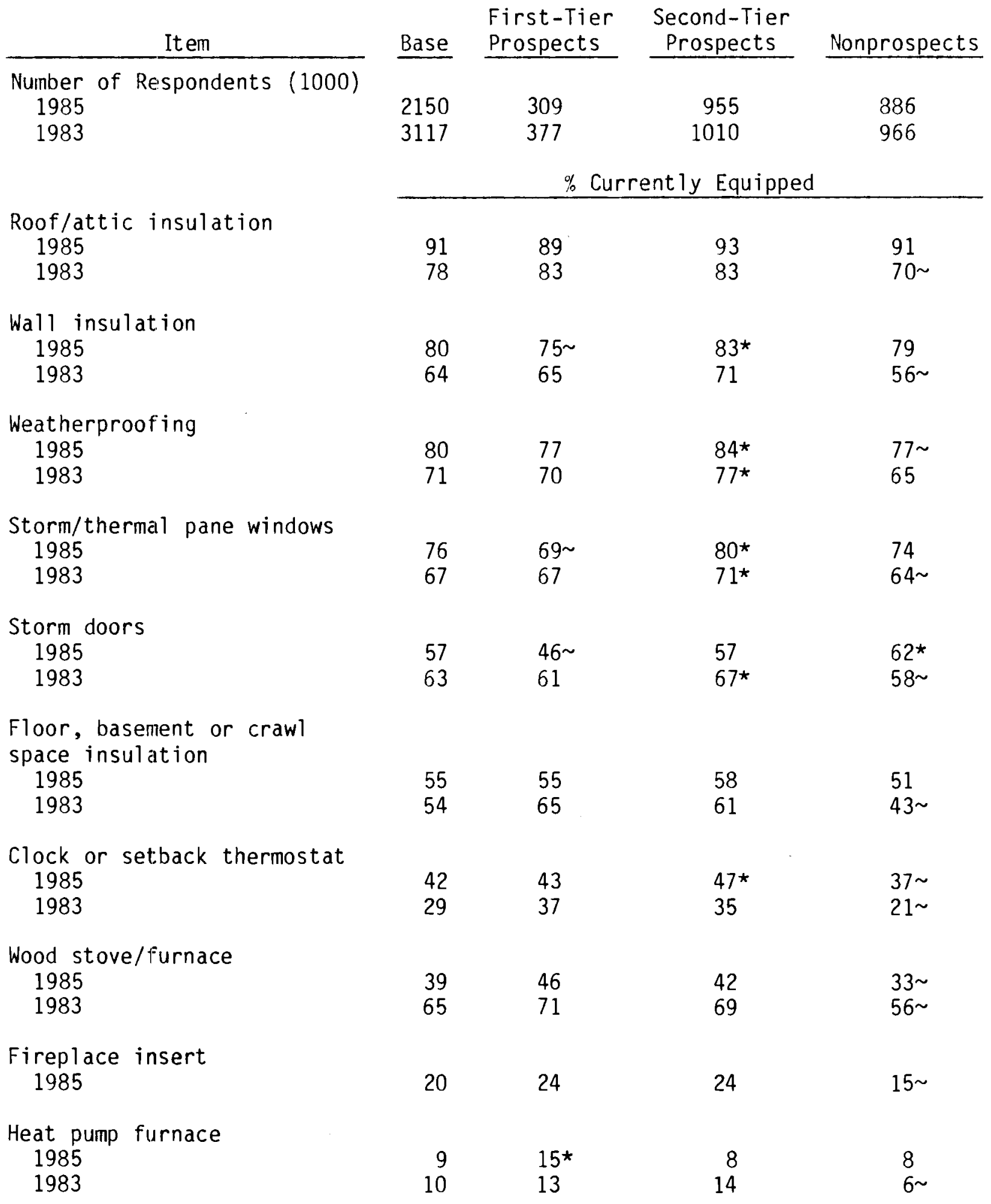



TABLE B.44. Sources of Financing Conservation Investment, Separate Tests for

\begin{tabular}{|c|c|c|c|c|}
\hline Item & Base & $\begin{array}{l}\text { First-Tier } \\
\text { Prospects } \\
\end{array}$ & $\begin{array}{l}\text { Second-Tier } \\
\text { Prospects } \\
\end{array}$ & Nonprospects \\
\hline $\begin{array}{l}\text { Number of Respondents (1000) } \\
1985 \\
1983\end{array}$ & $\begin{array}{l}2150 \\
2227\end{array}$ & $\begin{array}{l}309 \\
377\end{array}$ & $\begin{array}{r}955 \\
1010 \\
\% \\
\end{array}$ & $\begin{array}{l}885 \\
966\end{array}$ \\
\hline $\begin{array}{l}\text { Current Income } \\
1985 \\
1983\end{array}$ & $\begin{array}{l}51 \\
75\end{array}$ & $\begin{array}{l}55 \\
74\end{array}$ & $\begin{array}{l}51 \\
77\end{array}$ & $\begin{array}{l}50 \\
75\end{array}$ \\
\hline $\begin{array}{l}\text { Savings } \\
1985 \\
1983\end{array}$ & $\begin{array}{l}15 \\
38\end{array}$ & $\begin{array}{l}16 \\
39\end{array}$ & $\begin{array}{l}14 \\
41^{\star}\end{array}$ & $\begin{array}{l}17 \\
35 \sim\end{array}$ \\
\hline $\begin{array}{l}\text { Delay or Cut Back Other } \\
\text { Purchases } \\
1985 \\
1983\end{array}$ & $\begin{array}{r}1 \\
48\end{array}$ & $\begin{array}{c}1 \\
69 \#\end{array}$ & $\begin{array}{c}1 \\
50 \#\end{array}$ & $\frac{1}{36 \#}$ \\
\hline $\begin{array}{l}\text { Bank Loans and Credits } \\
1985 \\
1983\end{array}$ & $\begin{array}{r}7 \\
13\end{array}$ & $\begin{array}{c}6 \\
18^{\star}\end{array}$ & $\begin{array}{l}9 * \\
13\end{array}$ & $\begin{array}{r}4 \sim \\
12 \sim\end{array}$ \\
\hline $\begin{array}{l}\text { Utility Loan } \\
1985 \\
1983\end{array}$ & $\begin{array}{l}2 \\
8\end{array}$ & $\begin{array}{r}2 \\
10\end{array}$ & $\begin{array}{l}2 \\
8\end{array}$ & $\begin{array}{l}2 \\
7\end{array}$ \\
\hline $\begin{array}{l}\text { Payments by Utility } \\
1985 \\
1983\end{array}$ & $\begin{array}{l}3 \\
9\end{array}$ & $\begin{array}{r}1 \\
11\end{array}$ & $\begin{array}{l}3 \\
9\end{array}$ & $\begin{array}{l}3 \\
8\end{array}$ \\
\hline $\begin{array}{l}\text { Paid by Others } \\
1985\end{array}$ & 0 & 1 & 1 & 0 \\
\hline $\begin{array}{l}\text { Federal Tax Credits } \\
1985 \\
1983\end{array}$ & $\begin{array}{r}0 \\
23\end{array}$ & $\begin{array}{c}0 \\
30 *\end{array}$ & $\begin{array}{r}0 \\
23\end{array}$ & $\begin{array}{c}1 \\
19 \sim\end{array}$ \\
\hline $\begin{array}{l}\text { Combined Sources } \\
\quad 1985\end{array}$ & 1 & 0 & 2 & 1 \\
\hline $\begin{array}{l}\text { Other } \\
1985\end{array}$ & 0 & 1 & 0 & 0 \\
\hline
\end{tabular}

(a) 1983 data include, while 1985 data do not include, multiple mentions. 
TABLE B.45. Likely Installation of Energy Conservation Measures by Prospect Group, Separate Tests for 1983 and 1985

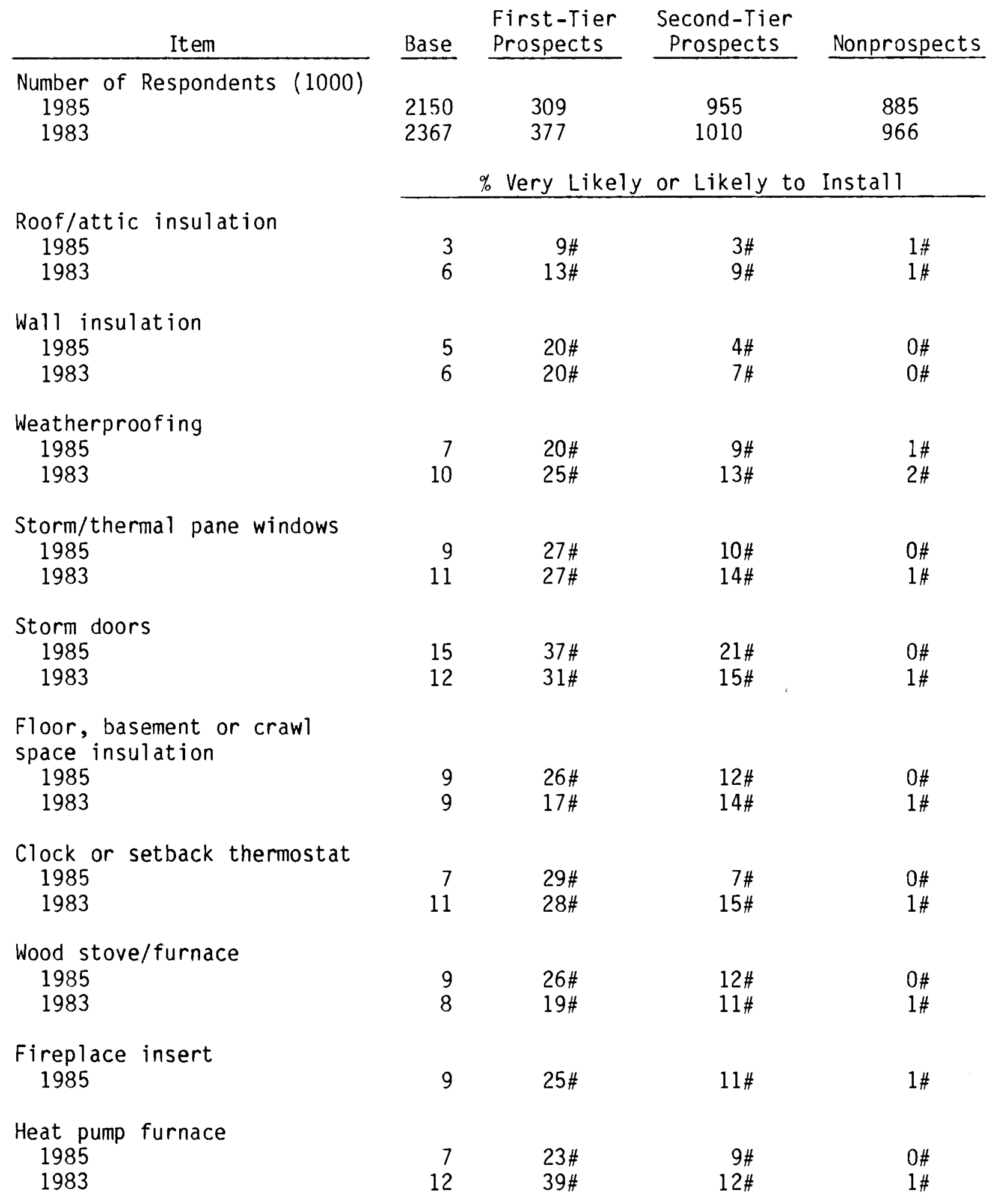


,

4 


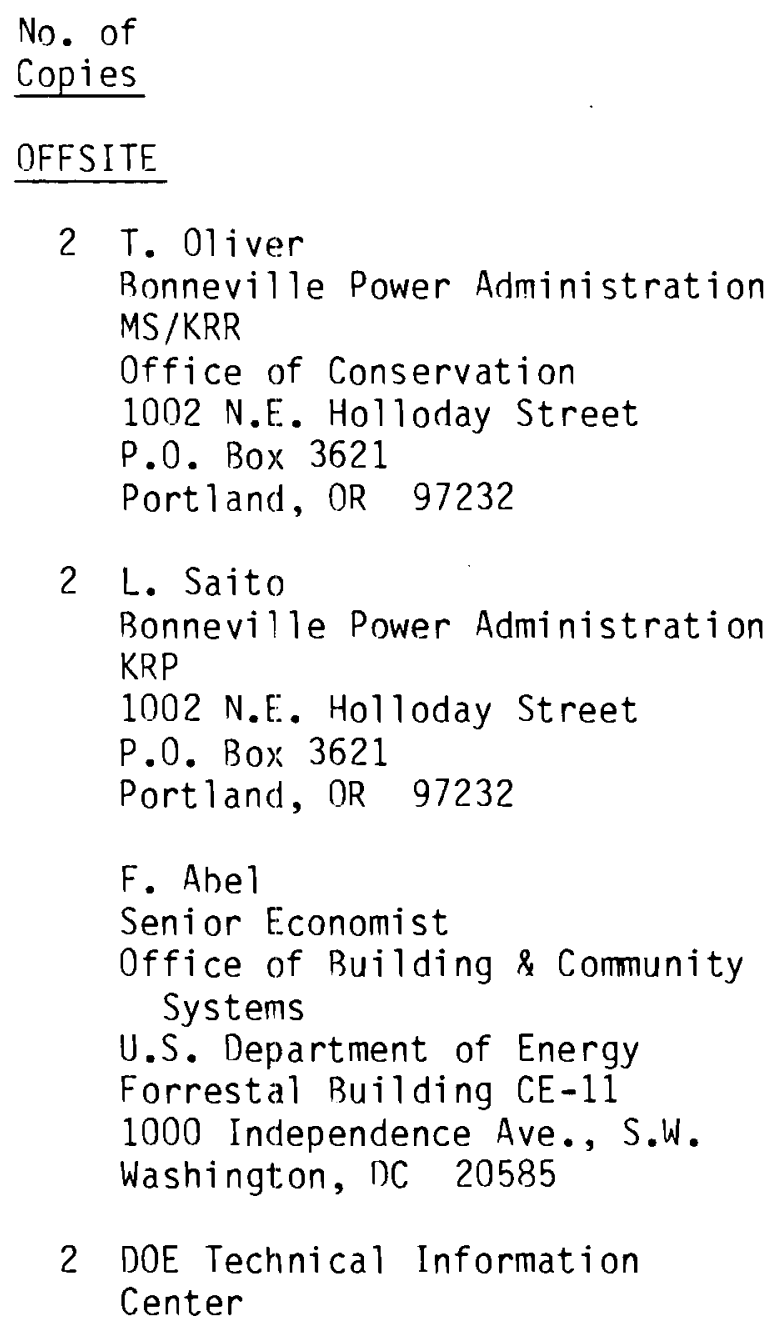

2 DOE Technical Information Center

No. of

Copies

DNSITE

DOE Richland Operations Office

J. J. Sutey

24 Pacific Northwest Laboratory

D. L. Ivey (10)

B. M. Railey

M. P. Hattrup

R. T. Nordi

S. A. Shankle

B. L. Mohler

J. M. Fang

J. Callaway

Publishing Coordination MH (2)

Technical Report Files (5) 
- 